\title{
Synthesis and characterization of electrophilic group 4 metal complexes of benzynes
}

\author{
Shawn Michael Nettles \\ West Virginia University
}

Follow this and additional works at: https://researchrepository.wvu.edu/etd

\section{Recommended Citation}

Nettles, Shawn Michael, "Synthesis and characterization of electrophilic group 4 metal complexes of benzynes" (1998). Graduate Theses, Dissertations, and Problem Reports. 925.

https://researchrepository.wvu.edu/etd/925

This Thesis is protected by copyright and/or related rights. It has been brought to you by the The Research Repository @ WVU with permission from the rights-holder(s). You are free to use this Thesis in any way that is permitted by the copyright and related rights legislation that applies to your use. For other uses you must obtain permission from the rights-holder(s) directly, unless additional rights are indicated by a Creative Commons license in the record and/ or on the work itself. This Thesis has been accepted for inclusion in WVU Graduate Theses, Dissertations, and Problem Reports collection by an authorized administrator of The Research Repository @ WVU. For more information, please contact researchrepository@mail.wvu.edu. 


\title{
SYNTHESIS AND CHARACTERIZATION OF ELECTROPHILIC GROUP 4 METAL COMPLEXES OF BENZYNES
}

\section{By}

Shawn M. Nettles

\author{
THESIS \\ Submitted to \\ The College of Arts and Sciences \\ at \\ West Virginia University \\ in partial fulfillment of the requirements \\ for the degree of \\ Master of Science \\ in \\ Chemistry
}

Department of Chemistry

Morgantown, West Virginia

1998

Keywords: Benzynes, Metallacycles, Titanium, Zirconium 


\section{Acknowledgments}

I would like to thank my research advisor, Dr. Jeffrey L. Petersen, whose leadership by example and strong work ethic has motivated me over the past three years. His guidance and assistance made the completion of this thesis possible. I would also like to express my appreciation toward the faculty and staff for their assistance.

I would like to thank my co-worker, Paul Kletzly, who worked with me for three years and helped make the entire laboratory experience more enjoyable and even humorous at times. I would also like to thank Lioba Kloppenburg for her assistance during the beginning of my graduate career.

The friends that I have made at this university and Morgantown itself have and will always have a lasting memory in my mind. I thank them for providing me with laughs during the good times and support when times were tough.

Outside of the work environment, I would like to thank my family and friends that stood by me throughout my effort. Finally, I would like to thank my parents, Bob and Sandy Nettles, and my grandparents, Willard and Evelyn Starkey, for guiding me to the person I am and helping me to visualize the person I want to become. Their encouragement and support has helped me in establishing and meeting my goals. 


\section{Table of Contents}

Title Page $\quad$ i

Acknowledgments $\quad$ ii

Table of Contents $\quad$ iii

List of Tables $\quad$ vi

List of Figures vii

Introduction 1

Experimental 14

Reagents 14

$\begin{array}{ll}\text { Instrumentation } & 14\end{array}$

$\begin{array}{ll}\text { General Procedures } & 15\end{array}$

$\begin{array}{ll}\text { Synthesis of Compounds } & 15\end{array}$

Preparation of $\left(\mathrm{C}_{5} \mathrm{H}_{5}\right) \mathrm{SiMe}_{2}(\mathrm{~N}(\mathrm{H})-\mathrm{t}-\mathrm{Bu}) \quad 15$

(a) Preparation of $\left(\mathrm{C}_{5} \mathrm{H}_{5}\right) \mathrm{SiMe}_{2} \mathrm{Cl} 16$

(b) Preparation of $\left(\mathrm{C}_{5} \mathrm{H}_{5}\right) \mathrm{SiMe}_{2}(\mathrm{~N}(\mathrm{H})-\mathrm{t}-\mathrm{Bu}) \quad 16$

Preparation of $\left(\mathrm{C}_{5} \mathrm{Me}_{4} \mathrm{H}\right) \mathrm{SiMe}_{2}(\mathrm{~N}(\mathrm{H})-\mathrm{t}-\mathrm{Bu}) \quad 17$

(a) Preparation of $\left(\mathrm{C}_{5} \mathrm{Me}_{4} \mathrm{H}\right) \mathrm{SiMe}_{2} \mathrm{Cl} \quad 17$

(b) Preparation of $\left(\mathrm{C}_{5} \mathrm{Me}_{4} \mathrm{H}\right) \mathrm{SiMe}_{2}(\mathrm{~N}(\mathrm{H})-\mathrm{t}-\mathrm{Bu}) \quad 17$

$\begin{array}{ll}\text { Synthesis of } \mathrm{M}\left(\mathrm{NMe}_{2}\right)_{4} & 18\end{array}$

(a) Preparation of $\mathrm{Ti}\left(\mathrm{NMe}_{2}\right)_{4} \quad 18$

(b) Preparation of $\mathrm{Zr}\left(\mathrm{NMe}_{2}\right)_{4} \quad 18$

Synthesis of $\left[\left(\mathrm{C}_{5} \mathrm{R}_{4}\right) \mathrm{SiMe}_{2}(\mathrm{~N}-\mathrm{t}-\mathrm{Bu})\right] \mathrm{M}\left(\mathrm{NMe}_{2}\right)_{2}, \mathrm{R}=\mathrm{H}, \mathrm{Me} ; \mathrm{M}=\mathrm{Ti}, \mathrm{Zr}$ $\begin{array}{ll}\text { via Amine Elimination } & 19\end{array}$

(a) Preparation of $\left[\left(\mathrm{C}_{5} \mathrm{H}_{4}\right) \mathrm{SiMe}_{2}(\mathrm{~N}-\mathrm{t}-\mathrm{Bu})\right] \mathrm{Ti}\left(\mathrm{NMe}_{2}\right)_{2} \quad 19$

(b) Preparation of $\left[\left(\mathrm{C}_{5} \mathrm{H}_{4}\right) \mathrm{SiMe}_{2}(\mathrm{~N}-\mathrm{t}-\mathrm{Bu})\right] \mathrm{Zr}\left(\mathrm{NMe}_{2}\right)_{2} \quad 19$

(c) Preparation of $\left[\left(\mathrm{C}_{5} \mathrm{Me}_{4}\right) \mathrm{SiMe}_{2}(\mathrm{~N}-\mathrm{t}-\mathrm{Bu})\right] \mathrm{Zr}\left(\mathrm{NMe}_{2}\right)_{2} \quad 20$ 
Conversion of $\left[\left(\mathrm{C}_{5} \mathrm{R}_{4}\right) \mathrm{SiMe}_{2}(\mathrm{~N}-\mathrm{t}-\mathrm{Bu})\right] \mathrm{M}\left(\mathrm{NMe}_{2}\right)_{2},(\mathrm{R}=\mathrm{H}, \mathrm{Me}$;

$\mathrm{M}=\mathrm{Ti}, \mathrm{Zr}$ ), to Dichloride $\quad 20$

(a) Synthesis of $\left[\left(\mathrm{C}_{5} \mathrm{H}_{4}\right) \mathrm{SiMe}_{2}(\mathrm{~N}-\mathrm{t}-\mathrm{Bu})\right] \mathrm{TiCl}_{2}$

(b) Synthesis of $\left\{\left[\left(\mathrm{C}_{5} \mathrm{H}_{4}\right) \mathrm{SiMe}_{2}(\mathrm{~N}-\mathrm{t}-\mathrm{Bu})\right] \mathrm{ZrCl}(\mu-\mathrm{Cl})\right\}_{2}$

(c) Synthesis of $\left[\left(\mathrm{C}_{5} \mathrm{Me}_{4}\right) \mathrm{SiMe}_{2}(\mathrm{~N}-\mathrm{t}-\mathrm{Bu})\right] \mathrm{ZrCl}_{2}$

Preparation of Diphenyl Derivatives 22

(a) Synthesis of $\left[\left(\mathrm{C}_{5} \mathrm{H}_{4}\right) \mathrm{SiMe}_{2}(\mathrm{~N}-\mathrm{t}-\mathrm{Bu})\right] \mathrm{Ti}\left(\mathrm{C}_{6} \mathrm{H}_{5}\right)_{2}$

(b) Synthesis of $\left[\left(\mathrm{C}_{5} \mathrm{H}_{4}\right) \mathrm{SiMe}_{2}(\mathrm{~N}-\mathrm{t}-\mathrm{Bu})\right] \mathrm{Zr}\left(\mathrm{C}_{6} \mathrm{H}_{5}\right)_{2}$

(c) Synthesis of $\left[\left(\mathrm{C}_{5} \mathrm{Me}_{4}\right) \mathrm{SiMe}_{2}(\mathrm{~N}-\mathrm{t}-\mathrm{Bu})\right] \mathrm{Zr}\left(\mathrm{C}_{6} \mathrm{H}_{5}\right)_{2}$

Diphenylacetylene Coupling Reactions 24

(a) Synthesis of $\left[\left(\mathrm{C}_{5} \mathrm{H}_{4}\right) \mathrm{SiMe}_{2}(\mathrm{~N}-\mathrm{t}-\mathrm{Bu})\right] \mathrm{Ti}\left[\left(\mathrm{C}_{6} \mathrm{H}_{4}\right) \mathrm{C}(\mathrm{Ph})=\mathrm{C}(\mathrm{Ph})\right]$

(b) Synthesis of $\left[\left(\mathrm{C}_{5} \mathrm{Me}_{4}\right) \mathrm{SiMe}_{2}(\mathrm{~N}-\mathrm{t}-\mathrm{Bu})\right] \mathrm{Zr}\left[\left(\mathrm{C}_{6} \mathrm{H}_{4}\right) \mathrm{C}(\mathrm{Ph})=\mathrm{C}(\mathrm{Ph})\right] \quad 25$

X-ray Structural Analysis of

$\left[\left(\mathrm{C}_{5} \mathrm{H}_{4}\right) \mathrm{SiMe}_{2}(\mathrm{~N}-\mathrm{t}-\mathrm{Bu})\right] \mathrm{Ti}\left[\left(\mathrm{C}_{6} \mathrm{H}_{4}\right) \mathrm{C}(\mathrm{Ph})=\mathrm{C}(\mathrm{Ph})\right] \quad 28$

Results and Discussion 33

Preparation of $\left[\left(\mathrm{C}_{5} \mathrm{R}_{4}\right) \mathrm{SiMe}_{2}(\mathrm{~N}-\mathrm{t}-\mathrm{Bu})\right] \mathrm{M}\left(\mathrm{C}_{6} \mathrm{H}_{5}\right)_{2}$,

$\mathrm{R}=\mathrm{H}, \mathrm{Me} ; \mathrm{M}=\mathrm{Ti}, \mathrm{Zr}$

(a) Synthesis of $\left[\left(\mathrm{C}_{5} \mathrm{H}_{4}\right) \mathrm{SiMe}_{2}(\mathrm{~N}-\mathrm{t}-\mathrm{Bu})\right] \mathrm{Ti}\left(\mathrm{C}_{6} \mathrm{H}_{5}\right)_{2}$

(b) Synthesis of $\left[\left(\mathrm{C}_{5} \mathrm{H}_{4}\right) \mathrm{SiMe}_{2}(\mathrm{~N}-\mathrm{t}-\mathrm{Bu})\right] \mathrm{Zr}\left(\mathrm{C}_{6} \mathrm{H}_{5}\right)_{2}$

(c) Synthesis of $\left[\left(\mathrm{C}_{5} \mathrm{Me}_{4}\right) \mathrm{SiMe}_{2}(\mathrm{~N}-\mathrm{t}-\mathrm{Bu})\right] \mathrm{Zr}\left(\mathrm{C}_{6} \mathrm{H}_{5}\right)_{2}$

Diphenylacetylene Coupling Reactions 40

(a) Synthesis of $\left[\left(\mathrm{C}_{5} \mathrm{H}_{4}\right) \mathrm{SiMe}_{2}(\mathrm{~N}-\mathrm{t}-\mathrm{Bu})\right] \mathrm{Ti}\left[\left(\mathrm{C}_{6} \mathrm{H}_{4}\right) \mathrm{C}(\mathrm{Ph})=\mathrm{C}(\mathrm{Ph})\right] \quad 40$

(b) Synthesis of $\left[\left(\mathrm{C}_{5} \mathrm{Me}_{4}\right) \mathrm{SiMe}_{2}(\mathrm{~N}-\mathrm{t}-\mathrm{Bu})\right] \mathrm{Zr}\left[\left(\mathrm{C}_{6} \mathrm{H}_{4}\right) \mathrm{C}(\mathrm{Ph})=\mathrm{C}(\mathrm{Ph})\right] \quad 48$

Description of the Molecular Structure of

$\left[\left(\mathrm{C}_{5} \mathrm{H}_{4}\right) \mathrm{SiMe}_{2}(\mathrm{~N}-\mathrm{t}-\mathrm{Bu})\right] \mathrm{Ti}\left[\left(\mathrm{C}_{6} \mathrm{H}_{4}\right) \mathrm{C}(\mathrm{Ph})=\mathrm{C}(\mathrm{Ph})\right]$

Concluding Remarks $\quad 60$

$\begin{array}{ll}\text { References } & 62\end{array}$ 
$\begin{array}{ll}\text { Abstract } & 65\end{array}$

$\begin{array}{ll}\text { Vita } & 66\end{array}$

$\begin{array}{ll}\text { Approval Page } & 67\end{array}$ 


\section{List of Tables}

Table

1

${ }^{1} \mathrm{H}$ and ${ }^{13} \mathrm{C}$ NMR data for

$\left[\left(\mathrm{C}_{5} \mathrm{H}_{4}\right) \mathrm{SiMe}_{2}(\mathrm{~N}-\mathrm{t}-\mathrm{Bu})\right] \mathrm{Ti}\left[\left(\mathrm{C}_{6} \mathrm{H}_{4}\right) \mathrm{C}(\mathrm{Ph})=\mathrm{C}(\mathrm{Ph})\right]$.

26

$2 \quad{ }^{1} \mathrm{H}$ and ${ }^{13} \mathrm{C} \mathrm{NMR}$ data for

$\left[\left(\mathrm{C}_{5} \mathrm{Me}_{4}\right) \mathrm{SiMe}_{2}(\mathrm{~N}-\mathrm{t}-\mathrm{Bu})\right] \mathrm{Zr}\left[\left(\mathrm{C}_{6} \mathrm{H}_{4}\right) \mathrm{C}(\mathrm{Ph})=\mathrm{C}(\mathrm{Ph})\right]$.

27

3 Crystallographic Data for the Structural Analysis of

$\left[\left(\mathrm{C}_{5} \mathrm{H}_{4}\right) \operatorname{SiMe}_{2}(\mathrm{~N}-\mathrm{t}-\mathrm{Bu})\right] \mathrm{Ti}\left(\mathrm{C}_{6} \mathrm{H}_{4} \mathrm{C}(\mathrm{Ph})=\mathrm{C}(\mathrm{Ph})\right]$.

30

4 Interatomic Distances $(\AA)$ and Bond Angles for $\left[\left(\mathrm{C}_{5} \mathrm{H}_{4}\right) \mathrm{SiMe}_{2}(\mathrm{~N}-\mathrm{t}-\mathrm{Bu})\right] \mathrm{Ti}\left(\mathrm{C}_{6} \mathrm{H}_{4} \mathrm{C}(\mathrm{Ph})=\mathrm{C}(\mathrm{Ph})\right]$.

${ }^{13} \mathrm{C} \mathrm{NMR}$ data for $\left[\left(\mathrm{C}_{5} \mathrm{H}_{4}\right) \operatorname{SiMe}_{2}(\mathrm{~N}-\mathrm{t}-\mathrm{Bu})\right] \mathrm{Ti}\left(\mathrm{C}_{6} \mathrm{H}_{5}\right)_{2}$.

35

${ }^{13} \mathrm{C}$ NMR data for $\left[\left(\mathrm{C}_{5} \mathrm{H}_{4}\right) \mathrm{SiMe}_{2}(\mathrm{~N}-\mathrm{t}-\mathrm{Bu})\right] \mathrm{Zr}\left(\mathrm{C}_{6} \mathrm{H}_{5}\right)_{2}$.

37

7

${ }^{13} \mathrm{C} \mathrm{NMR}$ data for $\left[\left(\mathrm{C}_{5} \mathrm{Me}_{4}\right) \mathrm{SiMe}_{2}(\mathrm{~N}-\mathrm{t}-\mathrm{Bu})\right] \mathrm{Zr}\left(\mathrm{C}_{6} \mathrm{H}_{5}\right)_{2}$.

39 


\section{List of Figures}

Figure Page

1 Diagram of benzyne. 2

2 Molecular structure of $\mathrm{Ta}\left(\eta^{5}-\mathrm{C}_{5} \mathrm{Me}_{5}\right)\left(\mathrm{C}_{6} \mathrm{H}_{4}\right) \mathrm{Me}_{2}$. 6

3 Molecular structure of trimethylphosphine adduct

$\begin{array}{ll}\text { of the zirconocene-benzyne complex. } & 7\end{array}$

$4 \quad$ Structures of group 4 metallocene and ansa-

monocyclopentadienyl amido metal complexes. $\quad 9$

5 Coupling reaction of $\left[\left(\mathrm{C}_{5} \mathrm{H}_{4}\right) \mathrm{SiMe}_{2}(\mathrm{~N}-\mathrm{t}-\mathrm{Bu})\right] \mathrm{Ti}\left(\mathrm{C}_{6} \mathrm{H}_{5}\right)_{2}$

with diphenylacetylene.

62 2D COSY NMR spectrum for

$\left[\left(\mathrm{C}_{5} \mathrm{H}_{4}\right) \mathrm{SiMe}_{2}(\mathrm{~N}-\mathrm{t}-\mathrm{Bu})\right] \mathrm{Ti}\left[\left(\mathrm{C}_{6} \mathrm{H}_{4}\right) \mathrm{C}(\mathrm{Ph})=\mathrm{C}(\mathrm{Ph})\right]$.

7 2D HETCOR NMR spectrum measured for

$\left[\left(\mathrm{C}_{5} \mathrm{H}_{4}\right) \mathrm{SiMe}_{2}(\mathrm{~N}-\mathrm{t}-\mathrm{Bu})\right] \mathrm{Ti}\left[\left(\mathrm{C}_{6} \mathrm{H}_{4}\right) \mathrm{C}(\mathrm{Ph})=\mathrm{C}(\mathrm{Ph})\right]$.

8 Coupling reaction of

$\left[\left(\mathrm{C}_{5} \mathrm{Me}_{4}\right) \mathrm{SiMe}_{2}(\mathrm{~N}-\mathrm{t}-\mathrm{Bu})\right] \mathrm{Zr}\left(\mathrm{C}_{6} \mathrm{H}_{5}\right)_{2}$

with diphenylacetylene.

9 2D COSY NMR spectrum for

$\left[\left(\mathrm{C}_{5} \mathrm{Me}_{4}\right) \mathrm{SiMe}_{2}(\mathrm{~N}-\mathrm{t}-\mathrm{Bu})\right] \mathrm{Zr}\left[\left(\mathrm{C}_{6} \mathrm{H}_{4}\right) \mathrm{C}(\mathrm{Ph})=\mathrm{C}(\mathrm{Ph})\right]$.

10 2D HETCOR NMR spectrum measured for

$\left[\left(\mathrm{C}_{5} \mathrm{Me}_{4}\right) \mathrm{SiMe}_{2}(\mathrm{~N}-\mathrm{t}-\mathrm{Bu})\right] \mathrm{Zr}\left[\left(\mathrm{C}_{6} \mathrm{H}_{4}\right) \mathrm{C}(\mathrm{Ph})=\mathrm{C}(\mathrm{Ph})\right]$.

11 Perspective view of the molecular structure of $\left[\left(\mathrm{C}_{5} \mathrm{H}_{4}\right) \mathrm{SiMe}_{2}(\mathrm{~N}-\mathrm{t}-\mathrm{Bu})\right] \mathrm{Ti}\left[\left(\mathrm{C}_{6} \mathrm{H}_{4}\right) \mathrm{C}(\mathrm{Ph})=\mathrm{C}(\mathrm{Ph})\right]$ with the non-hydrogen atom labeling scheme. 


\section{Introduction}

\section{Benzyne}

Transition metals have the ability to stabilize organic fragments that are highly reactive or unknown in the free state. Examples of these organic fragments include cyclobutadiene, ${ }^{1}$ trimethylenemethane, ${ }^{2}$ carbenes, $^{3}$ small ring acetylenes, ${ }^{4}$ and benzyne. ${ }^{5}$

Benzyne, sometimes called dehydrobenzene, ${ }^{6}$ has not been isolated in the free state under ordinary conditions but has been observed spectroscopically in an inert matrix at very low temperatures. ${ }^{7}$ Benzyne exists as a highly unstable reaction intermediate in the elimination-addition mechanism for nucleophilic aromatic substitution, shown in equation 1.

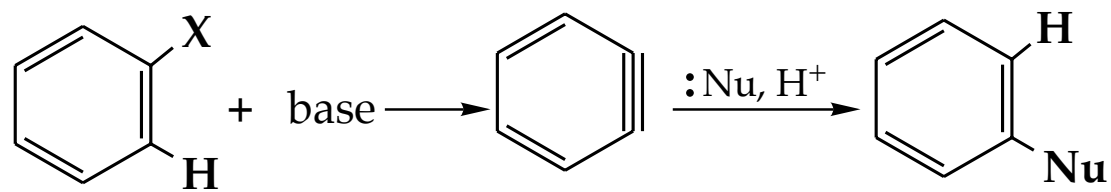

(eq. 1)

There have been several representations of the bonding in benzyne. The bonding representation most generally used describes benzyne as a benzene ring with two adjacent hydrogen atoms removed. With the removal of these two hydrogen atoms, a bond in the plane of the ring is formed by the overlap of the two $\mathrm{sp}^{2}$ orbitals, as shown in Figure 1. These two $\mathrm{sp}^{2}$ orbitals are orthogonal to the $\pi$-molecular orbitals of the ring and are directed away from each other with reduced overlap. Unless the system departs from planarity, the interaction between these orbitals is weak, resulting in a more reactive bond. 


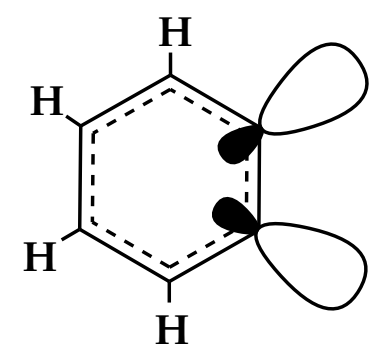

Figure 1. Diagram of benzyne.

Spectroscopic analysis gives a bond length of $1.35 \AA$ for the "triple bond" in benzyne, which is about $0.05 \AA$ shorter than the normal benzene carboncarbon bond length. ${ }^{8}$

\section{Organometallic Benzyne}

As early as 1968, ${ }^{9}$ unusual reactivity of group 4 diarylmetallocene derivatives was noted. Refluxing diphenyltitanocene with diphenylacetylene in benzene led to a loss of a molecule of benzene and the formation of a new titanium metallacycle (eq. 2). Years later, $V_{\text {ol' }} \operatorname{pin}^{10}$ reacted carbon dioxide

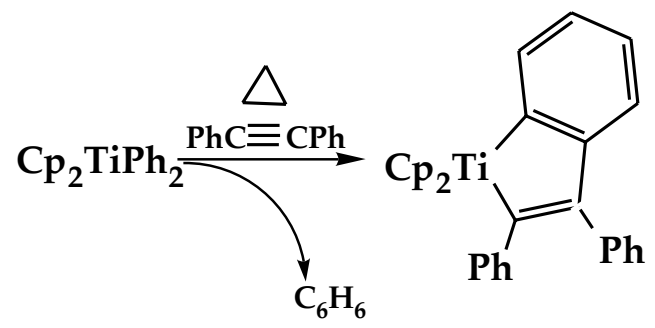

with diphenyltitanocene to form a five membered metallacycle, shown in equation 3. It was here where the titanocene-benzyne intermediate was

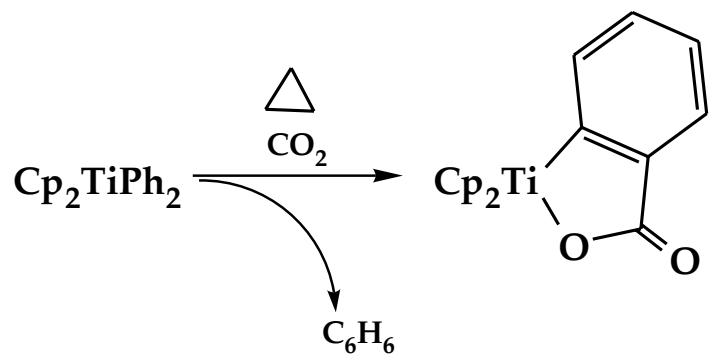


was proposed. Subsequent investigations by Teuben ${ }^{11}$ and coworkers with deuterated compounds and solvents showed that upon thermolysis of diphenyltitanocene, deuterium labels were scrambled between the phenyl ligands, the cyclopentadienyl ligands, and the solvent. Although several studies of the thermal decomposition of alkyl- and aryldicyclopentadienyltitanium compounds were carried out, the nature of the mechanism of the thermolysis reaction remained uncertain.

In the late 1970's, Erker ${ }^{12}$ and his co-workers investigated the thermal stability of diphenyl- and ditolylzirconocene derivatives and demonstrated the intermediacy of a benzyne complex. Up to this point, the hydrocarbons solvents used for the thermolysis of diphenyltitanocene and related systems were assumed to "merely act as solvents and did not participate in the reaction. ${ }^{13 "}$ Erker investigated the validity of this statement through a study of the thermolysis of diarylzirconocenes in aromatic hydrocarbon solvents. Their studies consisted of heating different diarylzirconocenes in aromatic hydrocarbon solvents and then analyzing the product mixture by photochemical degradation to form biphenyls. The photolysis did not affect the $\eta^{5}$-cyclopentadienyl ligands and only selectively coupled the $\sigma$-bonded aryl groups to form biphenyls, as shown in eq. 4. Following photolysis, the biphenyls were separated using gas-liquid chromatography.

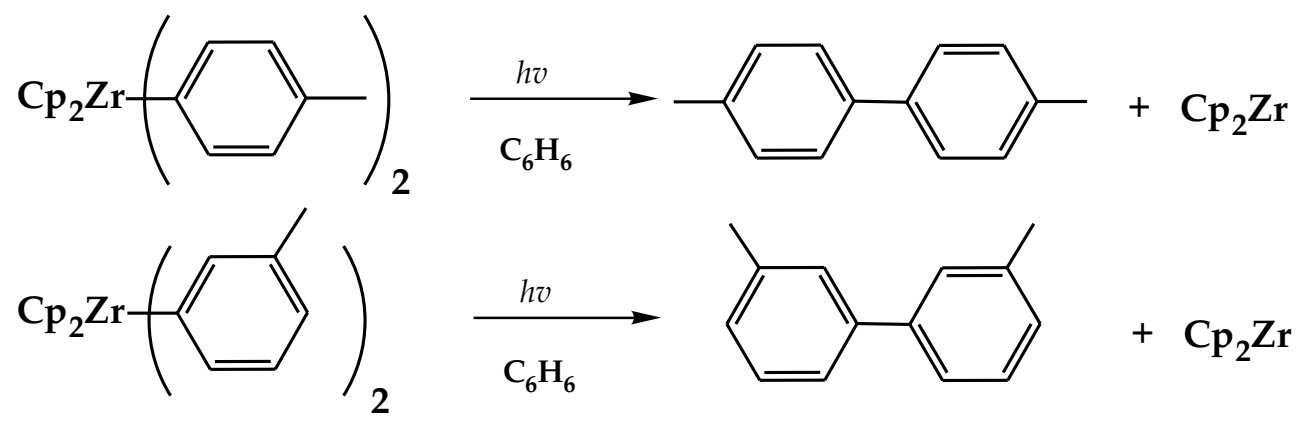


From identification of the biphenyls, the question as to whether or not the aromatic solvent interacts with diarylzirconocenes upon thermolysis could be answered.

Three separate solutions were thermalyzed. These solutions were di- $p$ tolylzirconocene and di-m-tolylzirconocene in benzene, and diphenylzirconocene in toluene. Upon heating at $70^{\circ} \mathrm{C}$ for ten hours followed by photochemical degradation to biphenyls, the three new diarylzirconocene structures were found to be $m$-tolylphenylzirconocene, $p$ tolylphenylzirconocene, and diphenylzirconocene.

For di-p-tolylzirconocene and di-m-tolylzirconocene, mixed tolylphenyl complexes were formed and after prolonged thermolysis, diphenylzirconocene was observed. This observation was a result of the tolyl groups being exchanged by the aromatic solvent. Alternatively, the thermolysis of diphenylzirconocene in toluene, tolyl groups from the solvent became bound to the metal and a molecule of benzene was produced as a result.

Erker concluded that upon thermolysis, the diarylzirconocenes did undergo replacement of $\sigma$-bonded ligands by aryl groups from the solvent. The fact that thermolysis of a ditolylzirconocene gave a mixture of tolylphenylzirconocenes, Erker proposed the intermediacy of an aryne complex during this exchange. It was believed that the abstraction of an ortho proton from one of the $\sigma$-bonded aryl ligands by the other aryl ligand directly led to the benzyne intermediate which then reacted with a $\mathrm{C}-\mathrm{H}$ bond of the aromatic hydrocarbon.

Their reactivity studies revealed that this benzyne species reductively coupled a variety of olefins to form zirconaindan derivatives ${ }^{14}$ (eq. 5). Erker and his co-workers coupled cis- and trans-stilbene to diphenylzirconocene to 


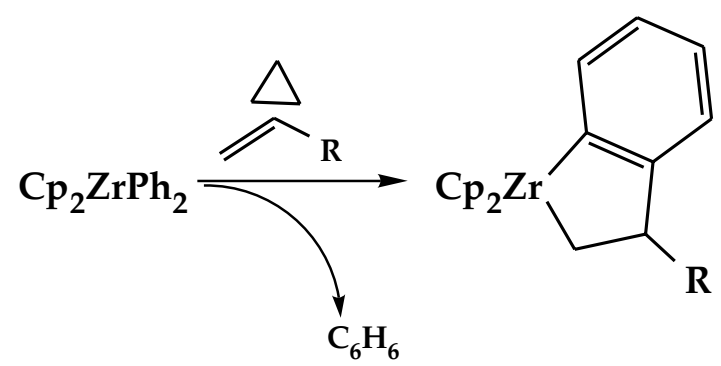

(eq. 5)

form cis- and trans-metallacycles. ${ }^{15}$ This coupling of the cis- and transisomers was shown to be stereospecific for the formation of the respective metallacyclic products. Erker expanded his reactivity studies of the thermolysis of diarylzirconocene to coupling tungsten hexacarbonyl to afford a Fischer-type metalloxycarbene complex. ${ }^{16}$ Later, Buchwald and co-workers ${ }^{17}$ extended Erker's work to couple a variety of functional groups into a cyclohexyne and thermally generated benzyne intermediate.

Previous to 1979, transition-metal complexes containing an $\eta^{2}$-benzyne group had not been isolated. Only several o-phenylene complexes containing the $\mathrm{C}_{6} \mathrm{H}_{4}$ unit bound to two or three transition metal atoms were known. ${ }^{18}$ Schrock and Churchill ${ }^{5}$ reported the first example of a benzyne ligand stabilized by complexation to a single transition-metal atom. Their development of a synthesis for tantalum-olefin complexes, Ta( $\eta 5$ $\left.\mathrm{C}_{5} \mathrm{Me}_{5}\right)\left(\mathrm{CH}_{2}=\mathrm{CHR}\right) \mathrm{Cl}_{2}$, by the decomposition of thermally unstable dialkyl complexes, $\mathrm{Ta}\left(\eta^{5}-\mathrm{C}_{5} \mathrm{Me} 5\right)\left(\mathrm{CH}_{2} \mathrm{CMe}_{3}\right)\left(\mathrm{CH}_{2} \mathrm{CH}_{2} \mathrm{R}\right) \mathrm{Cl}_{2}(\mathrm{R}=\mathrm{H}, \mathrm{Me})$ led to the preparation of stable benzyne complexes (eq. 6).

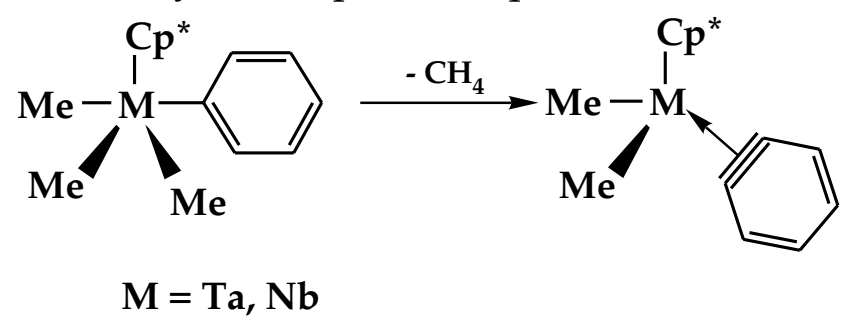

(eq. 6) 
The syntheses of these monomeric niobium- and tantalum-benzyne complexes were based on the fact that many transition metal aryl complexes decompose through a form of $\beta$-hydride elimination. ${ }^{19}$

The molecular geometry of the tantalum analogue was determined by means of single-crystal X-ray structural analysis. This structural analysis revealed that the benzyne ligand plane was oriented perpendicular to the plane of the cyclopentadienyl system. The orientation of the benzyne ligand

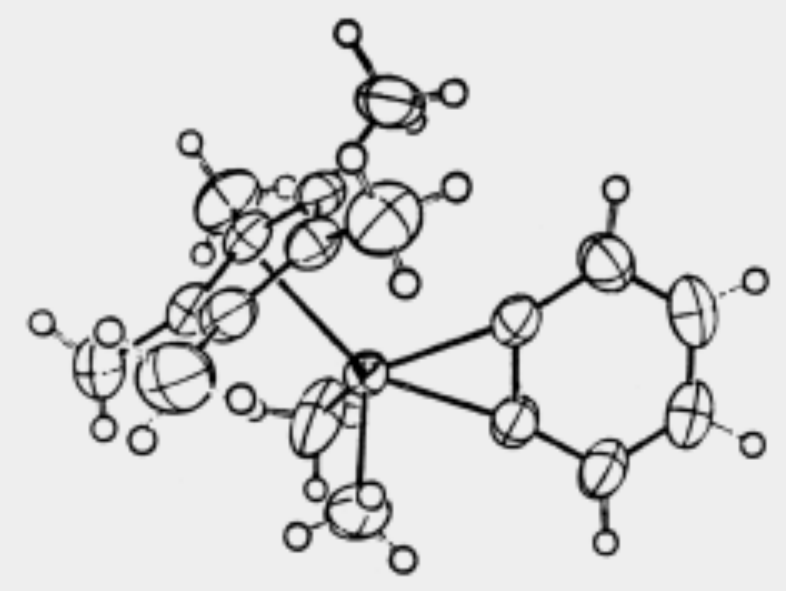

Figure 2. Molecular structure of $\mathrm{Ta}\left(\mathrm{n}^{5}-\mathrm{C}_{5} \mathrm{Me}_{5}\right)\left(\mathrm{C}_{6} \mathrm{H}_{4}\right) \mathrm{Me} 2$.

allowed maximum overlap of the benzyne's $\pi$ orbitals with both empty $\sigma$ acceptor and $\pi$-acceptor orbitals on the electron deficient metal atom. This geometric orientation resulted in stabilization of the complex.

Buchwald and co-workers subsequently prepared a zirconocenebenzyne intermediate. This was accomplished by heating a benzene solution of diphenylzirconocene in the presence of a large excess of trimethylphosphine ${ }^{20}$ shown in equation 7 . The trimethylphosphine adduct of the zirconocene-benzyne complex was isolated and its X-ray crystal structure was determined. An examination of the structural data revealed 


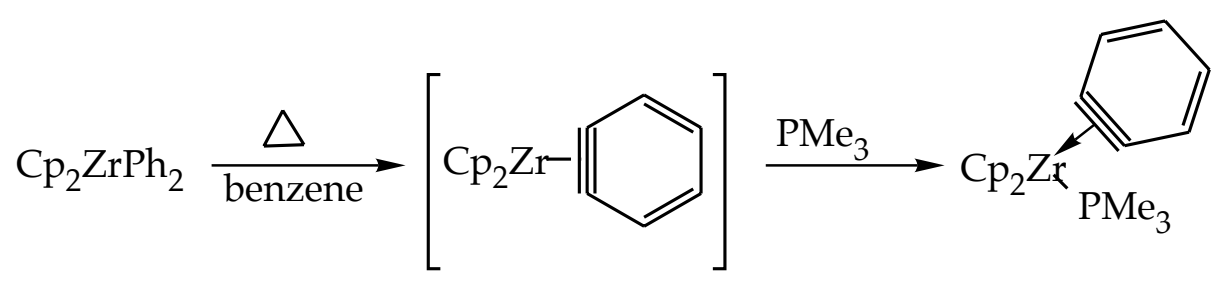

(eq. 7)

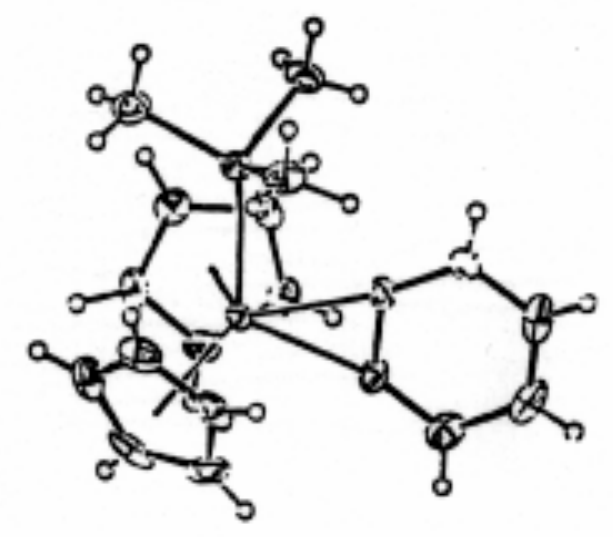

Figure 3. Molecular structure of trimethylphosphine adduct of the zirconocene-benzyne complex.

that the benzyne moiety experienced little strain, with the "triple bond" length and angles at the two carbon atoms varying only slightly from that seen in benzene. This adduct would prove useful as it would undergo clean, high yield reactions upon treatment of a number of reagents including ketones and nitriles, ${ }^{16}$ unlike that the corresponding in situ generated benzyne intermediate.

Buchwald and co-workers ${ }^{21}$ coupled the thermally-generated benzyne from diphenylzirconocene with a wide variety of nitriles to produce a series of azazirconacyclopentadienes, shown in equation 8. This coupling reaction 


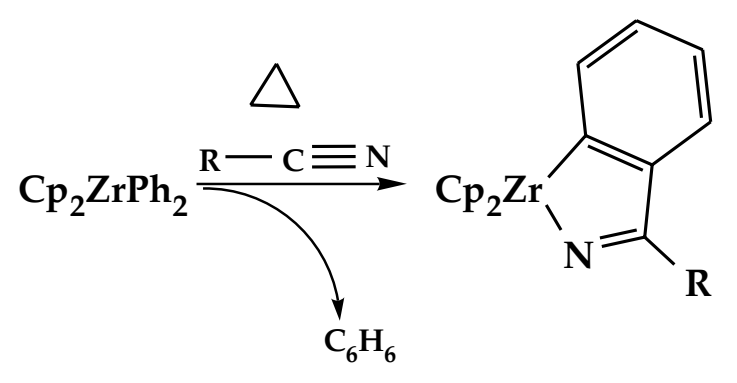

(eq. 8)

would prove useful as a means for carbon-carbon bond formation leading to conversion of the metallacyclic products obtained into a variety of organic reagents suitable for synthetic purposes.

\section{Modified Metallocene Systems}

Although the reactivity of group 4 metallocene benzynes has been extensively examined, far less is known about the influence of the electrophilicity of the metal center on the reactivity of coordinated benzyne. Recently, Bercaw and co-workers ${ }^{22}$ demonstrated that the replacement of the two cyclopentadienyl rings with the dianionic bifunctional chelating ligand $\left[\left(\mathrm{C}_{5} \mathrm{Me}_{4}\right) \mathrm{SiMe}_{2}(\mathrm{~N}-\mathrm{t}-\mathrm{Bu})\right]^{2-}$ provides an effective means for enhancing the Lewis acidity of $\mathrm{d}^{0}$ scandium complexes. The weaker $\pi$-donating character and lower steric requirement of the amido functionality enhances the metal's Lewis acidity by the simultaneous reduction of the formal electron count and the steric crowding at the metal center. The electron count is reduced by two, bringing the electron count to 14 electrons for the ansa-monocyclopentadienyl amido scandium complex, compared to 16 electrons for the corresponding scandocene complexes. Researchers at Dow Chemical Co. ${ }^{23}$ and Exxon ${ }^{24}$ later extended Bercaw's findings and attached ansa-monocyclopentadienyl ligands to group 4 metals to give complexes of the general formula, 
$\left[\left(\mathrm{C}_{5} \mathrm{R}_{4}\right) \mathrm{SiR}_{2}\left(\mathrm{NR}^{\prime \prime}\right)\right] \mathrm{MCl}_{2}$, where $\mathrm{M}=\mathrm{Ti}, \mathrm{Zr}, \mathrm{Hf} ; \mathrm{R}=$ alkyl; $\mathrm{R}^{\prime}, \mathrm{R}^{\prime \prime}=$ alkyl, aryl. They demonstrated that when these compounds are activated with methylalumoxane, the resultant species behaves as a highly active ZieglerNatta catalyst for the copolymerization of ethylene and 1-alkenes or styrene. This new ligand system offers a means of increasing the electrophilicity and decreasing the steric crowding at an electrophilic group 4 metal center.

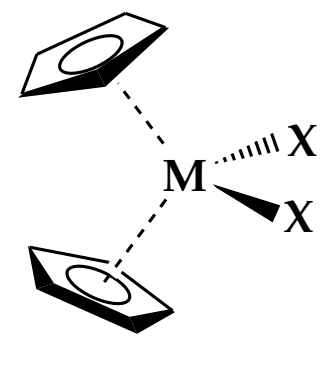

16-electron complexes

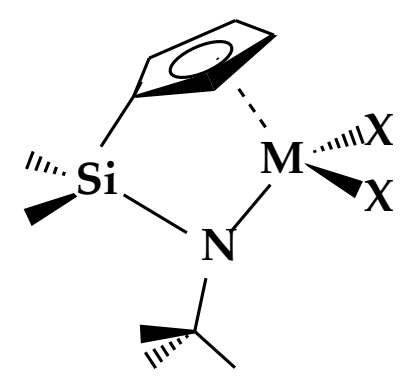

14-electron complexes

Figure 4. Structures of group 4 metallocene and ansa-monocyclopentadienyl amido metal complexes.

The molecular structures for these modified metallocene complexes indicate that the ligands similarly adopt a pseudo-tetrahedral arrangement around the metal center. With the presence of the dimethylsilyl bridge, the $\mathrm{Cp}(\mathrm{c})-\mathrm{M}-\mathrm{N}$ bite angle is $25-30^{\circ}$ smaller than the $\mathrm{Cp}(\mathrm{c})-\mathrm{M}-\mathrm{Cp}(\mathrm{c})$ angle of $125-135^{\circ}$ in the corresponding 16-electron metallocene systems. The ligand modification coupled with the availability of an additional vacant metal orbital now offers a new perspective into the reactivity associated with group 4 metallocenes. In addition, the steric and electronic features of the ligand may be varied by changing the substituents on the cyclopentadienyl and/or amido functionalities and also by using a different moiety to link the cyclopentadienyl ring to the amido group.

Two primary synthetic strategies have been developed for the synthesis of ansa-monocyclopentadienyl amido complexes: metathesis and amine 
elimination. As mentioned earlier, Bercaw's group, along with researchers at Dow Chemical Co. and Exxon, relied on the metathetical reaction of the appropriate dilithio salt or diGrignard reagent of $\left[\left(\mathrm{C}_{5} \mathrm{R}_{4}\right) \mathrm{L}\left(\mathrm{NR}^{\prime}\right)\right]^{2-}$ with a metal chloride to chelate the ansa-monocyclopentadienyl amido ligand to the electrophilic metal center (eq. 9). Okuda and co-workers ${ }^{25}$ used the same

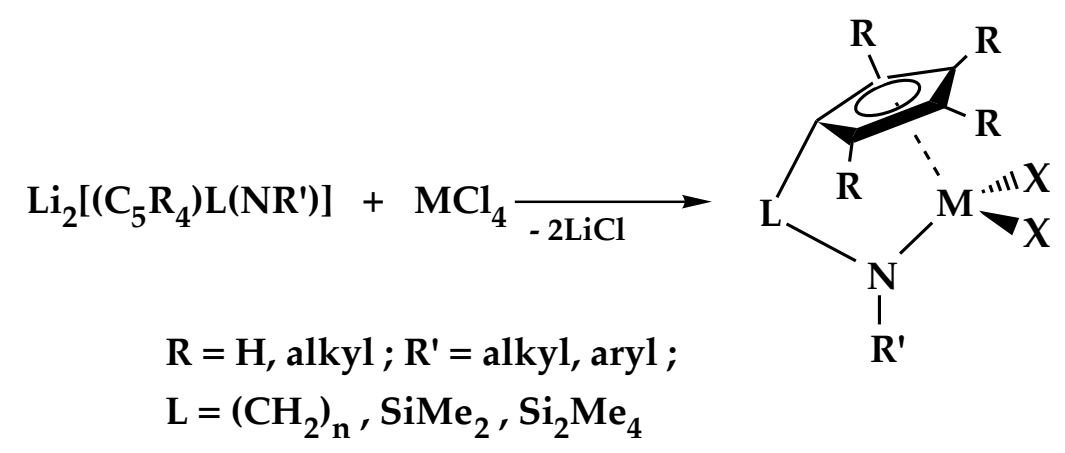

(eq. 9)

approach for the preparation of various ansa-monocyclopentadienyl $\mathrm{Ti}$ and ansa-monofluorenyl amido $\mathrm{Zr}$ compounds. Unfortunately, the metathesis route in some cases led to low isolated yields and mixtures of products.

The alternative amine elimination strategy is based on Lappert's earlier observation for the preparation of group 4 metallocenes, shown in eq. $10 .^{26}$ The reaction of $\mathrm{Zr}\left(\mathrm{NMe}_{2}\right)_{4}$ with excess cyclopentadiene produces $\left(\mathrm{C}_{5} \mathrm{H}_{5}\right)_{2} \mathrm{Zr}\left(\mathrm{NMe}_{2}\right)_{2}$ and releases two equivalents of $\mathrm{NMe}_{2} \mathrm{H}$. Teuben and coworkers $^{27}$ later adapted this strategy for the synthesis of ansamonocyclopentadienyl amido group 4 complexes that featured a three-carbon 
linkage. The reactions of $\left[\mathrm{C}_{5} \mathrm{H}_{5}\left(\mathrm{CH}_{2}\right)_{3} \mathrm{NHMe}\right]$ with $\mathrm{M}\left(\mathrm{NMe}_{2}\right)_{4}(\mathrm{M}=\mathrm{Zr}, \mathrm{Hf})$

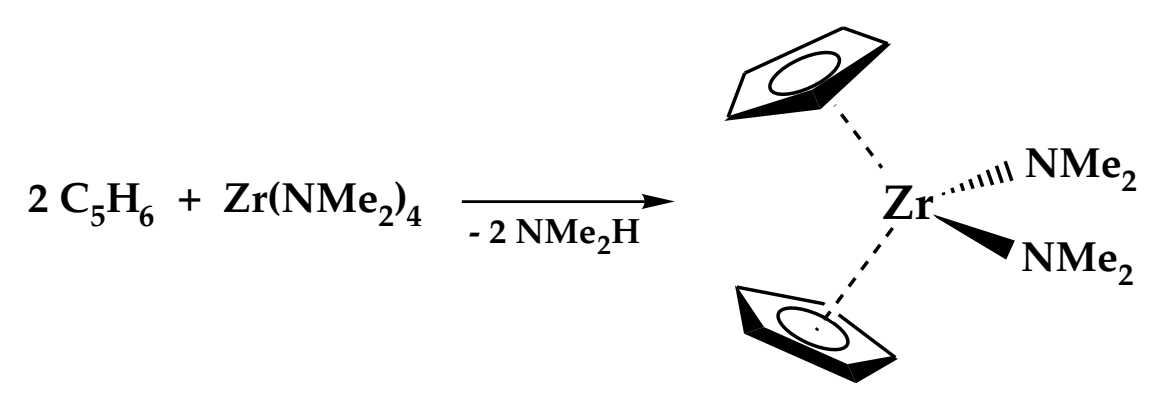

(eq. 10)

produced $\left[\left(\mathrm{C}_{5} \mathrm{H}_{4}\right) \mathrm{CH}_{2} \mathrm{CH}_{2} \mathrm{CH}_{2}\left(\mathrm{NCH}_{3}\right)\right] \mathrm{M}\left(\mathrm{NMe}_{2}\right)_{2}$ in good yields $(94 \%$ for $\mathrm{M}=\mathrm{Zr}, 58 \%$ for $\mathrm{M}=\mathrm{Hf}$ ). Because of the greater utility of halide derivatives for the preparation of other organometallic compounds, the bis(dimethylamido) derivatives were converted to their dihalide amine adduct $\left[\left(\mathrm{C}_{5} \mathrm{H}_{4}\right) \mathrm{CH}_{2} \mathrm{CH}_{2} \mathrm{CH}_{2}\left(\mathrm{NCH}_{3}\right)\right] \mathrm{MX}_{2}\left(\mathrm{NMe}_{2} \mathrm{H}\right), \quad(\mathrm{M}=\mathrm{Zr}, \quad \mathrm{Hf} ; \mathrm{X}=\mathrm{Cl}, \mathrm{I})$, by the stoichiometric addition of 2 equivalents of dimethylamine hydrohalide $(\mathrm{NMe} 2 \mathrm{H} \bullet \mathrm{HCl}$ or $\mathrm{NMe} 2 \mathrm{H} \bullet \mathrm{HI})$. Teuben and co-workers were able to synthesize a series of $\left[\left(\mathrm{C}_{5} \mathrm{H}_{4}\right) \mathrm{CH}_{2} \mathrm{CH}_{2} \mathrm{CH}_{2}\left(\mathrm{NCH}_{3}\right)\right] \mathrm{ZrR}_{2}$ complexes, where $\left(\mathrm{R}=\mathrm{CH}_{2} \mathrm{C}_{6} \mathrm{H}_{5}, \quad \mathrm{CH}_{2} \mathrm{SiMe}_{3}, \quad \mathrm{BH}_{4}\right), \quad$ and $\left\{\left[\left(\mathrm{C}_{5} \mathrm{H}_{4}\right) \mathrm{CH}_{2} \mathrm{CH}_{2} \mathrm{CH}_{2}\left(\mathrm{NCH}_{3}\right)\right] \mathrm{Zr}\left(\mathrm{CH}_{2} \mathrm{C}_{6} \mathrm{H}_{5}\right)\left(\mu-\mathrm{Cl}_{2}\right\}_{2}\right.$. The range of ansamonocyclopentadienyl amido group 4 metal complexes that can be prepared by the amine elimination route was extended by Herrmann and co-workers, ${ }^{28}$ who prepared a series of half-sandwich related compounds featuring a dimethylsilyl bridge between a cyclopentadienyl ring or indenyl group. Petersen and co-workers ${ }^{29}$ observed that the thermally-induced amine elimination reaction from 1:1 neat mixtures of $\mathrm{M}\left(\mathrm{NMe}_{2}\right)_{4}$ and $\left[\left(\mathrm{C}_{5} \mathrm{H}_{5}\right) \mathrm{SiMe}_{2}(\mathrm{~N}(\mathrm{H})-\mathrm{t}-\mathrm{Bu})\right]$ under a modest $\mathrm{N}_{2}$ purge at $110-120^{\circ} \mathrm{C}$ affords $\left[\left(\mathrm{C}_{5} \mathrm{H}_{4}\right) \mathrm{SiMe}_{2}(\mathrm{~N}-\mathrm{t}-\mathrm{Bu})\right] \mathrm{M}\left(\mathrm{NMe}_{2}\right)_{2}(\mathrm{M}=\mathrm{Ti}, \mathrm{Zr}, \mathrm{Hf})$, and $\left[\left(\mathrm{C}_{13} \mathrm{H}_{8}\right) \mathrm{SiMe}_{2}(\mathrm{~N}-\mathrm{t}-\right.$ $\mathrm{Bu})] \mathrm{Zr}(\mathrm{NMe} 2) 2 .^{2} 8$ A modified approach was subsequently used to prepare $\left[\left(\mathrm{C}_{9} \mathrm{H}_{6}\right) \mathrm{SiMe}_{2}(\mathrm{~N}-\mathrm{t}-\mathrm{Bu})\right] \mathrm{M}\left(\mathrm{NMe}_{2}\right)_{2} \quad(\mathrm{M}=\mathrm{Ti}, \quad \mathrm{Zr}, \quad \mathrm{Hf})$ and $\left[\left(\mathrm{C}_{13} \mathrm{H}_{8}\right) \mathrm{SiMe}_{2}(\mathrm{~N}-\mathrm{t}-\right.$ 
$\mathrm{Bu}) \operatorname{Zr}\left(\mathrm{NMe}_{2}\right)_{2} \cdot{ }^{30}$ The conversion of these dimethylamido complexes to the corresponding dichloride derivatives was accomplished by the addition of two equivalents of $\mathrm{SiMe}_{3} \mathrm{Cl}$, shown in eq. 11. The volatile silylamine byproduct is readily removed under reduced pressure.

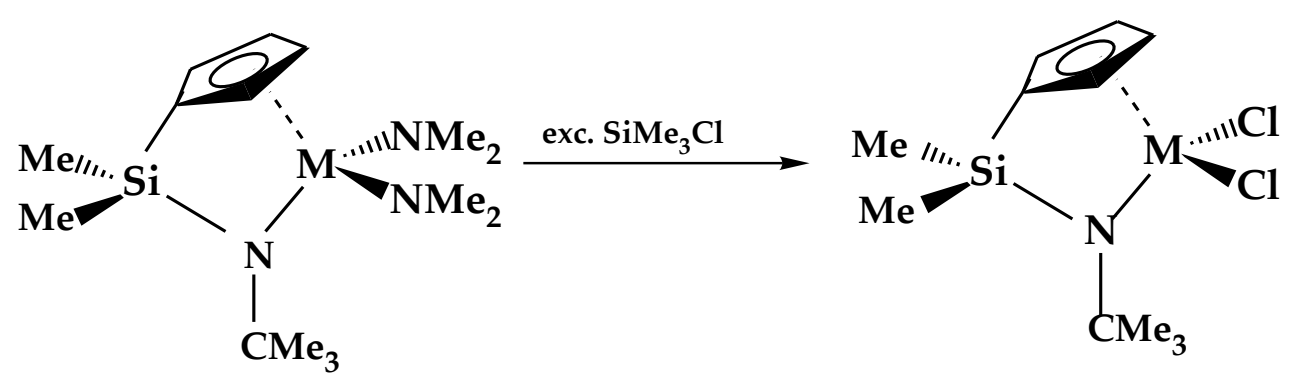

(eq. 11)

\section{Research Objectives}

Early transition metal complexes, such as $\left[\left(\mathrm{C}_{5} \mathrm{R}_{4}\right) \mathrm{SiMe}_{2}(\mathrm{~N}-\mathrm{t}-\mathrm{Bu})\right] \mathrm{ML} 2$ where $\mathrm{M}$ is a $\mathrm{d}^{0}$ group 4 metal, that contain a bifunctional monocyclopentadienyl ligand represent an emerging class of organometallic complexes with enormous chemical potential. Because of the availability of reliable, high yield syntheses of $\left[\left(\mathrm{C}_{5} \mathrm{Me}_{4}\right) \mathrm{SiMe}_{2}(\mathrm{~N}-\mathrm{t}-\mathrm{Bu})\right] \mathrm{ZrCl}_{2}$ and $\left[\left(\mathrm{C}_{5} \mathrm{H}_{4}\right) \mathrm{SiMe}_{2}(\mathrm{~N}-\mathrm{t}-\mathrm{Bu})\right] \mathrm{TiCl}_{2}$, a research effort was taken to prepare the corresponding diphenyl derivatives and investigate their reactivity toward unsaturated organic substrates upon thermolysis. The substrate chosen for the investigation of trapping the reactive benzyne intermediate was diphenylacetylene. Examination of the products obtained will provide the opportunity to evaluate the stereoelectronic consequences of this alternative ansa-metallocene ligand system on the structure and reactivity and thus differentiate their chemical reactivity from the corresponding group 4 
metallocene benzyne complexes. This new class of organometallic compounds may lead to the development of new chemical application for selective transformations in organic synthesis as well as the possible chemical potential for the generation of structures not accessible via metallocene benzyne species. 


\section{Experimental Section}

\section{Reagents}

Reagent grade hydrocarbon and etheral solvents were purified using standard methods ${ }^{31}$ and distilled under nitrogen. These solvents were then transferred to storage flasks containing either $\left[\left(\mathrm{C}_{5} \mathrm{H}_{5}\right)_{2} \mathrm{Ti}(\mu-\mathrm{Cl})_{2}\right]_{2} \quad \mathrm{Zn} \mathrm{n}^{32}$ or potassium benzophenone ketyl. Hexamethyldisiloxane was dried over $\left(\mathrm{C}_{5} \mathrm{H}_{5}\right)_{2} \mathrm{ZrMe}_{2}$. The deuterated solvents, $\mathrm{C}_{6} \mathrm{D}_{6}$ (Cambridge Isotopes, 99.5\%) and $\mathrm{CDCl}_{3}$ (Aldrich, 99.8\%) were dried over activated $4 \mathrm{~A}$ molecular sieves prior to use, as was $\mathrm{NH}_{2}-\mathrm{t}-\mathrm{Bu}$ (Acros).

Starting materials such as $\mathrm{TiCl}_{4}(\mathrm{THF})_{2}{ }^{33} \mathrm{NaCp}^{34}$ and $\mathrm{LiC}_{5} \mathrm{Me}_{4} \mathrm{H}^{35}$ were prepared by literature procedures. Other starting materials such as $\mathrm{TiCl}_{4}$ (Aldrich), $\mathrm{ZrCl}_{4}$ (Alfa), $\mathrm{LiNMe}_{2}$ (Aldrich 95\%), $\mathrm{Na}$ (Aldrich), $\mathrm{C}_{5} \mathrm{Me}_{4} \mathrm{H}_{2}$ (Boulder Scientific), dicyclopentadiene (Kodak), phenyllithium (Aldrich), phenylmagnesiumbromide (Aldrich), and phenylmagnesiumchloride (Acros) were used without further purification, whereas diphenylacetylene (Kodak) was purified by sublimation. $\mathrm{SiMe}_{2} \mathrm{Cl}_{2}$ (Acros) and $\mathrm{SiMe}_{3} \mathrm{Cl}$ (Acros) were vacuum distilled prior to use.

\section{Instrumentation}

The ${ }^{1} \mathrm{H}$ and ${ }^{13} \mathrm{C}$ NMR spectra were measured with either a JEOL GX-270 or a JEOL Eclipse 270 NMR spectrometer operating in the FT mode at 270 $\mathrm{MHz}\left({ }^{1} \mathrm{H}\right)$ or $67.5 \mathrm{MHz}\left({ }^{13} \mathrm{C}\right)$. The ${ }^{1} \mathrm{H}$ chemical shifts are referenced to the residual proton peaks of benzene- $\mathrm{d}_{6}$ at $\delta 7.15$ (vs. TMS) or chloroform- $\mathrm{d}_{1}$ at $\delta$ 7.24 (vs. TMS). The ${ }^{13} \mathrm{C}$ resonances are referenced to the central peak of benzene- $\mathrm{d}_{6}$ at $\delta 128.0$ (vs. TMS) or chloroform- $\mathrm{d}_{1}$ at $\delta 77.0$ (vs. TMS). 


\section{General Procedures}

To minimize exposure to air and moisture during the syntheses of compounds, all manipulations and reactions were carried out on a highvacuum line or in a Vacuum Atmosphere glovebox equipped with a HE-493 Dri-Train. Reactions were typically carried out in pressure equalizing filterfrits equipped with high vacuum Teflon stopcocks. All glassware were ovendried and flame-dried under vacuum prior to use. NMR sample tubes were sealed normally under 400-500 Torr of nitrogen. Nitrogen was purified by passage over reduced BTS catalysts and activated 4A molecular sieves. Elemental analyses were performed by E\&R Microanalytical Labs, Parsippany, NJ 07054.

\section{Syntheses of Compounds}

\section{Preparation of $\left(\mathrm{C}_{5} \mathrm{H}_{5}\right) \mathrm{SiMe}_{2}(\mathrm{~N}(\mathrm{H})-\mathrm{t}-\mathrm{Bu})$}

The preparation of $\left(\mathrm{C}_{5} \mathrm{H}_{5}\right) \mathrm{SiMe}_{2}(\mathrm{~N}(\mathrm{H})-\mathrm{t}-\mathrm{Bu})$ was accomplished in two separate steps, as shown in eq. 12. This compound was then used directly in an amine elimination reaction to afford the ansa-monocyclopentadienyl amido metal complex.

$$
\begin{aligned}
& \mathrm{NaC}_{5} \mathrm{H}_{5}+\text { excess } \mathrm{SiMe}_{2} \mathrm{Cl}_{2} \rightarrow\left(\mathrm{C}_{5} \mathrm{H}_{5}\right) \mathrm{SiMe}_{2} \mathrm{Cl}+\mathrm{NaCl} \quad \text { (eq. 12a) } \\
& \begin{aligned}
\left(\mathrm{C}_{5} \mathrm{H}_{5}\right) \mathrm{SiMe}_{2} \mathrm{Cl}+2 \mathrm{NH}_{2}-\mathrm{t}-\mathrm{Bu} \rightarrow\left(\mathrm{C}_{5} \mathrm{H}_{5}\right) \mathrm{SiMe}_{2}(\mathrm{~N}(\mathrm{H})-\mathrm{t}-\mathrm{Bu}) & \\
& +\mathrm{NH}_{2}-\mathrm{t}-\mathrm{Bu} \bullet \mathrm{HCl} \quad \text { (eq. 12b) }
\end{aligned}
\end{aligned}
$$




\section{(a) Preparation of chlorocyclopentadienyldimethylsilane, $\left(\mathrm{C}_{5} \mathrm{H}_{5}\right) \mathrm{SiMe}_{2} \mathrm{Cl}$}

A $6.00 \mathrm{~g}$ sample $(68.1 \mathrm{mmol})$ of $\mathrm{NaC}_{5} \mathrm{H}_{5}$ was added to an addition sidearm, which was then attached to a $250 \mathrm{~mL}$ three-neck flask. After connecting the reaction flask to a filter frit assembly, the third neck was capped and the assembly was evacuated. Diethyl ether (ca. $150 \mathrm{~mL}$ ) and 33.0 $\mathrm{mL}(272.5 \mathrm{mmol})$ of $\mathrm{SiMe}_{2} \mathrm{Cl}_{2}$ were introduced by vacuum distillation. The reaction mixture was cooled in a liquid $\mathrm{N}_{2} / 2$-propanol bath and stirred while the $\mathrm{NaC}_{5} \mathrm{H}_{5}$ was added incremently over a two hour period. Upon completion of the addition, the reaction mixture was allowed to warm to room temperature and stirred overnight. The mixture was filtered and the solvent and excess $\mathrm{SiMe}_{2} \mathrm{Cl}_{2}$ were removed by vacuum distillation while the flask containing the mixture was kept at $0^{\circ} \mathrm{C}$, leaving $6.85 \mathrm{~g}(63.3 \%$ yield $)$ of product as a light yellow oil.

\section{(b) Preparation of tert-butylaminocyclopentadienyldimethylsilane, $\left(\mathrm{C}_{5} \mathrm{H}_{5}\right) \mathrm{SiMe}_{2}(\mathrm{~N}(\mathrm{H})-\mathrm{t}-\mathrm{Bu})$}

All of the $\left(\mathrm{C}_{5} \mathrm{H}_{5}\right) \mathrm{SiMe}_{2} \mathrm{Cl}(6.85 \mathrm{~g}, 43.19 \mathrm{mmol})$ isolated from the preceding reaction was added to a $200 \mathrm{~mL}$ round bottom flask which was then attached to a filter frit assembly. THF (ca. $100 \mathrm{~mL}$ ) and $9.06 \mathrm{~mL} \mathrm{NH}_{2}$-t-Bu (86.3 mmol) were added to the reaction flask via vacuum distillation. A white precipitate of $\mathrm{NH}_{2}-\mathrm{t}-\mathrm{Bu} \bullet \mathrm{HCl}$ formed while the reaction was stirred for three days. The solution was filtered and the solvent was removed under reduced pressure to give $6.07 \mathrm{~g}\left(71.9 \%\right.$ yield) of product as a yellow oil. The ${ }^{1} \mathrm{H}$ NMR spectrum contains three separate sets of resonance for the methyl groups of the t-butyl and the dimethylsilyl linkage consistent with the presence of three cyclopentadiene isomers. ${ }^{27}$ 


\section{Preparation of $\left(\mathrm{C}_{5} \mathrm{Me}_{4} \mathrm{H}\right) \mathrm{SiMe}_{2}(\mathrm{~N}(\mathrm{H})-\mathrm{t}-\mathrm{Bu})$}

The preparation of $\left(\mathrm{C}_{5} \mathrm{Me}_{4} \mathrm{H}\right) \mathrm{SiMe}_{2}(\mathrm{~N}(\mathrm{H})$-t-Bu) was also accomplished in two separate steps, as shown in eq. 13. This compound was then used directly in an amine elimination reaction to afford the ansamonotetramethylcyclopentadienyl amido metal complex.

$$
\begin{aligned}
& \mathrm{Li}\left(\mathrm{C}_{5} \mathrm{Me}_{4} \mathrm{H}\right)+\text { excess } \mathrm{SiMe}_{2} \mathrm{Cl}_{2} \rightarrow\left(\mathrm{C}_{5} \mathrm{Me}_{4} \mathrm{H}\right) \mathrm{SiMe}_{2} \mathrm{Cl} \\
& \begin{aligned}
\left(\mathrm{C}_{5} \mathrm{Me}_{4} \mathrm{H}\right) \mathrm{SiMe}_{2} \mathrm{Cl}+2 \mathrm{NH}_{2}-\mathrm{t}-\mathrm{Bu} \rightarrow & \left(\mathrm{C}_{5} \mathrm{Me}_{4} \mathrm{H}\right) \mathrm{SiMe}_{2}(\mathrm{~N}(\mathrm{H})-\mathrm{t}-\mathrm{Bu}) \\
& +\mathrm{NH}_{2}-\mathrm{t}-\mathrm{Bu} \bullet \mathrm{HCl} \quad \text { (eq. 13b) }
\end{aligned}
\end{aligned}
$$

\section{(a) Preparation of chloromethylcyclopentadienyldimethylsilane, $\left(\mathrm{C}_{5} \mathrm{Me}_{4} \mathrm{H}\right) \mathrm{SiMe}_{2} \mathrm{Cl}$}

A $2.44 \mathrm{~g}$ sample $(19.0 \mathrm{mmol})$ of $\mathrm{LiC}_{5} \mathrm{Me}_{4} \mathrm{H}$ was placed in a $200 \mathrm{~mL}$ Solvseal flask. Approximately $40 \mathrm{~mL}$ of THF and $7.7 \mathrm{~mL}(63.4 \mathrm{mmol})$ of $\mathrm{SiMe}_{2} \mathrm{Cl}_{2}$ were added by vacuum distillation. The reaction mixture was then allowed to warm to room temperature and stirred overnight. The solvent and excess $\mathrm{SiMe}_{2} \mathrm{Cl}_{2}$ were removed under vacuum and were replaced by an equal amount of pentane. After filtration, the pentane was removed, leaving $3.75 \mathrm{~g}$ (91.5\% yield) of $\left(\mathrm{C}_{5} \mathrm{Me}_{4} \mathrm{H}\right) \mathrm{SiMe}_{2} \mathrm{Cl}$ as a light yellow oil.

(b) Preparation of tert-butylaminotetramethylcyclopentadienyldimethylsilane,

\section{$\left(\mathrm{C}_{5} \mathrm{Me}_{4} \mathrm{H}\right) \mathrm{SiMe}_{2}(\mathrm{~N}(\mathrm{H})-\mathrm{t}-\mathrm{Bu})$}

The $\left(\mathrm{C}_{5} \mathrm{Me}_{4} \mathrm{H}\right) \mathrm{SiMe}_{2} \mathrm{Cl}(3.75 \mathrm{~g}, 17.4 \mathrm{mmol})$ was transferred to another frit assembly. THF (ca. $50 \mathrm{~mL}$ ) and $4.6 \mathrm{~mL}(43.8 \mathrm{mmol})$ of $\mathrm{NH}_{2}-\mathrm{t}-\mathrm{Bu}$ were then added. The mixture was allowed to warm to room temperature and stirred 
for three days. After removal of solvent, the product was extracted with pentane (ca. $30 \mathrm{~mL}$ ) yielding $3.52 \mathrm{~g}(80.2 \%)$ of $\left(\mathrm{C}_{5} \mathrm{Me}_{4} \mathrm{H}\right) \mathrm{SiMe}_{2}(\mathrm{~N}(\mathrm{H})-\mathrm{t}-\mathrm{Bu})$ as a light yellow oil.

Synthesis of $\mathrm{M}\left(\mathrm{NMe}_{2}\right)_{4}, \mathrm{M}=\mathrm{Ti}, \mathrm{Zr}$.

\section{(a) Preparation of $\mathrm{Ti}\left(\mathrm{NMe}_{2}\right)_{4}$}

A $5.13 \mathrm{~g}$ sample $(15.3 \mathrm{mmol})$ of $\mathrm{TiCl}_{4}(\mathrm{THF})_{2}$ was placed in an addition sidearm and connected to a two-neck flask containing $3.14 \mathrm{~g}(61.6 \mathrm{mmol})$ of $\mathrm{LiNMe}_{2}$. Toluene (ca. $50 \mathrm{~mL}$ ) was added via vacuum transfer and the flask was then cooled in a liquid $\mathrm{N}_{2} / 2$-propanol bath. The $\mathrm{TiCl}_{4}(\mathrm{THF})_{2}$ was slowly added to the stirring reaction mixture. The mixture was stirred overnight at room temperature. The solution was then filtered and the toluene was removed under reduced pressure. Removal of toluene left $3.03 \mathrm{~g}(87.8 \%$ yield) of $\mathrm{Ti}\left(\mathrm{NMe}_{2}\right)_{4}$ as a yellow oil.

\section{(b) Preparation of $\mathrm{Zr}\left(\mathrm{NMe}_{2}\right)_{4}$}

A $6.00 \mathrm{~g}$ sample $(25.7 \mathrm{mmol})$ of $\mathrm{ZrCl}_{4}$ was placed in an addition sidearm and connected to a two-neck flask containing $5.66 \mathrm{~g}(110.9 \mathrm{mmol})$ of $\mathrm{LiNMe}_{2}$. Toluene (ca. $125 \mathrm{~mL}$ ) was added via vacuum transfer and the $\mathrm{ZrCl}_{4}$ was added to the reaction mixture over a one hour period. The reaction was stirred overnight. The solution was then filtered and the toluene was removed under reduced pressure. The product was purified by sublimation at $40^{\circ} \mathrm{C}$ and $10^{-4}$ Torr affording $4.49 \mathrm{~g}(65.2 \%$ yield $)$ of $\mathrm{Zr}\left(\mathrm{NMe}_{2}\right)_{4}$ as a light yellow semicrystalline solid. 


\section{Synthesis of $\left[\left(\mathrm{C}_{5} \mathrm{R}_{4}\right) \mathrm{SiMe}_{2}(\mathrm{~N}-\mathrm{t}-\mathrm{Bu})\right] \mathrm{M}\left(\mathrm{NMe}_{2}\right)_{2}, \mathrm{R}=\mathrm{H}, \mathrm{Me} ; \mathrm{M}=\mathrm{Ti}, \mathrm{Zr}$}

\section{via Amine Elimination}

\section{(a) Preparation of $\left[\left(\mathrm{C}_{5} \mathrm{H}_{4}\right) \mathrm{SiMe}_{2}(\mathrm{~N}-\mathrm{t}-\mathrm{Bu})\right] \mathrm{Ti}\left(\mathrm{NMe}_{2}\right)_{2}$}

A $1.96 \mathrm{~g}$ sample $(8.74 \mathrm{mmol})$ of $\mathrm{Ti}\left(\mathrm{NMe}_{2}\right)_{4}$ was combined with $1.71 \mathrm{~g}$ $(8.75 \mathrm{mmol})$ of $\left(\mathrm{C}_{5} \mathrm{H}_{5}\right) \mathrm{SiMe}_{2}(\mathrm{~N}(\mathrm{H})-\mathrm{t}-\mathrm{Bu})$ in a $100 \mathrm{~mL}$ pear-shaped flask equipped with a vacuum adapter. The neat reaction mixture was heated to $120^{\circ} \mathrm{C}$ and stirred overnight under a modest $\mathrm{N}_{2}$ purge. During the course of the reaction, an orange solid, $\left[\left(\mathrm{C}_{5} \mathrm{H}_{4}\right) \mathrm{SiMe}_{2}(\mathrm{~N}-\mathrm{t}-\mathrm{Bu})\right] \mathrm{Ti}\left(\mathrm{NMe}_{2}\right)_{2}$, collected on the walls of the reaction flask. Following the evacuation of volatiles, sublimation of the product at $40^{\circ} \mathrm{C}$ and $10^{-4}$ Torr gave $2.21 \mathrm{~g}(76.7 \%$ yield $)$ of $\left[\left(\mathrm{C}_{5} \mathrm{H}_{4}\right) \mathrm{SiMe}_{2}(\mathrm{~N}-\mathrm{t}-\mathrm{Bu})\right] \mathrm{Ti}\left(\mathrm{NMe}_{2}\right)_{2}$ as a semicrystalline solid. ${ }^{1} \mathrm{H} \mathrm{NMR}\left(\mathrm{C}_{6} \mathrm{D}_{6}\right.$, ${ }^{3} \mathrm{~J}_{\mathrm{HH}}$ in $\left.\mathrm{Hz}\right): \delta 6.25,5.99\left(\mathrm{C}_{5} \mathrm{H}_{4}, \mathrm{t}, 2.3\right), 2.95\left(\mathrm{NMe}_{2}, \mathrm{~s}\right), 1.31\left(\mathrm{NCMe}_{3}, \mathrm{~s}\right), 0.51$ $\left(\mathrm{SiMe}_{2}, \mathrm{~s}\right)$. Gated nondecoupled ${ }^{13} \mathrm{C} \mathrm{NMR}\left(\mathrm{C}_{6} \mathrm{D}_{6},{ }^{1} \mathrm{~J}_{\mathrm{CH}}\right.$ in $\left.\mathrm{Hz}\right): \delta 117.9,116.3$ (proximal and distal carbons of $\mathrm{C}_{5} \mathrm{H}_{4}, \mathrm{~d}, 169$ ), 107 (bridgehead C, s), 59.6 $\left(\mathrm{NCMe}_{3}, \mathrm{~s}\right), 49.6\left(\mathrm{NMe}_{2}, \mathrm{q}, 133\right), 34.0\left(\mathrm{NCMe}_{3}, \mathrm{q}, 124\right), 1.7\left(\mathrm{SiMe}_{2}, \mathrm{q}, 119\right)$.

\section{(b) Preparation of $\left[\left(\mathrm{C}_{5} \mathrm{H}_{4}\right) \mathrm{SiMe}_{2}(\mathrm{~N}-\mathrm{t}-\mathrm{Bu})\right] \mathrm{Zr}\left(\mathrm{NMe}_{2}\right)_{2}$}

A $3.00 \mathrm{~g}$ sample $(11.2 \mathrm{mmol})$ of $\mathrm{Zr}\left(\mathrm{NMe}_{2}\right)_{2}$ was combined with $2.19 \mathrm{~g}$ (11.2 mmol) of $\left(\mathrm{C}_{5} \mathrm{H}_{5}\right) \mathrm{SiMe}_{2}(\mathrm{~N}(\mathrm{H})-\mathrm{t}-\mathrm{Bu})$ in a $100 \mathrm{~mL}$ pear-shaped flask equipped with a high vacuum adapter. The neat reaction mixture was heated to $120^{\circ} \mathrm{C}$ and stirred for two days. The volatile $\mathrm{NMe}_{2} \mathrm{H}$ was removed by a slow purge of $\mathrm{N}_{2}$ and periodic evacuation of the reaction mixture. As the reaction proceeded, a light yellow solid formed on the walls of the flask. Following evacuation of volatiles, the product was collected via sublimation at $40^{\circ} \mathrm{C}$ and $10^{-4}$ Torr, giving $2.56 \mathrm{~g}(61.2 \%$ yield $)$ of $\left[\left(\mathrm{C}_{5} \mathrm{H}_{4}\right) \mathrm{SiMe}_{2}(\mathrm{~N}-\mathrm{t}-\right.$ $\mathrm{Bu})] \mathrm{Zr}\left(\mathrm{NMe}_{2}\right)_{2}$ as a light yellow waxy solid. ${ }^{1} \mathrm{H} \mathrm{NMR}\left(\mathrm{C}_{6} \mathrm{D}_{6},{ }^{3} \mathrm{~J}_{\mathrm{HH}}\right.$ in $\left.\mathrm{Hz}\right)$ : 
$\delta$ 6.31, $6.18\left(\mathrm{C}_{5} \mathrm{H}_{4}, \mathrm{t}, 2.4\right), 2.80\left(\mathrm{NMe}_{2}, \mathrm{~s}\right), 1.28\left(\mathrm{NCMe}_{3}, \mathrm{~s}\right), 0.55\left(\mathrm{SiMe}_{2}, \mathrm{~s}\right)$. Gated nondecoupled ${ }^{13} \mathrm{C}$ NMR $\left(\mathrm{C}_{6} \mathrm{D}_{6},{ }^{1} \mathrm{~J}_{\mathrm{CH}}\right.$ in $\left.\mathrm{Hz}\right): \delta 118.4,114.8$ (proximal and distal carbons of $\left.\mathrm{C}_{5} \mathrm{H}_{4}, \mathrm{~d}, 169\right), 108.3$ (bridgehead carbon, s), 55.9 ( $\left.\mathrm{NCMe}_{3}, \mathrm{~s}\right), 44.0$ $\left(\mathrm{NMe}_{2}, \mathrm{q}, 132\right), 34.5\left(\mathrm{NCMe}_{3}, \mathrm{q}, 124\right), 2.34\left(\mathrm{SiMe}_{2}, \mathrm{q}, 117\right)$.

\section{(c) Preparation of $\left[\left(\mathrm{C}_{5} \mathrm{Me}_{4}\right) \mathrm{SiMe}_{2}(\mathrm{~N}-\mathrm{t}-\mathrm{Bu})\right] \mathrm{Zr}\left(\mathrm{NMe}_{2}\right)_{2}$}

A $2.41 \mathrm{~g}$ sample $(9.00 \mathrm{mmol})$ of $\mathrm{Zr}\left(\mathrm{NMe}_{2}\right)_{4}$ was combined with $2.26 \mathrm{~g}$ $(8.98 \mathrm{mmol})$ of $\left(\mathrm{C}_{5} \mathrm{Me}_{4} \mathrm{H}\right) \mathrm{SiMe}_{2}(\mathrm{~N}(\mathrm{H})-\mathrm{t}-\mathrm{Bu})$ and toluene $($ ca. $3 \mathrm{~mL})$ in a $100 \mathrm{~mL}$ pear-shaped flask equipped with a vacuum adapter. The reaction mixture was heated to $110^{\circ} \mathrm{C}$ and stirred 24 hours under a modest $\mathrm{N}_{2}$ purge. As the reaction proceeded, solid formed on the walls of the reaction flask. The toluene was removed under reduced pressure and the product was purified by sublimation at $60^{\circ} \mathrm{C}$ and $10^{-4}$ Torr to give $3.60 \mathrm{~g}(93.5 \%$ yield) of $\left[\left(\mathrm{C}_{5} \mathrm{Me}_{4}\right) \mathrm{SiMe}_{2}(\mathrm{~N}-\mathrm{t}-\mathrm{Bu})\right] \mathrm{Zr}\left(\mathrm{NMe}_{2}\right)_{2}$ as an off-white solid. ${ }^{1} \mathrm{H} \mathrm{NMR}\left(\mathrm{C}_{6} \mathrm{D}_{6}\right): \delta 2.84$ $\left(\mathrm{NMe}_{2}, \mathrm{~s}\right), 2.14,1.90\left(\mathrm{C}_{5} \mathrm{Me}_{4}, \mathrm{~s}\right), 1.33\left(\mathrm{NCMe}_{3}\right), 0.65\left(\mathrm{SiMe}_{2}, \mathrm{~s}\right) . \quad$ Gated nondecoupled ${ }^{13} \mathrm{C}$ NMR $\left(\mathrm{C}_{6} \mathrm{D}_{6},{ }^{1} \mathrm{~J}_{\mathrm{CH}}\right.$ in $\mathrm{Hz}$ ): $\delta 127.4,124.6$ (proximal and distal carbons of $\left.\mathrm{C}_{5} \mathrm{Me}_{4}, \mathrm{~s}\right), 100.9$ (bridgehead C, s), $56.0\left(\mathrm{NCMe}_{3}, \mathrm{~s}\right), 44.5\left(\mathrm{NMe}_{2}, \mathrm{q}\right.$, 136), 34.6 ( $\left.\mathrm{NCMe}_{3}, \mathrm{q}, 125\right), 14.0,11.1\left(\mathrm{C}_{5} \mathbf{M e}_{4}, \mathrm{q}, 128\right), 7.44\left(\mathrm{SiMe}_{2}, \mathrm{q}, 120\right)$.

Conversion of $\left[\left(\mathrm{C}_{5} \mathrm{R}_{4}\right) \mathrm{SiMe}_{2}(\mathrm{~N}-\mathrm{t}-\mathrm{Bu})\right] \mathrm{M}\left(\mathrm{NMe}_{2}\right)_{2},(\mathrm{R}=\mathrm{H}, \mathrm{Me} ; \mathrm{M}=\mathrm{Ti}, \mathrm{Zr})$, to $\left[\left(\mathrm{C}_{5} \mathrm{R}_{4}\right) \mathrm{SiMe}_{2}(\mathrm{~N}-\mathrm{t}-\mathrm{Bu})\right] \mathrm{MCl}_{2}$.

\section{(a) Synthesis of $\left[\left(\mathrm{C}_{5} \mathrm{H}_{4}\right) \mathrm{SiMe}_{2}(\mathrm{~N}-\mathrm{t}-\mathrm{Bu})\right] \mathrm{TiCl}_{2}$}

A $2.48 \mathrm{~g}$ sample $(7.52 \mathrm{mmol})$ of $\left[\left(\mathrm{C}_{5} \mathrm{H}_{4}\right) \mathrm{SiMe}_{2}(\mathrm{~N}-\mathrm{t}-\mathrm{Bu})\right] \mathrm{Ti}\left(\mathrm{NMe}_{2}\right)_{2}$ was dissolved in ca. $5 \mathrm{~mL}$ toluene. $\mathrm{SiMe}_{3} \mathrm{Cl}(2.1 \mathrm{~mL}, 16.5 \mathrm{mmol})$ was added by vacuum transfer, and the reaction mixture was stirred $24 \mathrm{~h}$ at $65^{\circ} \mathrm{C}$. As the reaction proceeded, the original reddish brown color of the solution became 
dark and then turned orange once the reaction was complete. After removal of the volatiles, the procedure was repeated one more time to ensure complete conversion. A sublimator was then attached and $2.22 \mathrm{~g}$ (94.4\% yield) of $\left[\left(\mathrm{C}_{5} \mathrm{H}_{4}\right) \mathrm{SiMe}_{2}(\mathrm{~N}-\mathrm{t}-\mathrm{Bu})\right] \mathrm{TiCl}_{2}$ as an orange solid was collected by sublimation at $50-60^{\circ} \mathrm{C}$ and $10^{-4}$ Torr. ${ }^{1} \mathrm{H}$ NMR $\left(\mathrm{C}_{6} \mathrm{D}_{6},{ }^{3} \mathrm{~J}_{\mathrm{HH}}\right.$ in $\left.\mathrm{Hz}\right): \delta 6.60,6.07\left(\mathrm{C}_{5} \mathrm{H}_{4}, \mathrm{t}, 2.3\right)$, $1.38\left(\mathrm{NCMe}_{3}, \mathrm{~s}\right), 0.18\left(\mathrm{SiMe}_{2}, \mathrm{~s}\right) ;{ }^{13} \mathrm{C}\left\{{ }^{1} \mathrm{H}\right\} \mathrm{NMR}\left(\mathrm{C}_{6} \mathrm{D}_{6}\right): \delta 126.3,125.6$ (proximal and distal carbons of $\left.\mathrm{C}_{5} \mathrm{H}_{4}\right), 110.0$ (bridgehead C), $63.7\left(\mathrm{NCMe}_{3}\right), 32.2\left(\mathrm{NCMe}_{3}\right)$, $0.20\left(\mathrm{SiMe}_{2}\right)$.

\section{(b) Synthesis of $\left\{\left[\left(\mathrm{C}_{5} \mathrm{H}_{4}\right) \mathrm{SiMe}_{2}(\mathrm{~N}-\mathrm{t}-\mathrm{Bu})\right] \mathrm{ZrCl}(\mu-\mathrm{Cl})\right\}_{2}$}

A $2.52 \mathrm{~g}$ sample $(6.76 \mathrm{mmol})$ was placed in a $100 \mathrm{~mL}$ pear-shaped flask. Toluene (ca. $25 \mathrm{~mL})$ and $1.72 \mathrm{~mL}(13.5 \mathrm{mmol})$ of $\mathrm{SiMe}_{3} \mathrm{Cl}$ were added via vacuum distillation. The reaction mixture was stirred $24 \mathrm{~h}$ at $65^{\circ} \mathrm{C}$. The solvent was removed under reduced pressure. The remaining solid was washed with pentane $(c a .20 \mathrm{~mL})$ to remove soluble impurities. The product was dried under reduced pressure leaving $2.18 \mathrm{~g}(90.9 \%$ yield $)$ of $\left\{\left[\left(\mathrm{C}_{5} \mathrm{H}_{4}\right) \mathrm{SiMe}_{2}(\mathrm{~N}-\mathrm{t}-\mathrm{Bu})\right] \mathrm{ZrCl}(\mu-\mathrm{Cl})\right\}_{2}$ as a dry, off-white solid. ${ }^{1} \mathrm{H} \mathrm{NMR}\left(\mathrm{CDCl}_{3}\right.$, ${ }^{3} \mathrm{~J}_{\mathrm{HH}}$ in $\left.\mathrm{Hz}\right): \delta 6.91,6.44\left(\mathrm{C}_{5} \mathrm{H}_{4}, \mathrm{t}, 2.3\right), 1.38\left(\mathrm{NCMe}_{3}, \mathrm{~s}\right), 0.54\left(\mathrm{SiMe}_{2}, \mathrm{~s}\right)$. Gated nondecoupled ${ }^{13} \mathrm{C} \mathrm{NMR}\left(\mathrm{CDCl}_{3},{ }^{1} \mathrm{~J}_{\mathrm{CH}}\right.$ in $\left.\mathrm{Hz}\right): \delta 122.1,121.2$ (proximal and distal carbons of $\left.\mathrm{C}_{5} \mathrm{H}_{4}, \mathrm{~d}, 174\right), 109.8$ (bridgehead carbon, s), $57.7\left(\mathrm{NCMe}_{3}, \mathrm{~s}\right)$, $32.6\left(\mathrm{NCMe}_{3}, \mathrm{q}, 125\right), 0.90\left(\mathrm{SiMe}_{2}, \mathrm{q}, 120\right)$.

\section{(c) Synthesis of $\left[\left(\mathrm{C}_{5} \mathrm{Me}_{4}\right) \mathrm{SiMe}_{2}(\mathrm{~N}-\mathrm{t}-\mathrm{Bu})\right] \mathrm{ZrCl}_{2}$}

A $6.98 \mathrm{~g}$ sample $(16.2 \mathrm{mmol})$ of $\left[\left(\mathrm{C}_{5} \mathrm{Me}_{4}\right) \mathrm{SiMe}_{2}(\mathrm{~N}-\mathrm{t}-\mathrm{Bu})\right] \mathrm{Zr}\left(\mathrm{NMe}_{2}\right)_{2}$ was placed in a $100 \mathrm{~mL}$ round bottom flask. Approximately $25 \mathrm{~mL}$ of toluene and $5 \mathrm{~mL}(39.3 \mathrm{mmol})$ of $\mathrm{SiMe}_{3} \mathrm{Cl}$ were added by vacuum distillation. The reaction mixture was stirred $24 \mathrm{~h}$ at $60^{\circ} \mathrm{C}$. The solvent was then removed 
from the resulting yellow reaction mixture. After removal of solvent, the remaining solid was washed with approximately $20 \mathrm{~mL}$ pentane, leaving $6.15 \mathrm{~g}(92 \%$ yield $)$ of $\left[\left(\mathrm{C}_{5} \mathrm{Me}_{4}\right) \mathrm{SiMe}_{2}(\mathrm{~N}-\mathrm{t}-\mathrm{Bu})\right] \mathrm{ZrCl}_{2}$ as a dry off-white solid. ${ }^{1} \mathrm{H}$ NMR $\left(\mathrm{CDCl}_{3}\right): \delta 2.18,2.12\left(\mathrm{C}_{5} \mathrm{Me}_{4}, \mathrm{~s}\right), 1.39\left(\mathrm{NCMe}_{3}, \mathrm{~s}\right), 0.61\left(\mathrm{SiMe}_{2}, \mathrm{~s}\right)$. Gated nondecoupled ${ }^{13} \mathrm{C}$ NMR $\left(\mathrm{CDCl}_{3},{ }^{1} \mathrm{~J}_{\mathrm{CH}}\right.$ in $\left.\mathrm{Hz}\right): \delta 134.2,131.5$ (proximal and distal carbons of $\left.\mathrm{C}_{5} \mathrm{Me}_{4}, \mathrm{~s}\right), 101.0$ (bridgehead carbon, s), $56.7\left(\mathrm{NCMe}_{3}, \mathrm{~s}\right), 33.0\left(\mathrm{NCMe}_{3}\right.$, q, 125), 14.7, $12.0\left(\mathrm{C}_{5} \mathbf{M e}_{4}, \mathrm{q}, 128\right), 6.01\left(\mathrm{SiMe}_{2}, \mathrm{q}, 120\right)$.

\section{Preparation of Diphenyl Derivatives}

\section{(a) Synthesis of $\left[\left(\mathrm{C}_{5} \mathrm{H}_{4}\right) \mathrm{SiMe}_{2}(\mathrm{~N}-\mathrm{t}-\mathrm{Bu})\right] \mathrm{Ti}\left(\mathrm{C}_{6} \mathrm{H}_{5}\right)_{2}$}

A $1.50 \mathrm{~g}$ sample $(4.8 \mathrm{mmol})$ of $\left[\left(\mathrm{C}_{5} \mathrm{H}_{4}\right) \mathrm{SiMe}_{2}(\mathrm{~N}-\mathrm{t}-\mathrm{Bu})\right] \mathrm{TiCl}_{2}$ was placed in a two neck round bottom flask with one neck capped with a suba-seal septum extension and the second neck attached to a filter frit assembly. Diethyl ether (ca.. $30 \mathrm{~mL}$ ) was added by vacuum distillation. The reaction mixture was then cooled in a liquid $\mathrm{N}_{2} / 2$-propanol bath. While stirring under a $\mathrm{N}_{2}$ flush, 3.20 $\mathrm{mL}\left(3.0 \mathrm{M}\right.$ in $\left.\mathrm{Et}_{2} \mathrm{O}\right) \mathrm{PhMgBr}$ was added dropwise via syringe over a 45 minute period. The solution was then allowed to warm to room temperature and stirred overnight. During the course of the reaction, the original orange color of the solution became deep red. The solvent was removed under reduced pressure and product was extracted from the remaining residue with an equal amount of pentane and filtered. Removal of the pentane left $1.08 \mathrm{~g}(56.6 \%$ yield $)$ of $\left[\left(\mathrm{C}_{5} \mathrm{H}_{4}\right) \mathrm{SiMe}_{2}(\mathrm{~N}-\mathrm{t}-\mathrm{Bu})\right] \mathrm{Ti}\left(\mathrm{C}_{6} \mathrm{H}_{5}\right)_{2}$ as a dark red solid. ${ }^{1} \mathrm{H} \mathrm{NMR}\left(\mathrm{C}_{6} \mathrm{D}_{6}\right.$, ${ }^{3} \mathrm{~J}_{\mathrm{HH}}$ in $\left.\mathrm{Hz}\right): \delta 8.14,7.20,7.09\left(\mathrm{C}_{6} \mathrm{H}_{5}, \mathrm{~m}\right), 6.56,5.27\left(\mathrm{C}_{5} \mathrm{H}_{4}, \mathrm{t}, 2.1\right), 0.90\left(\mathrm{NCMe}_{3}, \mathrm{~s}\right)$, $0.61\left(\mathrm{SiMe}_{2}, \mathrm{~s}\right)$. Gated nondecoupled ${ }^{13} \mathrm{C} \mathrm{NMR}\left(\mathrm{C}_{6} \mathrm{D}_{6},{ }^{1} \mathrm{~J}_{\mathrm{CH}}\right.$ in $\left.\mathrm{Hz}\right): \delta 188.4$ (ipso-carbon of $\left.\mathrm{C}_{6} \mathrm{H}_{5}, \mathrm{~s}\right), 133.7,128.7,126.7\left(\mathrm{C}_{6} \mathrm{H}_{5}, \mathrm{~d}, 169\right), 118.5,118.0$ (proximal 
and distal carbons of $\left.\mathrm{C}_{5} \mathrm{H}_{4}, \mathrm{~d}, 169\right), 110.5$ (bridgehead carbon, s), $60.5\left(\mathrm{NCMe}_{3}\right.$, s), $33.8\left(\mathrm{NCMe}_{3}, \mathrm{q}, 124\right), 1.51\left(\mathrm{SiMe}_{2}, \mathrm{q}, 118\right)$.

\section{(b) Synthesis of $\left[\left(\mathrm{C}_{5} \mathrm{H}_{4}\right) \mathrm{SiMe}_{2}(\mathrm{~N}-\mathrm{t}-\mathrm{Bu})\right] \mathrm{Zr}\left(\mathrm{C}_{6} \mathrm{H}_{5}\right)_{2}$}

A $0.503 \mathrm{~g}$ sample $(1.41 \mathrm{mmol})$ of $\left\{\left[\left(\mathrm{C}_{5} \mathrm{H}_{4}\right) \mathrm{SiMe}_{2}(\mathrm{~N}-\mathrm{t}-\mathrm{Bu})\right] \mathrm{ZrCl}(\mu-\mathrm{Cl})\right\}_{2}$ was placed in a two neck round bottom flask with a cylindrical glass extension capped with a suba-seal septum attached to one neck. Diethyl ether (ca. 30 $\mathrm{mL}$ ) was added by vacuum distillation. The reaction mixture was then cooled in a liquid $\mathrm{N}_{2} / 2$-propanol bath. While stirring under a $\mathrm{N}_{2}$ flush, $1.57 \mathrm{~mL}$ of a 1.8M THF solution of $\mathrm{PhMgCl}$ was added dropwise over a 45 minute period. The solution was then allowed to stir for one hour and the temperature was slowly allowed to rise to $0^{\circ} \mathrm{C}$. The solvent was removed under reduced pressure and product was extracted from the remaining off-white residue with an equal amount of pentane. Removal of pentane left 0.559 (90.0\% yield) of $\left[\left(\mathrm{C}_{5} \mathrm{H}_{4}\right) \mathrm{SiMe}_{2}(\mathrm{~N}-\mathrm{t}-\mathrm{Bu})\right] \mathrm{Zr}\left(\mathrm{C}_{6} \mathrm{H}_{5}\right)_{2}$ as a light yellow residue. Note: The color of the isolated product slowly darkens, an indication that this compound is thermodynamically unstable at ambient temperature. ${ }^{1} \mathrm{H}$ NMR $\left(\mathrm{C}_{6} \mathrm{D}_{6},{ }^{3} \mathrm{~J}_{\mathrm{HH}}\right.$ in $\left.\mathrm{Hz}\right): \delta$ 7.74, 7.27, $7.21\left(\mathrm{C}_{6} \mathrm{H}_{5}, \mathrm{~m}\right), 6.34\left(\mathrm{C}_{5} \mathrm{H}_{4}, \mathrm{~s}\right), 1.24\left(\mathrm{NCMe}_{3}, \mathrm{~s}\right)$, $0.43\left(\mathrm{SiMe}_{2}\right) .{ }^{1} \mathrm{H}$ NMR $\left(\mathrm{CDCl}_{3},{ }^{3} \mathrm{~J}_{\mathrm{HH}}\right.$ in $\left.\mathrm{Hz}\right): \delta 7.40,7.37,7.04\left(\mathrm{C}_{6} \mathrm{H}_{5}, \mathrm{~m}\right), 6.43$, $6.25\left(\mathrm{C}_{5} \mathrm{H}_{4}, \mathrm{t}, 2.3\right), 1.15\left(\mathrm{NCMe}_{3}, \mathrm{~s}\right), 0.36\left(\mathrm{SiMe}_{2}, \mathrm{~s}\right) .{ }^{13} \mathrm{C}\left\{{ }^{1} \mathrm{H}\right\} \mathrm{NMR}\left(\mathrm{CDCl}_{3}\right): \delta$ 183.7 (ipso-carbon of $\left.\mathrm{C}_{6} \mathrm{H}_{5}\right), 134.6,127.7,126.8\left(\mathrm{C}_{6} \mathrm{H}_{5}\right), 121.2$, 118.0 (proximal and distal carbons of $\left.\mathrm{C}_{5} \mathrm{H}_{4}\right), 105.0$ (bridgehead carbon), $56.7\left(\mathrm{NCMe}_{3}\right), 33.6$ $\left(\mathrm{NCMe}_{3}\right), 1.43\left(\mathrm{SiMe}_{2}\right)$. 


\section{(c) Synthesis of $\left[\left(\mathrm{C}_{5} \mathrm{Me}_{4}\right) \mathrm{SiMe}_{2}(\mathrm{~N}-\mathrm{t}-\mathrm{Bu})\right] \mathrm{Zr}\left(\mathrm{C}_{6} \mathrm{H}_{5}\right)_{2}$}

A $1.00 \mathrm{~g}$ sample $(2.4 \mathrm{mmol})$ of $\left[\left(\mathrm{C}_{5} \mathrm{Me}_{4}\right) \mathrm{SiMe}_{2}(\mathrm{~N}-\mathrm{t}-\mathrm{Bu})\right] \mathrm{ZrCl}_{2}$ was placed in a two neck round bottom flask where one neck was capped with a suba-seal septum adapter. Diethyl ether (ca. $30 \mathrm{~mL}$ ) was added by vacuum distillation. The reaction mixture was then cooled in a liquid $\mathrm{N}_{2} / 2$-propanol bath. While stirring under a $\mathrm{N}_{2}$ flush, $2.7 \mathrm{~mL}$ of a $1.8 \mathrm{M}$ cyclohexane-ether solution of PhLi was added dropwise over a 45 minute period. The reaction mixture was then allowed to stir for one hour and the temperature was slowly raised to $0^{\circ} \mathrm{C}$. The solvent was removed under reduced pressure and the product was extracted with an equal amount of pentane. Removal of pentane left $0.903 \mathrm{~g}$ (74.7\% yield) of $\left[\left(\mathrm{C}_{5} \mathrm{Me}_{4}\right) \mathrm{SiMe}_{2}(\mathrm{~N}-\mathrm{t}-\mathrm{Bu})\right] \mathrm{Zr}\left(\mathrm{C}_{6} \mathrm{H}_{5}\right)_{2}$ as a light tan solid. ${ }^{1} \mathrm{H}$

NMR $\left(\mathrm{CDCl}_{3},{ }^{3} \mathrm{~J}_{\mathrm{HH}}\right.$ in $\left.\mathrm{Hz}\right): \delta 7.48,7.09,7.06\left(\mathrm{C}_{6} \mathrm{H}_{5}, \mathrm{~m}\right), 1.93,1.61\left(\mathrm{C}_{5} \mathrm{Me}_{4}, \mathrm{~s}\right), 1.29$ $\left(\mathrm{NCMe}_{3}, \mathrm{~s}\right), 0.52\left(\mathrm{SiMe}_{2}, \mathrm{~s}\right)$. Gated nondecoupled ${ }^{13} \mathrm{C} \mathrm{NMR}\left(\mathrm{CDCl}_{3},{ }^{1} \mathrm{~J}_{\mathrm{CH}}\right.$ in $\mathrm{Hz}$ ): $\delta 188.1$ (ipso-carbon of $\left.\mathrm{C}_{6} \mathrm{H}_{5}, \mathrm{~s}\right), 135.1\left(\mathrm{C}_{6} \mathrm{H}_{5}, \mathrm{~d}, 162\right), 131.7,127.4$ (proximal and distal carbons of $\left.\mathrm{C}_{5} \mathrm{Me}_{4}, \mathrm{~s}\right), 127.2,126.5\left(\mathrm{C}_{6} \mathrm{H}_{5}, \mathrm{~d}, 157\right), 97.2$ (bridgehead carbon, s), $56.8\left(\mathrm{NCMe}_{3}, \mathrm{~s}\right), 15.0,11.9\left(\mathrm{C}_{5} \mathrm{Me}_{4}, \mathrm{q}, 121,126\right), 33.5\left(\mathrm{NCMe}_{3}, \mathrm{q}, 124\right)$, $6.44\left(\mathrm{SiMe}_{2}, \mathrm{q}, 121\right)$.

\section{Diphenylacetylene Coupling Reactions}

\section{(a) Synthesis of $\left[\left(\mathrm{C}_{5} \mathrm{H}_{4}\right) \mathrm{SiMe}_{2}(\mathrm{~N}-\mathrm{t}-\mathrm{Bu})\right] \operatorname{Ti}\left[\left(\mathrm{C}_{6} \mathrm{H}_{4}\right) \mathrm{C}(\mathrm{Ph})=\mathrm{C}(\mathrm{Ph})\right]$}

A $0.492 \mathrm{~g}$ sample $(1.24 \mathrm{mmol})$ of $\left[\left(\mathrm{C}_{5} \mathrm{H}_{4}\right) \mathrm{SiMe}_{2}(\mathrm{~N}-\mathrm{t}-\mathrm{Bu})\right] \mathrm{Ti}\left(\mathrm{C}_{6} \mathrm{H}_{5}\right)_{2}$ was combined with $0.222 \mathrm{~g}(1.24 \mathrm{mmol})$ of diphenylacetylene in a $100 \mathrm{~mL}$ round bottom flask, which was attached to a filter frit assembly. Cyclohexane (ca. $20 \mathrm{~mL}$ ) was added via vacuum transfer and the reaction mixture was stirred at $80^{\circ} \mathrm{C}$ overnight. Solvent was removed under reduced pressure and the dark 
red product residue was washed with hexamethyldisiloxane. Recrystallization by slow removal of pentane from a concentrated solution yielded reddish-orange crystals of $\quad\left[\left(\mathrm{C}_{5} \mathrm{H}_{4}\right) \mathrm{SiMe}_{2}(\mathrm{~N}-\mathrm{t}-\right.$ $\mathrm{Bu})] \operatorname{Ti}\left[\left(\mathrm{C}_{6} \mathrm{H}_{4}\right) \mathrm{C}(\mathrm{Ph})=\mathrm{C}(\mathrm{Ph})\right]$ suitable for an X-ray crystallographic analysis. Anal. Calcd. for $\mathrm{C}_{31} \mathrm{H}_{33} \mathrm{NSiTi}$ (495.58): C, 75.12; H, 6.71; N, 2.82. Found: C, 75.69; $\mathrm{H}, 6.38: \mathrm{N}, 2.72$. The NMR data are given in Table 1.

\section{(b) Synthesis of $\left[\left(\mathrm{C}_{5} \mathrm{Me}_{4}\right) \mathrm{SiMe}_{2}(\mathrm{~N}-\mathrm{t}-\mathrm{Bu})\right] \mathrm{Zr}\left[\left(\mathrm{C}_{6} \mathrm{H}_{4}\right) \mathrm{C}(\mathrm{Ph})=\mathrm{C}(\mathrm{Ph})\right]$}

A $1.00 \mathrm{~g}$ sample $(2.02 \mathrm{mmol})$ of $\left[\left(\mathrm{C}_{5} \mathrm{Me}_{4}\right) \mathrm{SiMe}_{2}(\mathrm{~N}-\mathrm{t}-\mathrm{Bu})\right] \mathrm{Zr}\left(\mathrm{C}_{6} \mathrm{H}_{5}\right)_{2}$ was combined with $0.360 \mathrm{~g}(2.02 \mathrm{mmol})$ of diphenylacetylene in a $100 \mathrm{~mL}$ round bottom flask. Cyclohexane ( $c a .50 \mathrm{~mL}$ ) was added via vacuum transfer and the reaction mixture was stirred at $60^{\circ} \mathrm{C}$ for two days. Solvent was removed under reduced pressure. Repeated washings with hexamethyldisiloxane yielded $\left[\left(\mathrm{C}_{5} \mathrm{Me}_{4}\right) \mathrm{SiMe}_{2}(\mathrm{~N}-\mathrm{t}-\mathrm{Bu})\right] \mathrm{Zr}\left[\left(\mathrm{C}_{6} \mathrm{H}_{4}\right) \mathrm{C}(\mathrm{Ph})=\mathrm{C}(\mathrm{Ph})\right]$ as a dry off-white solid. Anal. Calcd. for $\mathrm{C}_{35} \mathrm{H}_{41} \mathrm{NSiZr}$ (595.02): $\mathrm{C}, 70.64 ; \mathrm{H}, 6.94 ; \mathrm{N}, 2.35$. Found: $\mathrm{C}$, 65.14; H, 6.46; N, 1.11. The NMR data are summarized in Table 2. 
Table 1. ${ }^{1} \mathrm{H}$ and ${ }^{13} \mathrm{C}$ NMR data for $\left[\left(\mathrm{C}_{5} \mathrm{H}_{4}\right) \mathrm{SiMe}_{2}(\mathrm{~N}-\mathrm{t}-\mathrm{Bu})\right] \mathrm{Ti}\left[\left(\mathrm{C}_{6} \mathrm{H}_{4}\right) \mathrm{C}(\mathrm{Ph})=\mathrm{C}(\mathrm{Ph})\right]$. Solvent: $\mathrm{CDCl}_{3}$

Peak Assignment

${ }^{1} \mathrm{H}$ NMR

${ }^{13} \mathrm{C}$ NMR

$\mathrm{SiMe}_{2}$

$0.49 ; 0.59$

$0.75 ; 1.01$

$\mathrm{NCMe}_{3}$

1.58

34.0

$\mathrm{C}_{5} \mathrm{H}_{4}$

$5.55 ; 6.20$

126.0; 126.4

$7.03 ; 7.47$

121.8; 122.05

$\mathrm{NCMe}_{3}$

60.1

$\mathrm{C}^{\mathrm{a}}$

107.9

$\mathrm{C}_{6} \mathrm{H}_{4}$

6.50

126.5

6.83

124.7

6.96

128.2

7.00

127.4

$\mathrm{C}_{6} \mathrm{H}_{5}$

6.70

131.05

6.75

125.7

6.83

123.7

7.05

129.8

7.13

126.2

7.18

127.8

ipso-C

138.9

ipso-C

144.4

Ti- $\mathrm{C}=\mathrm{C}$

147.9; 145.8

Ti-C

206.1; 193.7

a $\mathrm{C}_{\mathrm{b}}$ corresponds to the bridgehead $\mathrm{C}$ attached to $\mathrm{Si}$. 
Table 2. ${ }^{1} \mathrm{H}$ and ${ }^{13} \mathrm{C}$ NMR data for $\left[\left(\mathrm{C}_{5} \mathrm{Me}_{4}\right) \mathrm{SiMe}_{2}(\mathrm{~N}-\mathrm{t}-\mathrm{Bu})\right] \mathrm{Zr}\left[\left(\mathrm{C}_{6} \mathrm{H}_{4}\right) \mathrm{C}(\mathrm{Ph})=\mathrm{C}(\mathrm{Ph})\right]$.

Solvent: $\mathrm{CDCl}_{3}$

Peak Assignment

$\mathrm{SiMe}_{2}$

$\mathrm{NCMe}_{3}$

$\mathrm{C}_{5} \mathrm{Me}_{4}$

$\mathrm{NCMe}_{3}$

$\mathrm{C}_{\mathrm{b}}^{\mathrm{a}}$

$\mathrm{C}_{5} \mathrm{Me}_{4}$

$\mathrm{C}_{6} \mathrm{H}_{4}$

$\mathrm{C}_{6} \mathrm{H}_{5}$

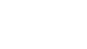

$\mathrm{Zr}-\mathrm{C}$

a $\mathrm{C}_{\mathrm{b}}$ corresponds to the bridgehead $\mathrm{C}$ attached to $\mathrm{Si}$.

$\begin{array}{ll}{ }^{1} \mathrm{H} \text { NMR } & { }^{13} \mathrm{C} \text { NMR } \\ 0.53 ; 0.61 & 6.36 ; 6.51 \\ 1.54 & 33.7 \\ 1.52 ; 1.95 & 13.3 ; 12.2 \\ 1.97 ; 2.22 & 11.45 ; 13.9\end{array}$

56.2

97.4

$127.9 ; 128.6$

$132.7 ; 132.8$

$6.55 \quad 126.9$

$6.79 \quad 123.2$

$6.96 \quad 127.2$

$7.01 \quad 128.1$

$6.86 \quad 127.8$

$6.94 \quad 124.8$

$6.98 \quad 130.1$

$7.12 \quad 125.7$

$7.18 \quad 127.6$

$7.22 \quad 133.1$

$\begin{array}{ll}\text { ipso-C } & 140.9\end{array}$

ipso-C 144.7

$150.5 ; 146.3$

197.2; 186.7 


\section{X-Ray Structural Analysis of $\left[\left(\mathrm{C}_{5} \mathrm{H}_{4}\right) \mathrm{SiMe}_{2}(\mathrm{~N}-\mathrm{t}-\mathrm{Bu})\right] \mathrm{Ti}\left(\mathrm{C}_{6} \mathrm{H}_{4} \mathrm{C}(\mathrm{Ph})=\mathrm{C}(\mathrm{Ph})\right]$.}
A reddish
orange
crystal of
$\left[\left(\mathrm{C}_{5} \mathrm{H}_{4}\right) \mathrm{SiMe}_{2}(\mathrm{~N}-\mathrm{t}-\right.$ $\mathrm{Bu})] \operatorname{Ti}\left[\left(\mathrm{C}_{6} \mathrm{H}_{4}\right) \mathrm{C}(\mathrm{Ph})=\mathrm{C}(\mathrm{Ph})\right]$ was sealed in a glass capillary tube under a nitrogen atmosphere and then optically aligned on the goniostat of a Siemens P4 automated X-ray diffractometer. The reflections that were used for the unit cell determination were located and indexed by the automatic peak search routine provided with XSCANS. ${ }^{36}$ An I-centered monoclinic cell was originally used for purposes of data collection and then converted to the conventional C-centered cell prior to performing the structural analysis. The lattice parameters and orientation matrix for the I-centered cell were calculated from a non-linear least-squares fit of the orientation angles of 30 reflections at $22{ }^{\circ} \mathrm{C}$. The systematic absences for $\{\mathrm{h} \mathrm{k} l\}$ data with $\mathrm{h}+\mathrm{k}+1=2 \mathrm{n}$ +1 absent and $\{h \quad 01\}$ data with $h=2 n+1$ data absent are consistent with the space groups Ia and $\mathrm{I} 2 / \mathrm{a}$, which correspond to nonstandard settings of $\mathrm{Cc}_{\mathrm{C}}\left(\mathrm{C}_{\mathrm{S}}{ }^{4}\right.$, No. 9) and $C 2 / c\left(C_{2 h}{ }^{6}\right.$, No. 15) ), respectively. Of these two choices the results of the structural analysis confirmed that the centrosymmetric case to be the correct one. The lattice parameters and other pertinent crystallographic information are summarized in Table 3.

Intensity data were measured with graphite-monochromatic Mo-K $\alpha$ radiation $(\lambda=0.71073 \AA)$ and variable $\omega$ scans $\left(2-10^{\circ} / \mathrm{min}\right)$. Background counts were measured at the beginning and at the end of each scan with the crystal and counter kept stationary. The intensities of three standard reflections, which were measured after every 100 reflections, showed no indication of crystal decomposition or sample movement. The raw data were corrected for Lorentz-polarization effects. 
Initial coordinates for the non-hydrogen atoms were determined by a combination of direct methods and difference Fourier calculations performed with the algorithms provided in SHELXTL-IRIS operating on a Silicon Graphics Iris Indigo workstation. The hydrogen atom positions were idealized with isotropic temperature factors set at 1.2 times that of the adjacent carbon. The positions of the methyl hydrogens were optimized by a rigid rotating group refinement with idealized tetrahedral angles. Full-matrix least-squares refinement with SHELXL-93, ${ }^{37}$ based upon the minimization of $\sum \mathrm{w}_{\mathrm{i}}\left|\mathrm{F}_{\mathrm{o}}^{2}-\mathrm{F}_{\mathrm{c}}{ }^{2}\right|^{2}$ with weighting given by the expression $\mathrm{w}_{\mathrm{i}}^{-1}=\left[\sigma^{2}\left(\mathrm{~F}_{\mathrm{o}}{ }^{2}\right)+\right.$ $\left.(0.0586 \mathrm{P})^{2}\right]$ where $\mathrm{P}=\left(\operatorname{Max}\left(\mathrm{F}_{\mathrm{o}}^{2}, 0\right)+2 \mathrm{~F}_{\mathrm{c}}^{2}\right) / 3$, converged to give the values of the final discrepancy indices ${ }^{38}$ provided in Table 3. 
Table 3. Crystallographic Data for the Structural Analysis of $\left[\left(\mathrm{C}_{5} \mathrm{H}_{4}\right) \mathrm{SiMe}_{2}(\mathrm{~N}-\mathrm{t}-\mathrm{Bu})\right] \mathrm{Ti}\left(\mathrm{C}_{6} \mathrm{H}_{4} \mathrm{C}(\mathrm{Ph})=\mathrm{C}(\mathrm{Ph})\right]$.

A. Crystal Data

emp. formula

color

crystal dimensions, $\mathrm{mm}$

crystal system

space group

a, $\check{A}$

$\mathrm{b}, \check{A}$

$c, \AA$

$\beta, \operatorname{deg}$

Volume, $\AA^{3}$

Z

formula weight, amu

calc density, $\mathrm{g} / \mathrm{cm}^{3}$

$\mu, \mathrm{cm}^{-1}$

$\mathrm{F}\left(\begin{array}{lll}0 & 0 & 0\end{array}\right)$

temperature, ${ }^{\circ} \mathrm{C}$

B. Data Collection and Structural Analyses

scan type

scan rate, $\mathrm{deg} / \mathrm{min}$

$2 \theta$ range, deg

$2 \theta$ range, centered refls

reflections sampled

no. of refl. collected

no. of unique data

no. of data, $\mathrm{I}>2 \sigma(\mathrm{I})$

$R$ indices, $\mathrm{I}>2 \sigma(\mathrm{I})$

$\mathrm{R}$ indices, all data

$\sigma_{1}, \mathrm{GOF}$

no. of variables

max. diff. peak and hole

$\mathrm{C}_{31} \mathrm{H}_{33} \mathrm{NSiTi}$
red orange
$0.15 \times 0.34 \times 0.36$
monoclinic
$\mathrm{C} 2 / \mathrm{c}$
$30.993(3)$
$11.418(2)$
$16.616(2)$
$109.55(1)$
$5541.1(11)$
8
495.57
1.188
3.71
2096
$22 \pm 1$

$\omega$, variable

$2.0-10.0$

$3.0-40.0$

$10-25$

h $(-18 \leq \mathrm{h} \leq 33)$

$\mathrm{k}(-12 \leq \mathrm{k} \leq 1)$

$1(-17 \leq 1 \leq 17)$

4287

$3558\left(R_{\text {int }}=0.0473\right)$

1769

$\mathrm{R} 1=0.0636$

$\mathrm{wR} 2=0.1206$

$\mathrm{R} 1=0.1627$

$\mathrm{wR} 2=0.1896$

1.020

312

$0.208,-0.221$ 
Table 4. Interatomic Distances $(\AA)$ and Bond Angles for $\left[\left(\mathrm{C}_{5} \mathrm{H}_{4}\right) \mathrm{SiMe}_{2}(\mathrm{~N}-\mathrm{t}-\mathrm{Bu})\right] \mathrm{Ti}\left(\mathrm{C}_{6} \mathrm{H}_{4} \mathrm{C}(\mathrm{Ph})=\mathrm{C}(\mathrm{Ph})\right]^{\mathrm{a}}$

A. Interatomic Distances

$\begin{array}{llll}\text { Ti-N } & 1.915(5) & \text { Ti-Cp(c) } & 2.025 \\ \text { Ti-C(12) } & 2.081(7) & \text { Ti-C(15) } & 2.103(6) \\ \text { Ti-C(1) } & 2.299(6) & \text { Ti-C(2) } & 2.332(2) \\ \text { Ti-C(3) } & 2.379(7) & \text { Ti-C(4) } & 2.410(7) \\ \text { Ti-C(5) } & 2.332(7) & \mathrm{N}-\mathrm{C}(8) & 1.489(7) \\ \text { Si-N } & 1.744(5) & \mathrm{Si}-\mathrm{C}(1) & 1.855(8) \\ \text { Si-C(6) } & 1.850(8) & \mathrm{Si}-\mathrm{C}(7) & 1.845(7) \\ \mathrm{C}(1)-\mathrm{C}(2) & 1.416(9) & \mathrm{C}(2)-\mathrm{C}(3) & 1.380(9) \\ \mathrm{C}(3)-\mathrm{C}(4) & 1.383(10) & \mathrm{C}(4)-\mathrm{C}(5) & 1.391(10) \\ \mathrm{C}(5)-\mathrm{C}(1) & 1.411(9) & \mathrm{C}(8)-\mathrm{C}(9) & 1.516(8) \\ \mathrm{C}(8)-\mathrm{C}(10) & 1.530(9) & \mathrm{C}(8)-\mathrm{C}(11) & 1.548(8) \\ \mathrm{C}(12-\mathrm{C}(13) & 1.404(8) & \mathrm{C}(13)-\mathrm{C}(14) & 1.511(8) \\ \mathrm{C}(14)-\mathrm{C}(15) & 1.355(8) & \mathrm{C}(12)-\mathrm{C}(16) & 1.390(8) \\ \mathrm{C}(13)-\mathrm{C}(19) & 1.381(8) & \mathrm{C}(14)-\mathrm{C}(20) & 1.511(8) \\ \mathrm{C}(15)-\mathrm{C}(26) & 1.469(8) & \mathrm{C}(16)-\mathrm{C}(17) & 1.381(8) \\ \mathrm{C}(17)-\mathrm{C}(18) & 1.363(8) & \mathrm{C}(18)-\mathrm{C}(19) & 1.386(9)\end{array}$

B. Bond Angles

$\begin{array}{llll}\mathrm{Cp}(\mathrm{c})-\mathrm{Ti}-\mathrm{N} & 108.4 & \mathrm{Cp}(\mathrm{c})-\mathrm{Ti}-\mathrm{C}(12) & 115.3 \\ \mathrm{Cp}(\mathrm{c})-\mathrm{Ti}-\mathrm{C}(15) & 118.2 & \mathrm{~N}-\mathrm{Ti}-\mathrm{C}(12) & 110.8(2) \\ \mathrm{N}-\mathrm{Ti}-\mathrm{C}(15) & 117.5(2) & \mathrm{C}(12-\mathrm{Ti}-\mathrm{C}(15) & 85.1(3) \\ \mathrm{C}(12)-\mathrm{Ti}-\mathrm{Si} & 129.8(2) & \mathrm{C}(15)-\mathrm{Ti}-\mathrm{Si} & 137.8(2) \\ \text { N-Si-C(1) } & 93.4(3) & \mathrm{N}-\mathrm{Si}-\mathrm{C}(7) & 116.0(3) \\ \text { N-Si-C(6) } & 113.4(3) & \mathrm{C}(1)-\mathrm{Si}-\mathrm{C}(6) & 110.1(4) \\ \mathrm{C}(1)-\mathrm{N}-\mathrm{C}(7) & 111.8(4) & \mathrm{C}(6)-\mathrm{Si}-\mathrm{C}(7) & 111.0(4) \\ \text { Si-N-Ti } & 103.4(2) & \mathrm{C}(8)-\mathrm{N}-\mathrm{Si} & 126.4(4) \\ \mathrm{C}(8)-\mathrm{N}-\mathrm{Ti} & 129.7(4) & \mathrm{C}(2)-\mathrm{C}(1)-\mathrm{C}(5) & 104.2(6) \\ \mathrm{C}(2)-\mathrm{C}(1)-\mathrm{Si} & 121.8(6) & \mathrm{C}(5)-\mathrm{C}(1)-\mathrm{Si} & 121.5(6) \\ \mathrm{C}(1)-\mathrm{C}(2)-\mathrm{C}(3) & 109.4(7) & \mathrm{C}(2)-\mathrm{C}(3)-\mathrm{C}(4) & 109.2(8) \\ \mathrm{C}(3)-\mathrm{C}(4)-\mathrm{C}(5) & 106.5(8) & \mathrm{C}(4)-\mathrm{C}(5)-\mathrm{C}(1) & 110.7(8)\end{array}$




$\begin{array}{llll}\text { N-C(8)-C(9) } & 111.3(6) & \mathrm{N}-\mathrm{C}(8)-\mathrm{C}(10) & 110.0(6) \\ \mathrm{N}-\mathrm{C}(8)-\mathrm{C}(11) & 108.9(5) & \mathrm{C}(9)-\mathrm{C}(8)-\mathrm{C}(10) & 109.9(6) \\ \mathrm{C}(9)-\mathrm{C}(8)-\mathrm{C}(11) & 108.3(6) & \mathrm{C}(10)-\mathrm{C}(8)-\mathrm{C}(11) & 108.4(6) \\ \mathrm{C}(13)-\mathrm{C}(12)-\mathrm{Ti} & 108.4(5) & \mathrm{C}(16)-\mathrm{C}(12)-\mathrm{Ti} & 133.2(5) \\ \mathrm{C}(13)-\mathrm{C}(12)-\mathrm{C}(16) & 118.2(6) & \mathrm{C}(12)-\mathrm{C}(13)-\mathrm{C}(14) & 118.1(6) \\ \mathrm{C}(12)-\mathrm{C}(13)-\mathrm{C}(19) & 120.3(6) & \mathrm{C}(14)-\mathrm{C}(13)-\mathrm{C}(19) & 121.7(6) \\ \mathrm{C}(13)-\mathrm{C}(14)-\mathrm{C}(15) & 119.0(6) & \mathrm{C}(13)-\mathrm{C}(14)-\mathrm{C}(20) & 116.2(5) \\ \mathrm{C}(15)-\mathrm{C}(14)-\mathrm{C}(20) & 124.9(6) & \mathrm{C}(14)-\mathrm{C}(15)-\mathrm{C}(26) & 124.9(6) \\ \mathrm{C}(14)-\mathrm{C}(15)-\mathrm{Ti} & 109.0(5) & \mathrm{C}(26)-\mathrm{C}(15)-\mathrm{Ti} & 125.9(5) \\ \mathrm{C}(12)-\mathrm{C}(16)-\mathrm{C}(17) & 121.4(7) & \mathrm{C}(16)-\mathrm{C}(17)-\mathrm{C}(18) & 119.4(7) \\ \mathrm{C}(17)-\mathrm{C}(18)-\mathrm{C}(19) & 121.1(7) & \mathrm{C}(13)-\mathrm{C}(19)-\mathrm{C}(18) & 119.7(6) \\ & & & \\ & \end{array}$




\section{Results and Discussion}

Preparation of $\left[\left(\mathrm{C}_{5} \mathrm{R}_{4}\right) \mathrm{SiMe}_{2}(\mathrm{~N}-\mathrm{t}-\mathrm{Bu})\right] \mathrm{M}\left(\mathrm{C}_{6} \mathrm{H}_{5}\right)_{2}$ where $\mathrm{R}=\mathrm{H}$, Me; $\mathrm{M}=\mathrm{Ti}$, $\mathrm{Zr}$.

The series of ansa-mono- and ansa-tetramethylcyclopentadienyl metal diphenyl complexes were prepared by the stoichiometric metathetical reaction of the corresponding metal dichloride precursor with two equiv. of an appropriate phenylating reagent. The phenylating reagents that were considered included phenyllithium, phenylmagnesiumbromide, and phenylmagnesiumchloride. The utilization of a specific phenyl reagent is not general for the preparation of these diphenyl complexes, but instead is dependent on the choice of the dichloride precursor.

(a) Preparation of the ansa-monocyclopentadienyl Ti(IV) diphenyl complex,

\section{$\left[\left(\mathrm{C}_{5} \mathrm{H}_{4}\right) \mathrm{SiMe}_{2}(\mathrm{~N}-\mathrm{t}-\mathrm{Bu})\right] \mathrm{Ti}\left(\mathrm{C}_{6} \mathrm{H}_{5}\right)_{2}$}

The stoichiometric reaction of $\left[\left(\mathrm{C}_{5} \mathrm{H}_{4}\right) \mathrm{SiMe}_{2}(\mathrm{~N}-\mathrm{t}-\mathrm{Bu})\right] \mathrm{TiCl}_{2}$ with two equivalents of $\mathrm{PhMgBr}$ was carried out in ether at $-40^{\circ} \mathrm{C}$, eq. 14 . As the reaction temperature increased to room temperature, the color of the solution turned from orange to deep red. The product, $\left[\left(\mathrm{C}_{5} \mathrm{H}_{4}\right) \mathrm{SiMe}_{2}(\mathrm{~N}-\mathrm{t}-\right.$ $\mathrm{Bu})] \operatorname{Ti}\left(\mathrm{C}_{6} \mathrm{H}_{5}\right)_{2}$, was extracted with pentane and in $56 \%$ yield as a semicrystalline reddish-orange solid.

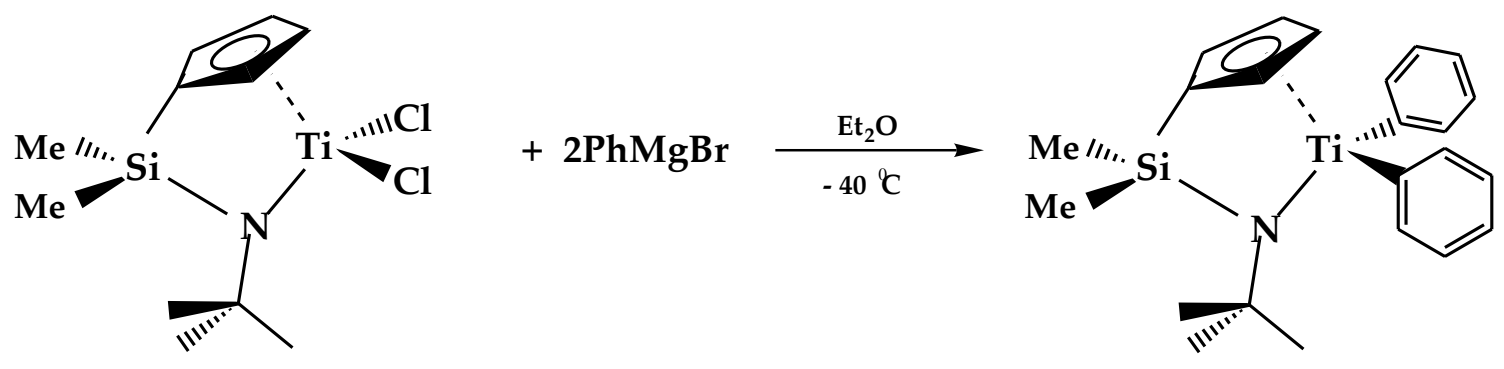

(eq. 14) 
The identity of $\left[\left(\mathrm{C}_{5} \mathrm{H}_{4}\right) \mathrm{SiMe}_{2}(\mathrm{~N}-\mathrm{t}-\mathrm{Bu})\right] \mathrm{Ti}\left(\mathrm{C}_{6} \mathrm{H}_{5}\right)_{2}$ was verified by solution ${ }^{1} \mathrm{H}$ and ${ }^{13} \mathrm{C}$ NMR measurements in $\mathrm{C}_{6} \mathrm{D}_{6}$. Both sets of NMR data are consistent with the presence of mirror symmetry in solution. The ${ }^{1} \mathrm{H}$ NMR spectrum contains multiplets at $\delta 8.14$ and 7.09 for the ortho- and metaprotons and a signal at $\delta 7.20$ for the para- protons of the phenyl substituents. The ${ }^{1} \mathrm{H}$ NMR signal at $\delta 7.20$ is obscured somewhat by the proton resonance of residual $\mathrm{C}_{6} \mathrm{D}_{5} \mathrm{H}$. Two pseudo triplets for the distal and proximal protons of the cyclopentadienyl group are centered at $\delta 6.56$ and $\delta 5.27$. The singlet at $\delta$ 1.58 represents the nine methyl protons of the t-butyl amido substituent. A singlet for the six methyl protons of the $\mathrm{SiMe}_{2}$ bridge is found at $\delta 0.61$.

The corresponding ${ }^{13} \mathrm{C}\left\{{ }^{1} \mathrm{H}\right\}$ NMR spectrum exhibits the expected number of ten carbon resonances. The values for the ${ }^{1} \mathrm{~J}_{\mathrm{CH}}$ coupling constants were obtained from the measurements of the gated non-decoupled ${ }^{13} \mathrm{C} N \mathrm{NM}$ spectrum. The ${ }^{13} \mathrm{C}$ NMR data for $\left[\left(\mathrm{C}_{5} \mathrm{H}_{4}\right) \mathrm{SiMe}_{2}(\mathrm{~N}-\mathrm{t}-\mathrm{Bu})\right] \mathrm{Ti}\left(\mathrm{C}_{6} \mathrm{H}_{5}\right)_{2}$ are summarized in Table 5. The two methyl carbons of the $\mathrm{SiMe}_{2}$ bridge appear as a quartet at $\delta 1.51\left({ }^{1} \mathrm{~J}_{\mathrm{CH}}=118 \mathrm{~Hz}\right)$; the three methyl carbons of the tert-butyl substituent and the quaternary carbon of the amido functionality exhibit a quartet at $\delta 33.8\left({ }^{1} \mathrm{~J}_{\mathrm{CH}}=124 \mathrm{~Hz}\right)$ and a singlet at $\delta 60.5$, respectively. The cyclopentadienyl group displays a singlet at $\delta 110.5$ for the bridgehead carbon and a pair of doublet of multiplets at $\delta 118.5\left({ }^{1} \mathrm{~J}_{\mathrm{CH}}=169 \mathrm{~Hz}\right)$ and $\delta 118.0\left({ }^{1} \mathrm{~J}_{\mathrm{CH}}=\right.$ $169 \mathrm{~Hz}$ ) for the proximal and distal cyclopentadienyl ring carbons. The phenyl carbons appear as doublets at $\delta 126.7$ and 133.7 with a ${ }^{1} \mathrm{~J}_{\mathrm{CH}}=169 \mathrm{~Hz}$ for the meta-, and ortho-carbons and a doublet at $\delta 128.7$ with ${ }^{1} \mathrm{~J}_{\mathrm{CH}}=169 \mathrm{~Hz}$ for the para-carbons of the phenyl substituents; the singlet at $\delta 188.4$ represents the carbon atoms directly attached to the metal. 


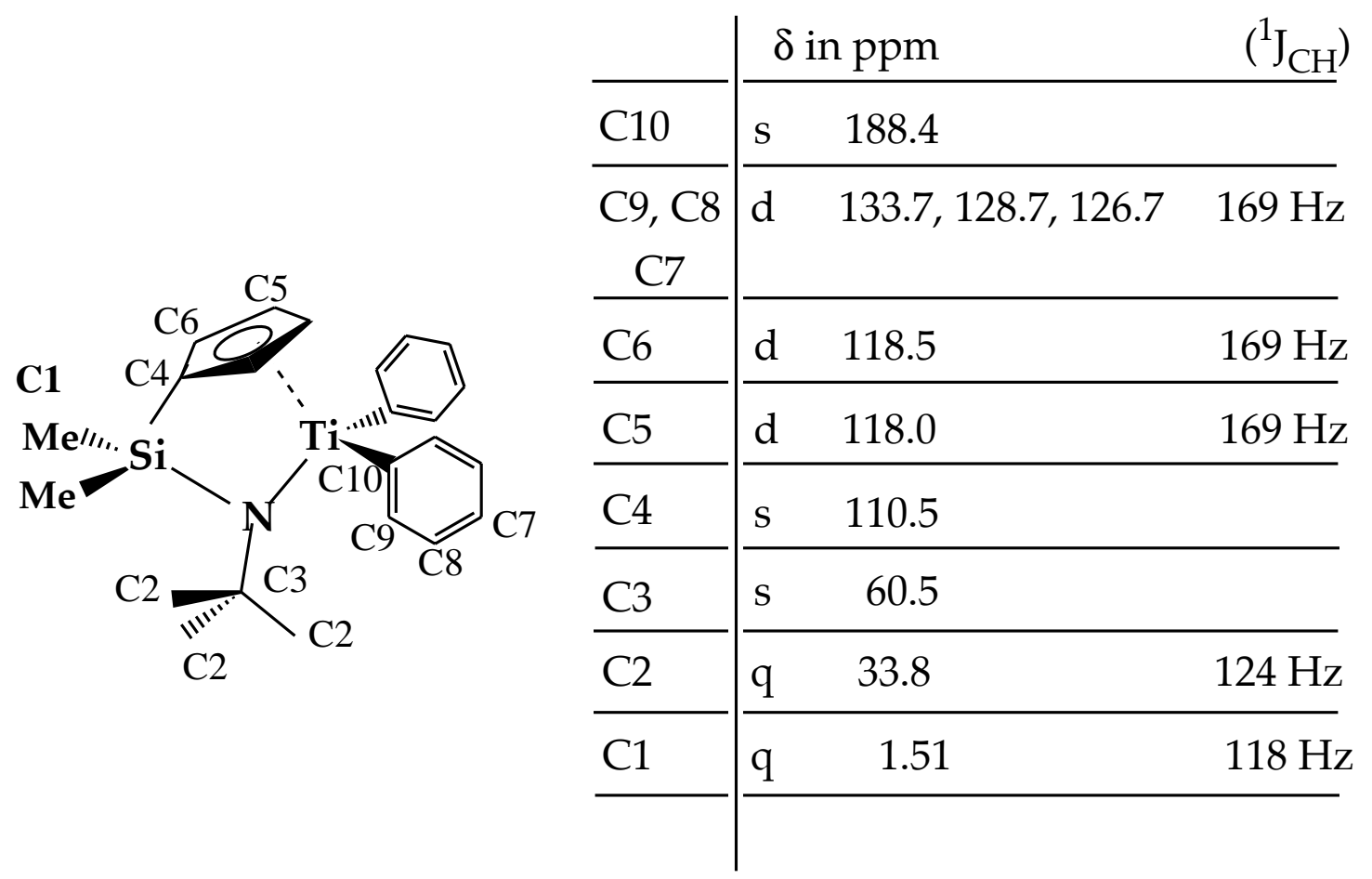

Table 5. ${ }^{13} \mathrm{C}$ NMR data for $\left[\left(\mathrm{C}_{5} \mathrm{H}_{4}\right) \mathrm{SiMe}_{2}(\mathrm{~N}-\mathrm{t}-\mathrm{Bu})\right] \mathrm{Ti}\left(\mathrm{C}_{6} \mathrm{H}_{5}\right)_{2}$.

(b) Preparation of the ansa-monocyclopentadienyl $\mathrm{Zr}(\mathrm{IV})$ diphenyl complex, $\left[\left(\mathrm{C}_{5} \mathrm{H}_{4}\right) \mathrm{SiMe}_{2}(\mathrm{~N}-\mathrm{t}-\mathrm{Bu})\right] \mathrm{Zr}\left(\mathrm{C}_{6} \mathrm{H}_{5}\right)_{2}$

The metathetical reaction of $\left[\left(\mathrm{C}_{5} \mathrm{H}_{4}\right) \mathrm{SiMe}_{2}(\mathrm{~N}-\mathrm{t}-\mathrm{Bu})\right] \mathrm{ZrCl}_{2}$ with two equivalents of $\mathrm{PhMgCl}$ similarly proceeded with the formation of the corresponding zirconium diphenyl complex, $\left[\left(\mathrm{C}_{5} \mathrm{H}_{4}\right) \mathrm{SiMe}_{2}(\mathrm{~N}-\mathrm{t}-\mathrm{Bu})\right] \mathrm{Zr}\left(\mathrm{C}_{6} \mathrm{H}_{5}\right)_{2}$, as shown in eq. 15 . The reaction was carried out at $-40^{\circ} \mathrm{C}$ in ether.

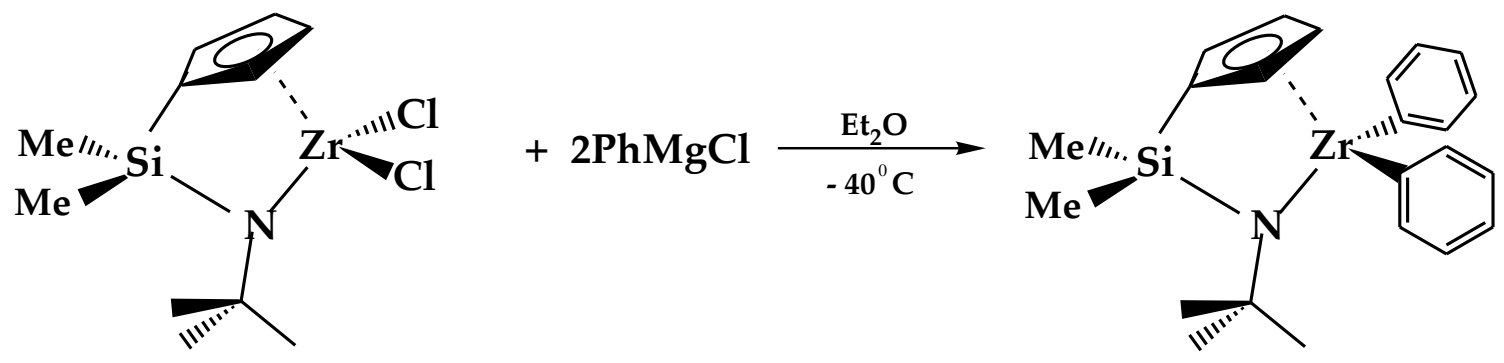

(eq. 15) 
This compound was also isolated by extraction with pentane, affording initially a light yellow residue in $90 \%$ yield. However, within a few hours this compound darkened upon standing at ambient temperature. This color change was accompanied by deterioration of the NMR spectral features for $\left[\left(\mathrm{C}_{5} \mathrm{H}_{4}\right) \mathrm{SiMe}_{2}(\mathrm{~N}-\mathrm{t}-\mathrm{Bu})\right] \mathrm{Zr}\left(\mathrm{C}_{6} \mathrm{H}_{5}\right)_{2}$.

The identity of $\left[\left(\mathrm{C}_{5} \mathrm{H}_{4}\right) \mathrm{SiMe}_{2}(\mathrm{~N}-\mathrm{t}-\mathrm{Bu})\right] \mathrm{Zr}\left(\mathrm{C}_{6} \mathrm{H}_{5}\right)_{2}$ was verified by solution ${ }^{1} \mathrm{H}$ and ${ }^{13} \mathrm{C}$ NMR measurements in $\mathrm{C}_{6} \mathrm{D}_{6}$ and $\mathrm{CDCl}_{3}$. The NMR data are consistent with the presence of mirror-symmetry in solution and show that the chemical shifts of the cyclopentadienyl ring protons are highly solvent dependent. In $\mathrm{C}_{6} \mathrm{D}_{6}$, the ortho- and meta-protons of the phenyl ligands appear at $\delta 7.74$ and 7.21 with the para-protons appearing at $\delta$ 7.27. The distal and proximal protons of the cyclopentadienyl ring exhibit only an apparent singlet at $\delta 6.34$. The singlet at $\delta 1.24$ is assigned to the t-butyl nine methyl protons of the amido functionality and the upfield singlet at $\delta 0.61$ corresponds to the six methyl protons of the $\mathrm{SiMe}_{2}$ bridge. To resolve the two resonances expected for the pairs of the distal and proximal cyclopentadienyl ring protons, the ${ }^{1} \mathrm{H}$ NMR spectrum was also measured in $\mathrm{CDCl}_{3}$. This spectrum contains three multiplets at $\delta 7.40,7.37$, and 7.04 corresponding to the phenyl ring protons, two pseudo triplets at $\delta 6.43$ and $\delta 6.25$ for the distal and proximal protons of the cyclopentadienyl ring, a singlet at $\delta 1.15$ representing the nine methyl protons of the t-butyl amido substituent and a singlet at $\delta 0.36$ for the six methyl protons of the $\mathrm{SiMe}_{2}$ bridge.

The corresponding ${ }^{13} \mathrm{C}\left\{{ }^{1} \mathrm{H}\right\} \quad \mathrm{NMR}$ spectrum of $\left[\left(\mathrm{C}_{5} \mathrm{H}_{4}\right) \mathrm{SiMe}_{2}(\mathrm{~N}-\mathrm{t}-\right.$ $\mathrm{Bu})] \mathrm{Zr}\left(\mathrm{C}_{6} \mathrm{H}_{5}\right)_{2}$, in $\mathrm{CDCl}_{3}$, exhibits the expected ten carbon resonances. The ${ }^{13} \mathrm{C}$ NMR data for $\left[\left(\mathrm{C}_{5} \mathrm{H}_{4}\right) \mathrm{SiMe}_{2}(\mathrm{~N}-\mathrm{t}-\mathrm{Bu})\right] \mathrm{Zr}\left(\mathrm{C}_{6} \mathrm{H}_{5}\right)_{2}$ are summarized in Table 6. The two methyl carbons of the $\mathrm{SiMe}_{2}$ bridge appear at $\delta 1.43$, the three methyl carbons and the quaternary carbon of the t-butyl substituent appear at $\delta 33.6$ 
and $\delta$ 56.7, respectively. The cyclopentadienyl ring carbons exhibit three resonances, with the signal at $\delta 105.0$ representing the bridgehead carbon and the downfield resonances at $\delta 121.2$ and $\delta 118.0$ corresponding to the proximal and distal carbons of the cyclopentadienyl ring. Two resonances appearing at $\delta 134.6$ and 126.8 represent the ortho- and meta-carbons of the phenyl ring with a signal at $\delta 127.7$ assigned to the para-carbons. The downfield signal at $\delta$ 183.7 is assigned to the carbon atoms of the phenyl rings directly bonded to zirconium.

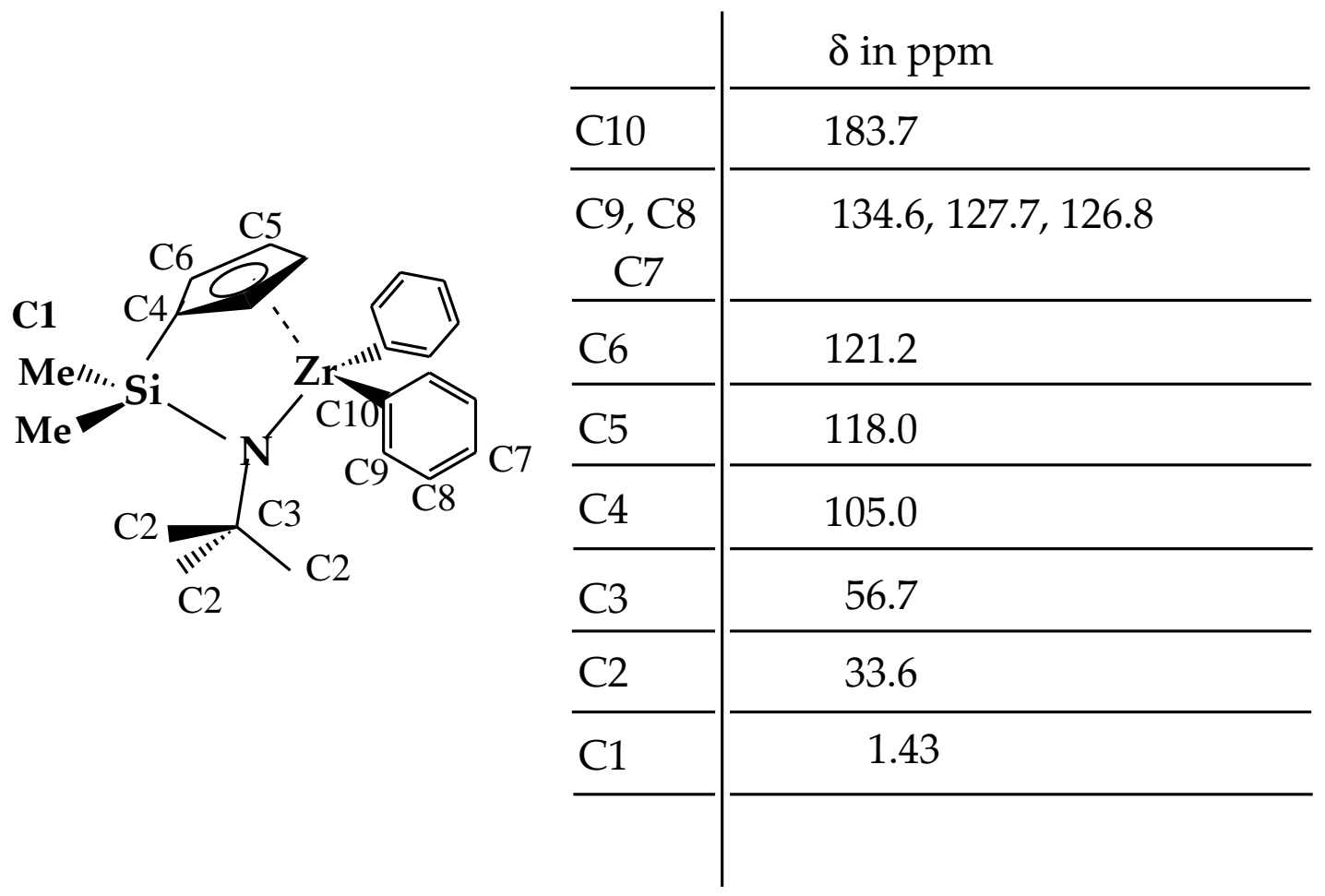

Table 6. ${ }^{13} \mathrm{C}$ NMR data for $\left[\left(\mathrm{C}_{5} \mathrm{H}_{4}\right) \mathrm{SiMe}_{2}(\mathrm{~N}-\mathrm{t}-\mathrm{Bu})\right] \mathrm{Zr}\left(\mathrm{C}_{6} \mathrm{H}_{5}\right)_{2}$. 


\section{(c) Preparation of the ansa-tetramethylcyclopentadienyl Zr(IV) diphenyl complex, $\left[\left(\mathrm{C}_{5} \mathrm{Me}_{4}\right) \mathrm{SiMe}_{2}(\mathrm{~N}-\mathrm{t}-\mathrm{Bu})\right] \mathrm{Zr}\left(\mathrm{C}_{6} \mathrm{H}_{5}\right)_{2}$}

Treatment of $\left[\left(\mathrm{C}_{5} \mathrm{Me}_{4}\right) \mathrm{SiMe}_{2}(\mathrm{~N}-\mathrm{t}-\mathrm{Bu})\right] \mathrm{ZrCl}_{2}$ with two equivalents of $\mathrm{PhLi}$, when carried out in ether at $-40^{\circ} \mathrm{C}$, proceeded cleanly with the formation of $\left[\left(\mathrm{C}_{5} \mathrm{Me}_{4}\right) \operatorname{SiMe}_{2}(\mathrm{~N}-\mathrm{t}-\mathrm{Bu})\right] \mathrm{Zr}\left(\mathrm{C}_{6} \mathrm{H}_{5}\right)_{2}$ (eq. 16). This diphenyl compound was obtained as a light tan solid in $74.7 \%$ yield and is highly soluble in pentane.
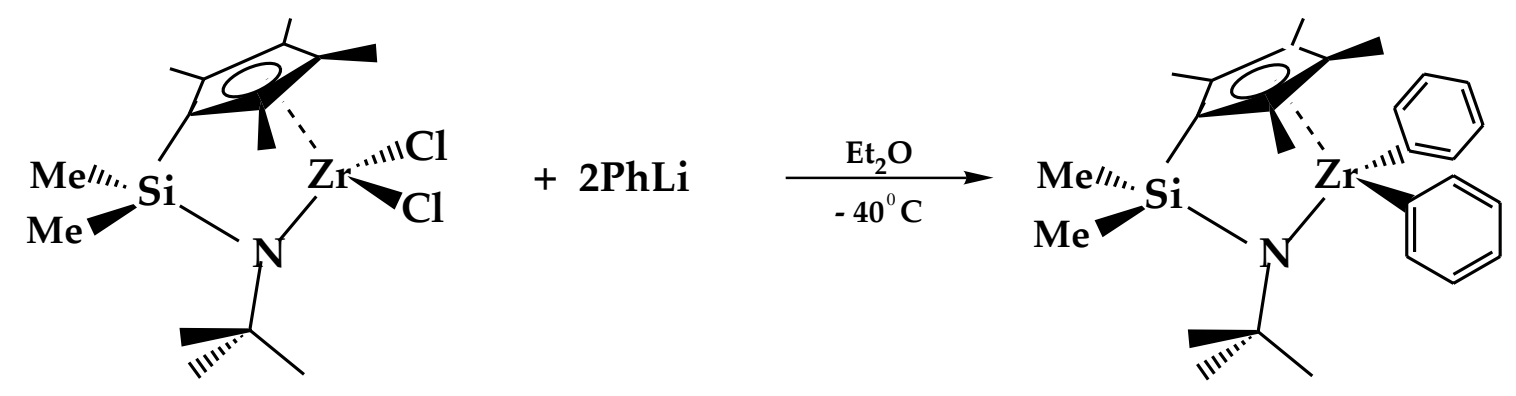

(eq. 16)

The identity of $\left[\left(\mathrm{C}_{5} \mathrm{Me}_{4}\right) \mathrm{SiMe}_{2}(\mathrm{~N}-\mathrm{t}-\mathrm{Bu})\right] \mathrm{Zr}\left(\mathrm{C}_{6} \mathrm{H}_{5}\right)_{2}$ was confirmed by solution ${ }^{1} \mathrm{H}$ and ${ }^{13} \mathrm{C}$ NMR measurements in $\mathrm{CDCl}_{3}$. The $\mathrm{NMR}$ data are consistent with the presence of mirror symmetry. The ${ }^{1} \mathrm{H}$ NMR spectrum contains multiplets at $\delta 7.48$ and 7.06 for the ortho- and meta- protons and a signal at $\delta 7.09$ for the para-protons of the phenyl ligands. The spectrum further contains two singlets at $\delta 1.93$ and $\delta 1.61$ for the distal and proximal methyl protons of the $\mathrm{C}_{5} \mathrm{Me}_{4}$ ring, a singlet at $\delta 1.29$ for the nine methyl protons of the appended t-butyl amido functionality, and an upfield singlet at $\delta 0.52$ for the six methyl protons of the $\mathrm{SiMe}_{2}$ bridge.

The ${ }^{13} \mathrm{C}\left\{{ }^{1} \mathrm{H}\right\}$ NMR spectrum exhibits the expected number of twelve carbon resonances. The values for the ${ }^{1} \mathrm{~J}_{\mathrm{CH}}$ coupling constants were obtained from the measurement of the gated non-decoupled ${ }^{13} \mathrm{C}$ NMR spectrum. The ${ }^{13} \mathrm{C}$ NMR data for $\left[\left(\mathrm{C}_{5} \mathrm{Me}_{4}\right) \mathrm{SiMe}_{2}(\mathrm{~N}-\mathrm{t}-\mathrm{Bu})\right] \mathrm{Zr}\left(\mathrm{C}_{6} \mathrm{H}_{5}\right)_{2}$ are summarized in Table 7. The two methyl carbons of the $\mathrm{SiMe}_{2}$ linkage appear as a binomial quartet 
at $\delta 6.44\left({ }^{1} \mathrm{~J}_{\mathrm{CH}}=121 \mathrm{~Hz}\right)$, the three methyl carbons of the tert-butyl substituent and the quaternary carbon of the amido functionality exhibit a quartet at $\delta 33.5$ $\left({ }^{1} \mathrm{~J}_{\mathrm{CH}}=124 \mathrm{~Hz}\right)$ and a singlet at $\delta 56.8$, respectively. The methyl carbons of the tetramethylcyclopentadienyl ring display a pair of quartets at $\delta 15.0\left({ }^{1} \mathrm{~J}_{\mathrm{CH}}=121\right.$ $\mathrm{Hz})$ and $\delta 11.9\left({ }^{1} \mathrm{~J}_{\mathrm{CH}}=126 \mathrm{~Hz}\right)$ for the proximal and distal methyl carbons. The three carbon resonances of the cyclopentadienyl ring appear as a singlet at $\delta$

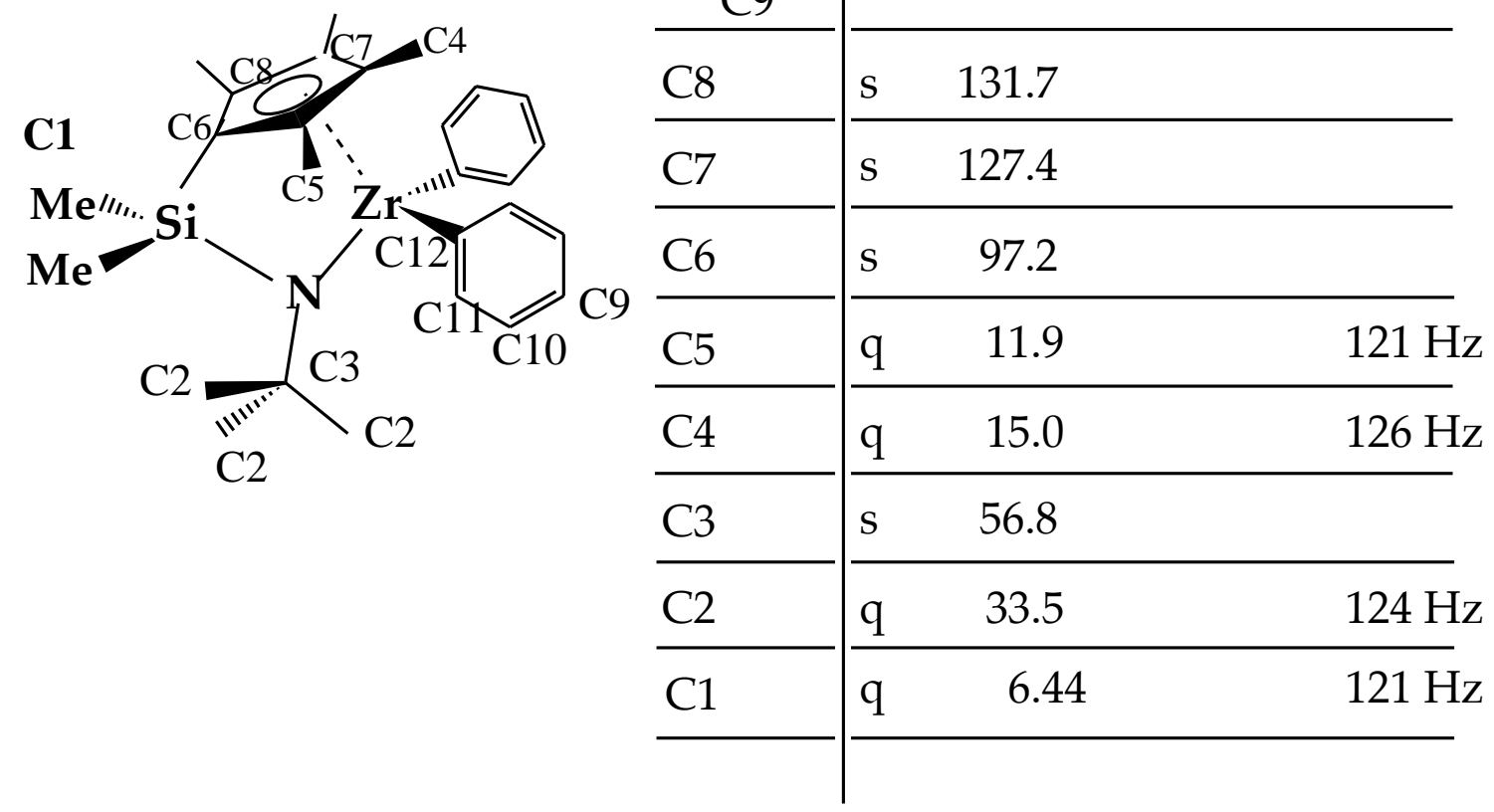

Table 7. ${ }^{13} \mathrm{C}$ NMR data for $\left[\left(\mathrm{C}_{5} \mathrm{Me}_{4}\right) \mathrm{SiMe}_{2}(\mathrm{~N}-\mathrm{t}-\mathrm{Bu})\right] \mathrm{Zr}\left(\mathrm{C}_{6} \mathrm{H}_{5}\right)_{2}$ :

97.2 for the bridgehead carbon and a pair of singlets at $\delta 131.7$ and $\delta 127.4$ representing the proximal and distal ring carbons. The phenyl carbons appear as doublets at $\delta 126.5$ and $\delta 135.1$ with a ${ }^{1} \mathrm{~J}_{\mathrm{CH}}=157 \mathrm{~Hz}$ for the ortho- and metacarbons and a doublet at $\delta 127.2\left({ }^{1} \mathrm{~J}_{\mathrm{CH}}=162 \mathrm{~Hz}\right)$ for the para-carbons. The singlet at $\delta 188.1$ represents the carbon atoms directly bonded to zirconium. 


\section{Diphenylacetylene Coupling Reactions}

The thermally-induced reactions of diphenylacetylene with a diphenyl precursor were performed in an effort to trap the benzyne intermediate and to isolate the resultant five membered metallacyclic product. Erker and coworkers ${ }^{12}$ reported that aromatic solvents do participate in the thermolysis of diarylmetallocenes. In order to prevent the ring exchange between the $\sigma$ bonded phenyl ligands bound to the metal and an aromatic solvent, these reactions were carried out in cyclohexane.

\section{(a) Synthesis of $\left[\left(\mathrm{C}_{5} \mathrm{H}_{4}\right) \mathrm{SiMe}_{2}(\mathrm{~N}-\mathrm{t}-\mathrm{Bu})\right] \mathrm{Ti}\left[\left(\mathrm{C}_{6} \mathrm{H}_{4}\right) \mathrm{C}(\mathrm{Ph})=\mathrm{C}(\mathrm{Ph})\right]$}

The coupling reaction involving $\left[\left(\mathrm{C}_{5} \mathrm{H}_{4}\right) \mathrm{SiMe}_{2}(\mathrm{~N}-\mathrm{t}-\mathrm{Bu})\right] \mathrm{Ti}\left(\mathrm{C}_{6} \mathrm{H}_{5}\right)_{2}$ and diphenylacetylene was heated in cyclohexane at $80^{\circ} \mathrm{C}$ (Figure 5). The reaction proceeded smoothly with the formation of one primary product. The resulting deep red product residue was washed with minimal amounts of hexamethyldisiloxane. Reddish-orange crystals of the product, $\left[\left(\mathrm{C}_{5} \mathrm{H}_{4}\right) \mathrm{SiMe}_{2}(\mathrm{~N}-\mathrm{t}-\mathrm{Bu})\right] \mathrm{Ti}\left[\left(\mathrm{C}_{6} \mathrm{H}_{4}\right) \mathrm{C}(\mathrm{Ph})=\mathrm{C}(\mathrm{Ph})\right]$ were isolated after recrystallization from a concentrated pentane solution. These crystals were found to be suitable for an X-ray structural analysis (vide infra).

The reaction conditions differ somewhat from those used for the coupling reaction of diphenylacetylene an $\left(\mathrm{C}_{5} \mathrm{H}_{5}\right)_{2} \mathrm{Ti}_{(}\left(\mathrm{C}_{6} \mathrm{H}_{5}\right)_{2} .{ }^{9}$ Here, cyclohexane rather than benzene was used as the solvent with the reaction time being extended to $24 \mathrm{~h}$ to ensure completion.

The coupling reaction is believed to proceed initially with intramolecular elimination of benzene to produce a benzyne intermediate. 


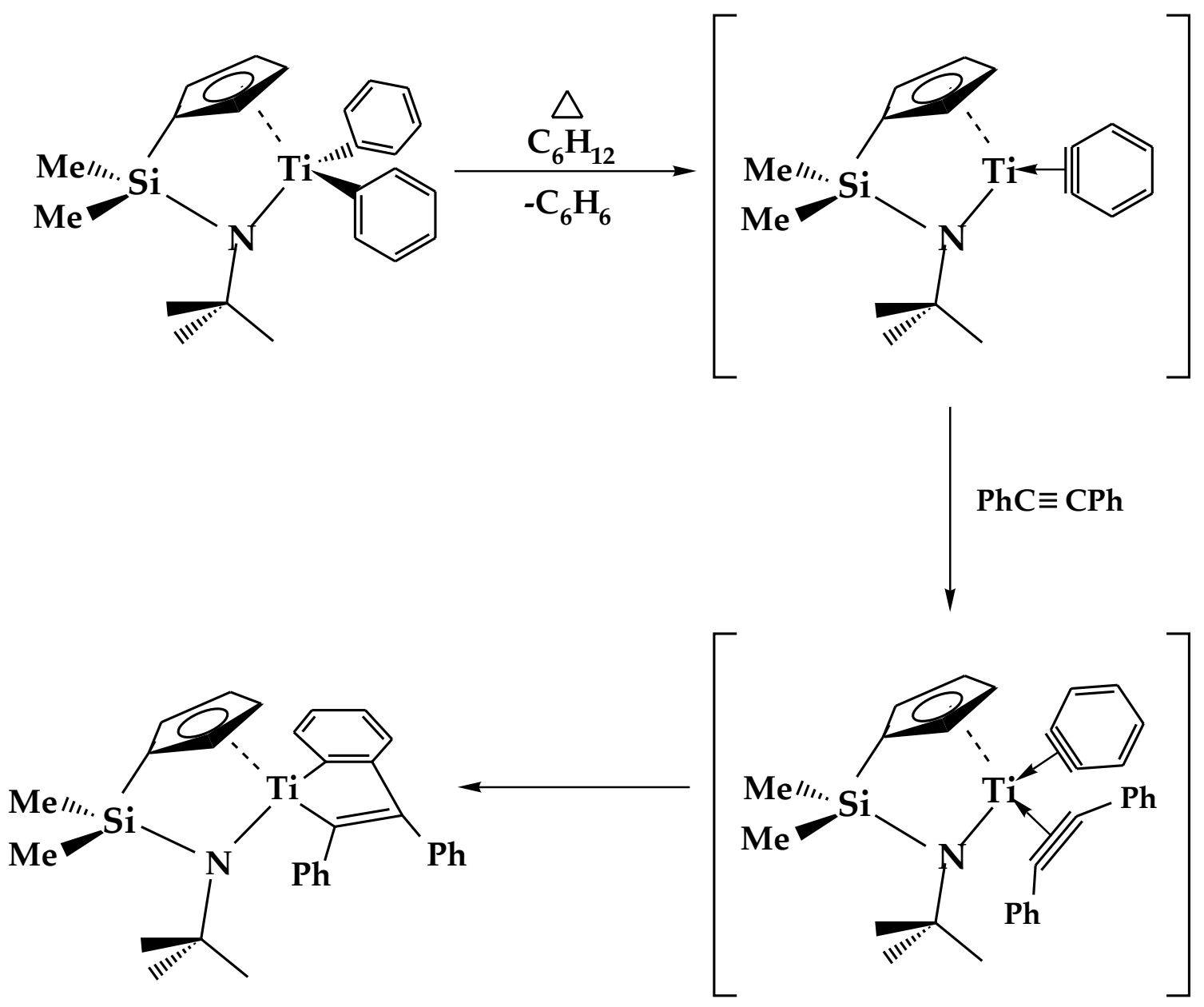

Figure 5. Coupling reaction of $\left[\left(\mathrm{C}_{5} \mathrm{H}_{4}\right) \mathrm{SiMe}_{2}(\mathrm{~N}-\mathrm{t}-\mathrm{Bu})\right] \mathrm{Ti}\left(\mathrm{C}_{6} \mathrm{H}_{5}\right)_{2}$ with diphenylacetylene.

This electrophilic species is presumably stabilized by complexation of diphenylacetylene. Following complexation, intramolecular C-C bond 
coupling proceeds with the formation of the titanacyclopentadiene product (Figure 5).

The identity of $\left[\left(\mathrm{C}_{5} \mathrm{H}_{4}\right) \mathrm{SiMe}_{2}(\mathrm{~N}-\mathrm{t}-\mathrm{Bu})\right] \mathrm{Ti}\left[\left(\mathrm{C}_{6} \mathrm{H}_{4}\right) \mathrm{C}(\mathrm{Ph})=\mathrm{C}(\mathrm{Ph})\right] \quad$ was verified by solution ${ }^{1} \mathrm{H}$ and ${ }^{13} \mathrm{C}$ NMR measurements along with $2 \mathrm{D}$ HETCOR and COSY NMR measurements in $\mathrm{CDCl}_{3}$. The NMR data indicate that the molecule lacks mirror symmetry in solution. Due to the presence of many overlapping resonances in the aromatic regions of the ${ }^{13} \mathrm{C}$ and ${ }^{1} \mathrm{H}$ NMR spectra, 2D NMR techniques were employed in order to identify and assign the individual resonances. The ${ }^{1} \mathrm{H}$ NMR spectrum contains peaks at $\delta 7.18$, $7.13,7.05,6.83,6.75$, and 6.70 for the six inequivalent protons on the two independent phenyl substituents of the titanacyclopentadiene ring. The four benzyne proton resonances are found as doublets at $\delta 7.00,6.96,6.83$, and 6.50, with the four chemically inequivalent protons of the cyclopentadienyl group appearing as pseudo triplets at $\delta 7.47,7.03,6.20$, and 5.55 . There is a singlet at $\delta$ 1.58 representing the nine methyl protons of the t-butyl group and two singlets at $\delta 0.59$ and $\delta 0.49$ for the two inequivalent methyl groups of the $\mathrm{SiMe}_{2}$ bridge.

The ${ }^{1} \mathrm{H}$ NMR resonances for the cyclopentadienyl and benzyne functional groups were subsequently verified by the 2D COSY NMR spectrum, which contains an off-diagonal peak for each pair of coupled protons (Figure 6). The benzyne proton resonance at $\delta 6.50$ has three offdiagonal peaks at $\delta 6.83,6.96$, and 7.00 due to coupling with the three other benzyne proton signals. The remaining three proton chemical shifts for the benzyne functionality all exhibit three off-diagonal peaks consistent with the assignment of these resonances to the benzyne functionality.

In the case of the cyclopentadienyl group, the four distal and proximal protons are diastereotopic and therefore exhibit four distinct resonances. The 
peak at $\delta 7.47$ is coupled to two other protons at $\delta 7.03$ and $\delta 6.20$. The resonance at $\delta 7.03$ is coupled to the protons at $\delta 7.47$ and $\delta 5.55$. The peak centered at $\delta 6.20$ is coupled to proton resonances at $\delta 7.47$ and $\delta 5.55$. The peak at $\delta 5.55$ indicates coupling to the two signals centered at $\delta 7.03$ and $\delta 6.20$.

The corresponding ${ }^{13} \mathrm{C}\left\{{ }^{1} \mathrm{H}\right\}$ NMR spectrum exhibits the expected number of twenty five carbon resonances. Due to the large number of overlapping resonances, a 2D HETCOR NMR spectrum was recorded to assist in the assignment of the carbon resonances (Figure 7). The 2D HETCOR NMR spectrum made it possible to assign the carbon signals associated with specific fragments within the molecule by analyzing the ${ }^{13} \mathrm{C}$ and ${ }^{1} \mathrm{H}$ chemical shifts associated with the observed peaks. Each peak in the HETCOR spectrum corresponds to a carbon bearing one or more hydrogen atoms with its position correlating the respective chemical shifts for the corresponding carbon and proton signals. The quaternary carbons can be distinguished from carbon atoms bearing protons by the fact that these carbons do not exhibit a peak in the HETCOR spectrum The two methyl carbons of the $\mathrm{SiMe}_{2}$ bridge appear at $\delta 0.75$ and $\delta 1.01$. The three methyl carbons and the quaternary carbon of the amido functionality appear at $\delta 34.0$ and $\delta 60.1$, respectively. The cyclopentadienyl group exhibits five resonances with the signal at $\delta 107.9$ representing the bridgehead carbon and the four resonances at $\delta 121.8,122.05$, 126.0, and 126.4 corresponding to the four remaining carbon atoms of the cyclopentadienyl ring. There are six carbon resonances for the benzyne functionality, where the signals at $\delta 124.7,126.5,127.4$, and 128.2 correspond to the four carbons bearing hydrogens and the two peaks at $\delta 145.8$ and $\delta 193.7$ represent two quaternary carbons within the five-membered 
Figure 6. 2D COSY NMR spectrum for $\left[\left(\mathrm{C}_{5} \mathrm{H}_{4}\right) \mathrm{SiMe}_{2}(\mathrm{~N}-\mathrm{t}-\mathrm{Bu})\right] \mathrm{Ti}\left[\left(\mathrm{C}_{6} \mathrm{H}_{4}\right) \mathrm{C}(\mathrm{Ph})=\mathrm{C}(\mathrm{Ph})\right]$. 


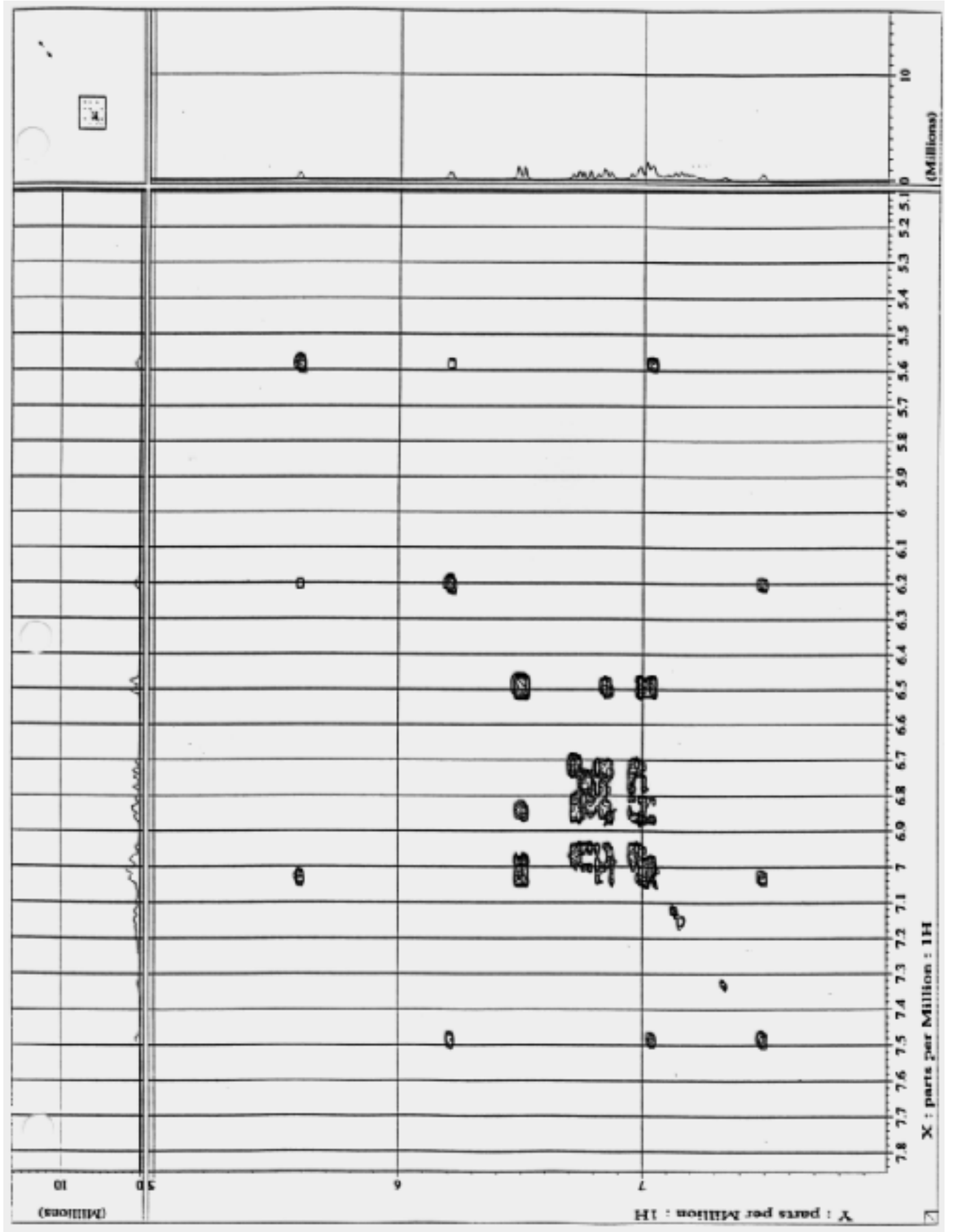


Figure 7. 2D HETCOR NMR spectrum measured for $\left[\left(\mathrm{C}_{5} \mathrm{H}_{4}\right) \mathrm{SiMe}_{2}(\mathrm{~N}-\mathrm{t}-\mathrm{Bu})\right] \mathrm{Ti}\left[\left(\mathrm{C}_{6} \mathrm{H}_{4}\right) \mathrm{C}(\mathrm{Ph})=\mathrm{C}(\mathrm{Ph})\right]$. 


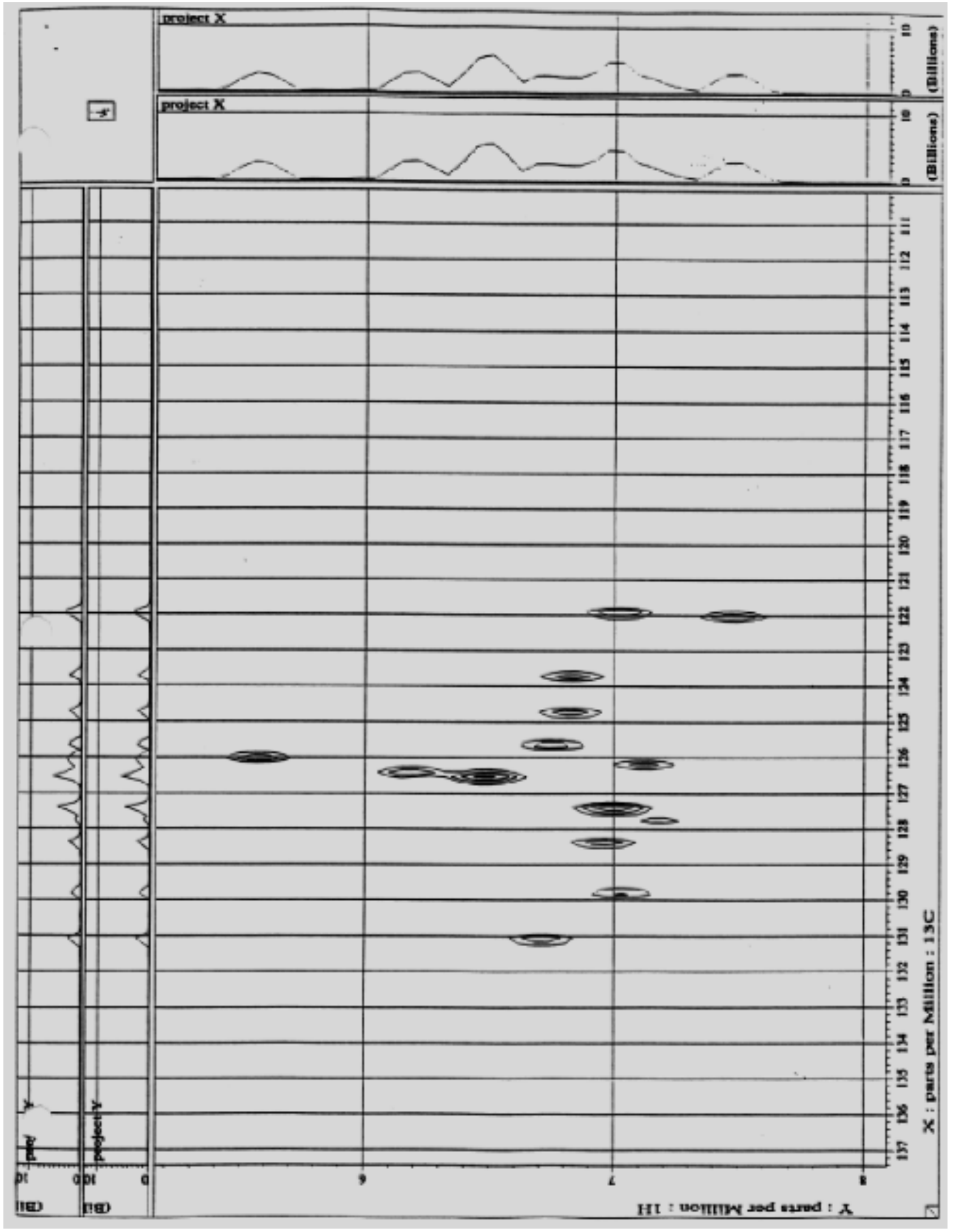


titanacyclopentadiene ring. The two phenyl substituents of the metallacycle exhibit the expected eight carbon resonances, with the signals at $\delta 123.7,125.7$, $126.2,127.8,129.8$, and 131.05 representing the ortho-, meta-, and para-carbons of the phenyl rings and the two resonances at $\delta 138.9$ and $\delta 144.4$ assigned to the two ipso-quaternary carbons. The two resonances at $\delta 147.9$ and $\delta 206.1$ corespond to the two remaining carbons of the five membered titanacyclic ring.

\section{(b) Synthesis of $\left[\left(\mathrm{C}_{5} \mathrm{Me}_{4}\right) \mathrm{SiMe}_{2}(\mathrm{~N}-\mathrm{t}-\mathrm{Bu})\right] \mathrm{Zr}\left[\left(\mathrm{C}_{6} \mathrm{H}_{4}\right) \mathrm{C}(\mathrm{Ph})=\mathrm{C}(\mathrm{Ph})\right]$}

The coupling reaction between $\left[\left(\mathrm{C}_{5} \mathrm{Me}_{4}\right) \mathrm{SiMe}_{2}(\mathrm{~N}-\mathrm{t}-\mathrm{Bu})\right] \mathrm{Zr}\left(\mathrm{C}_{6} \mathrm{H}_{5}\right)_{2}$ and diphenylacetylene was carried out in cyclohexane, (Figure 8). The reaction mixture was heated to $60^{\circ} \mathrm{C}$ for two days resulting in the formation of a crude product mixture from which the desired product was isolated after numerous washings with hexamethyldisiloxane. The product was isolated as a dry offwhite solid. This coupling reaction presumably proceeds in a similar manner to that proposed for the formation of $\left[\left(\mathrm{C}_{5} \mathrm{H}_{4}\right) \mathrm{SiMe}_{2}(\mathrm{~N}-\mathrm{t}-\right.$ $\mathrm{Bu})] \operatorname{Ti}\left[\left(\mathrm{C}_{6} \mathrm{H}_{4}\right) \mathrm{C}(\mathrm{Ph})=\mathrm{C}(\mathrm{Ph})\right]$ (Figure 8).

The identity of $\left[\left(\mathrm{C}_{5} \mathrm{Me}_{4}\right) \mathrm{SiMe}_{2}(\mathrm{~N}-\mathrm{t}-\mathrm{Bu})\right] \mathrm{Zr}\left[\left(\mathrm{C}_{6} \mathrm{H}_{4}\right) \mathrm{C}(\mathrm{Ph})=\mathrm{C}(\mathrm{Ph})\right]$ was verified by solution ${ }^{1} \mathrm{H}$ and ${ }^{13} \mathrm{C}$ NMR measurements along with $2 \mathrm{D}$ HETCOR and COSY NMR measurements in $\mathrm{CDCl}_{3}$. As expected, the solution $\mathrm{NMR}$ data indicate that the molecule lacks mirror symmetry. With the presence of many overlapping resonances in the aromatic regions of both ${ }^{1} \mathrm{H}$ and ${ }^{13} \mathrm{C}$ NMR spectra, 2D NMR techniques were employed to aid in the assignment of individual resonances. The ${ }^{1} \mathrm{H}$ NMR spectrum contains peaks at $\delta 7.22,7.18$, 7.12, 6.98, 6.94, and 6.86 for the six inequivalent protons of the two independent phenyl substituents of the zirconacyclopentadiene ring. The 
chemical shifts of the four proton resonances of the benzyne functionality at $\delta$ $7.01,6.96,6.79$, and 6.55 are similar to those for the benzyne proton resonances in $\left[\left(\mathrm{C}_{5} \mathrm{H}_{4}\right) \mathrm{SiMe}_{2}(\mathrm{~N}-\mathrm{t}-\mathrm{Bu})\right] \mathrm{Ti}\left[\left(\mathrm{C}_{6} \mathrm{H}_{4}\right) \mathrm{C}(\mathrm{Ph})=\mathrm{C}(\mathrm{Ph})\right]$. This spectrum further contains four singlets at $\delta 2.22,1.97,1.95$, and 1.52 for the four sets of methyl protons on the tetramethylcyclopentadienyl ring and a singlet at $\delta 1.54$ representing the nine methyl protons of the appended t-butyl amido functionality. There are two singlets at $\delta 0.61$ and $\delta 0.53$ for the two inequivalent methyl groups of the $\mathrm{SiMe}_{2}$ bridge.

The ${ }^{1} \mathrm{H}$ NMR resonances for the benzyne functionality were subsequently verified by the 2D COSY NMR spectrum. Each off-diagonal peak indicates coupling between pairs of protons (Figure 9). The benzyne proton resonance at $\delta 6.55$ has three off-diagonal peaks at $\delta 6.79,6.96$, and 7.01 due to coupling with the three other benzyne proton signals. These three other protons of the benzyne functionality also exhibit three off-diagonal peaks consistent with their assignment to the benzyne functionality.

The corresponding ${ }^{13} \mathrm{C}\left\{{ }^{1} \mathrm{H}\right\}$ NMR spectrum exhibits the expected number of twenty nine carbon resonances. With the large number of overlapping resonances, a 2D HETCOR NMR measurement was taken to aid in the assignment of the carbon resonances (Figure 10). The 2D HETCOR NMR correlates chemical shifts between ${ }^{13} \mathrm{C}$ and ${ }^{1} \mathrm{H}$ nuclei that are directly bonded to one another. Quaternary carbon resonances can be assigned from the fact that no peaks are observed for carbons lacking protons. The two methyl carbons of the $\mathrm{SiMe}_{2}$ bridge appear at $\delta 6.36$ and $\delta 6.51$. The three methyl carbons and the quaternary carbon of the t-butyl amido functionality appear at $\delta 33.7$ and $\delta 56.2$, respectively. The methyl carbons of the tetramethylcyclopentadienyl ring display four resonances at $\delta 13.9,13.3,12.2$, 

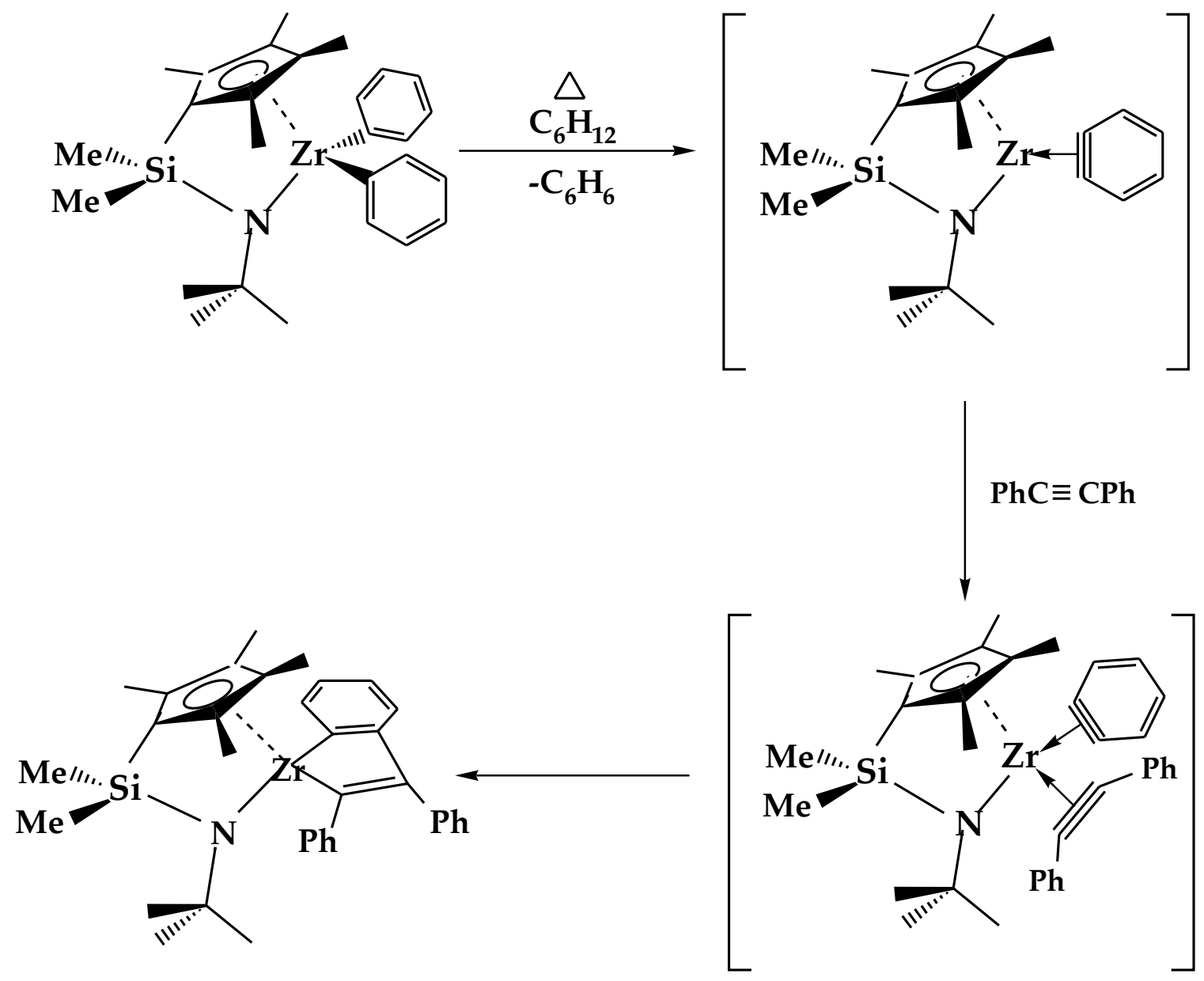

Figure 8. Coupling reaction of $\left[\left(\mathrm{C}_{5} \mathrm{Me}_{4}\right) \mathrm{SiMe}_{2}(\mathrm{~N}-\mathrm{t}-\mathrm{Bu})\right] \mathrm{Zr}\left(\mathrm{C}_{6} \mathrm{H}_{5}\right)_{2}$ with diphenylacetylene. 
Figure 9. 2D COSY NMR spectrum for $\left[\left(\mathrm{C}_{5} \mathrm{Me}_{4}\right) \mathrm{SiMe}_{2}(\mathrm{~N}-\mathrm{t}-\mathrm{Bu})\right] \mathrm{Zr}\left[\left(\mathrm{C}_{6} \mathrm{H}_{4}\right) \mathrm{C}(\mathrm{Ph})=\mathrm{C}(\mathrm{Ph})\right]$. 


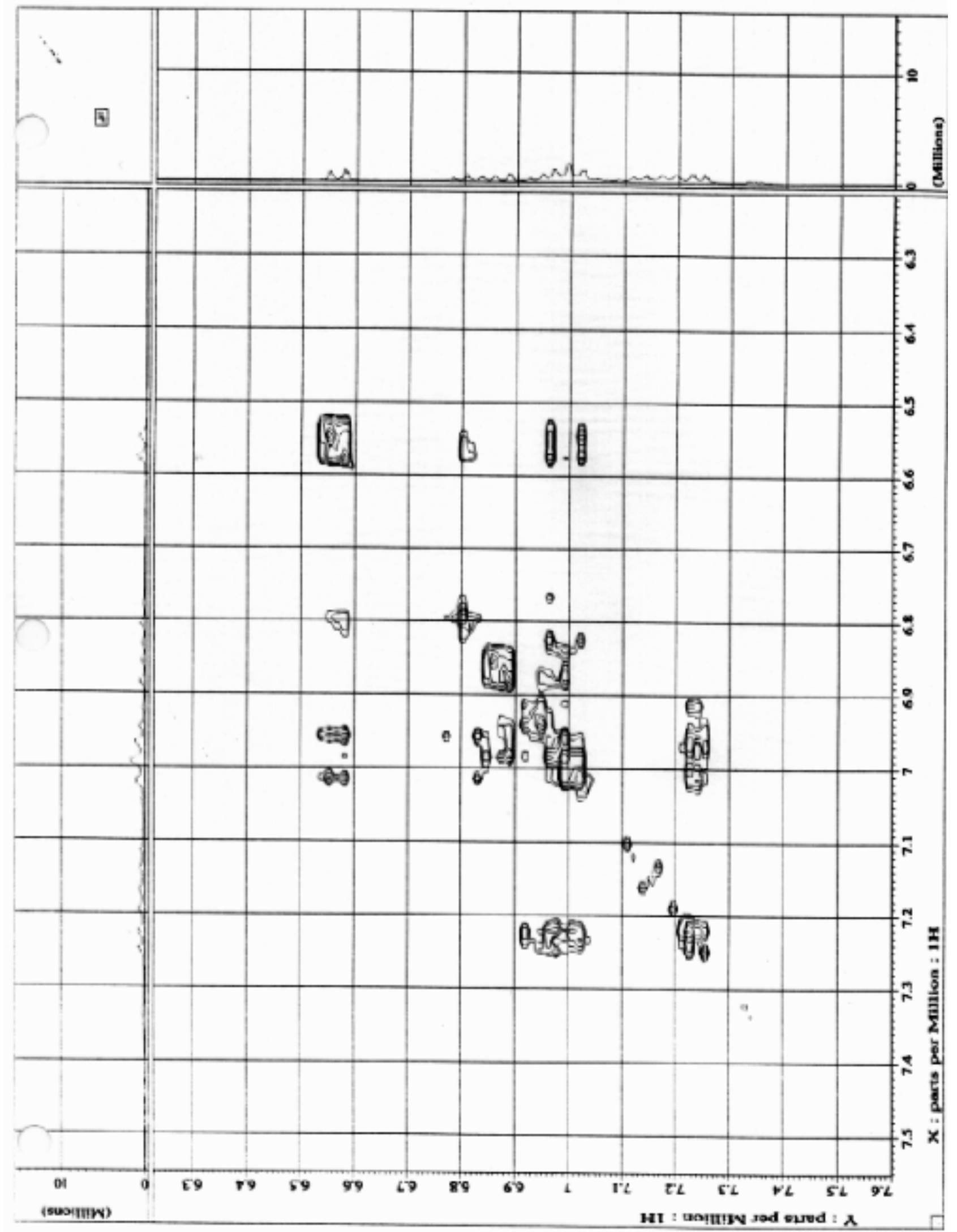


and 11.4. There is a signal at $\delta 97.4$ representing the bridgehead carbon of the cyclopentadienyl ring and four resonances at $\delta 127.9,128.6,132.7$, and 132.8 for the four remaining ring carbons. There are six signals for the benzyne functionality, with the peaks at $\delta 126.9,123.2,127.2$, and 128.1 corresponding to the four carbon atoms with hydrogens leaving the two peaks at $\delta 146.3$ and $\delta 186.7$ assigned to the two quaternary carbons within the five-membered zirconacyclopentadiene ring The two independent phenyl substituents exhibit eight carbon resonances. The peaks at $\delta 124.8,125.7,127.6$, $127.8,130.1$, and 133.1 represent the ortho-, meta-, and para-carbons and the two resonances at $\delta 140.9$ and $\delta 144.7$ are due to the two ipso-quaternary carbons. The two signals at $\delta 150.5$ and $\delta 197.2$ correspond to the two remaining carbons atoms of the five-membered zirconacyclic ring.

\section{Description of the Molecular Structure of $\left[\left(\mathrm{C}_{5} \mathrm{H}_{4}\right) \mathrm{SiMe}_{2}(\mathrm{~N}-\mathrm{t}-\right.$ $\mathrm{Bu})] \mathrm{Ti}\left[\left(\mathrm{C}_{6} \mathrm{H}_{4}\right) \mathrm{C}(\mathrm{Ph})=\mathrm{C}(\mathrm{Ph})\right]$.}

The molecular structure of $\left[\left(\mathrm{C}_{5} \mathrm{H}_{4}\right) \mathrm{SiMe}_{2}(\mathrm{~N}-\mathrm{t}-\right.$ $\mathrm{Bu})] \operatorname{Ti}\left[\left(\mathrm{C}_{6} \mathrm{H}_{4}\right) \mathrm{C}(\mathrm{Ph})=\mathrm{C}(\mathrm{Ph})\right]$ was confirmed by an X-ray crystallographic analysis. This organotitanium compound crystallizes in a C-centered monoclinic lattice with 8 symmetry-related molecules within the unit cell. A perspective view of its molecular structure is shown in Figure 11 with the atom numbering scheme. Pertinent bond distances and angles are provided in Table 4. The molecular structure is well-behaved with no indications of a structural disorder or excessive thermal motion.

The most prominent feature in this structure is the titanacyclopentadiene ring constructed from the direct C-C coupling of a coordinated benzyne fragment with diphenylacetylene. This titanacyclic ring 
Figure 10. 2D HETCOR NMR spectrum measured for $\left[\left(\mathrm{C}_{5} \mathrm{Me}_{4}\right) \mathrm{SiMe}_{2}(\mathrm{~N}-\mathrm{t}-\mathrm{Bu})\right] \mathrm{Zr}\left[\left(\mathrm{C}_{6} \mathrm{H}_{4}\right) \mathrm{C}(\mathrm{Ph})=\mathrm{C}(\mathrm{Ph})\right]$. 


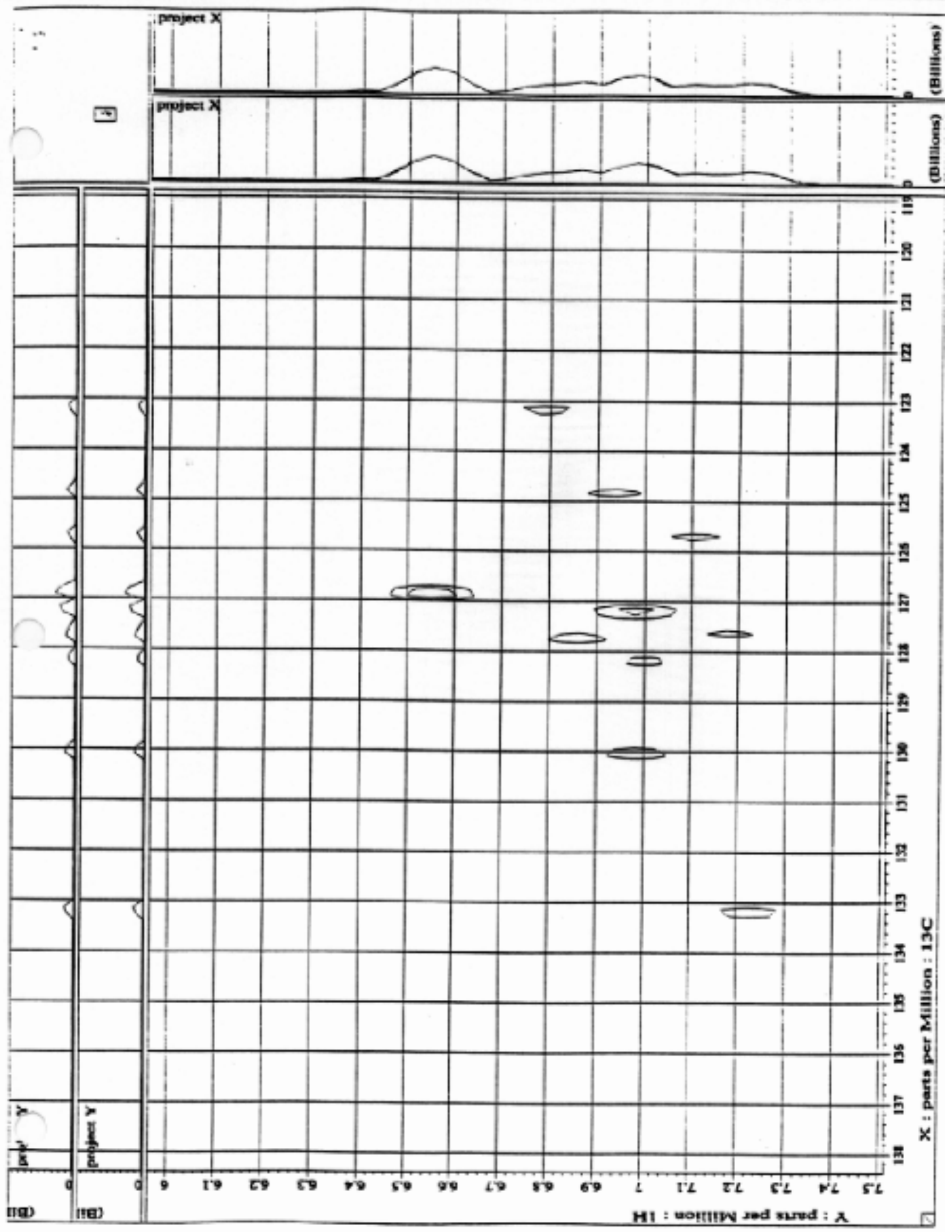


is essentially planar with the mean deviation for the $\mathrm{Ti}$ and four carbon atoms being $0.035 \AA$. The three independent C-C distances of 1.404(8), 1.511(8) and $1.355(8) \AA$ are consistent with alternating localized $\mathrm{C}=\mathrm{C}$ double bonds around the ring with the longer $\mathrm{C}=\mathrm{C}$ bond being associated with the benzyne fragment. The five-membered titanacyclopentadiene ring and the six membered ring of the $\mathrm{C}_{6} \mathrm{H}_{4}$ fragment are essentially coplanar, with the acute dihedral angle between their respective planes being only $3.5^{\circ}$. To minimize interring repulsions, the two phenyl substituents containing carbon atoms $C(20)-C(25)$ and $C(26)-C(31)$ are rotated by $76.8^{\circ}$ and $41.3^{\circ}$, respectively, out of the plane of the titanacyclopentadiene ring.

The asymmetric pseudo-tetrahedral coordination sphere consists of the $\pi$-bonded cyclopentadienyl ring and its appended amido functionality and two chemically inequivalent Ti-C bonds of 2.081(7) and 2.103(7) $\AA$. These two distances are considerably shorter than the two independent Ti-C bonds of 2.172(5) and 2.141(5) $\AA$ reported by Atwood and co-workers ${ }^{39}$ for the related planar titanacyclopentadiene ring of $\mathrm{Cp}_{2} \mathrm{Ti}_{2}\left(\mathrm{C}_{4}(\mathrm{Ph})_{4}\right)$, which was prepared by the photolysis of $\mathrm{Cp}_{2} \mathrm{TiMe}_{2}$ in the presence of diphenylacetylene. This observed difference in these two pairs of Ti-C bond distances is most likely a consequence of the increased electrophilicity associated with the electron deficient $\mathrm{d}^{0} \mathrm{Ti}(\mathrm{IV})$ center arising from the presence of the bifunctional ansamonocyclopentadienylamido ligand in $\left[\left(\mathrm{C}_{5} \mathrm{H}_{4}\right) \mathrm{SiMe}_{2}(\mathrm{~N}-\mathrm{t}-\right.$ $\mathrm{Bu})] \operatorname{Ti}\left[\left(\mathrm{C}_{6} \mathrm{H}_{4}\right) \mathrm{C}(\mathrm{Ph})=\mathrm{C}(\mathrm{Ph})\right]$, thus leading to a substantial shortening of both of its Ti-C bonds. The $\mathrm{C}(12)-\mathrm{Ti}-\mathrm{C}(15)$ bond angle of $85.1(3)^{\circ}$ within the five membered titanacyclopentadiene ring of $\left[\left(\mathrm{C}_{5} \mathrm{H}_{4}\right) \mathrm{SiMe}_{2}(\mathrm{~N}-\mathrm{t}-\right.$ $\mathrm{Bu})] \operatorname{Ti}\left[\left(\mathrm{C}_{6} \mathrm{H}_{4}\right) \mathrm{C}(\mathrm{Ph})=\mathrm{C}(\mathrm{Ph})\right]$ is $c a .5^{\circ}$ larger than the corresponding $\mathrm{C}-\mathrm{Ti}-\mathrm{C}$ angle in $\mathrm{Cp}_{2} \mathrm{Ti}\left(\mathrm{C}_{4}(\mathrm{Ph})_{4}\right)$. This increase is accompanied by a ca. $3^{\circ}$ decrease in the Ti$\mathrm{C}_{\alpha}-\mathrm{C}_{\beta}$ bond angles. 
The presence of the $\mathrm{SiMe}_{2}$ linkage between the cyclopentadienyl and amido functionalities of $\left[\left(\mathrm{C}_{5} \mathrm{H}_{4}\right) \mathrm{SiMe}_{2}(\mathrm{~N}-\mathrm{t}-\mathrm{Bu})\right] \mathrm{Ti}\left[\left(\mathrm{C}_{6} \mathrm{H}_{4}\right) \mathrm{C}(\mathrm{Ph})=\mathrm{C}(\mathrm{Ph})\right]$ produces a $\mathrm{Cp}(\mathrm{c})-\mathrm{Ti}-\mathrm{N}$ angle of $108.4^{\circ}$, which is only modestly larger than its corresponding value of $107.0^{\circ}$ in $\left[\left(\mathrm{C}_{5} \mathrm{H}_{4}\right) \mathrm{SiMe}_{2}(\mathrm{~N}-\mathrm{t}-\mathrm{Bu})\right] \mathrm{TiCl}_{2}$. The similarity of the respective Ti-N(amido) (1.915(5) and 1.901(3) $\AA$ ) and Ti-Cp(c) (2.025 and $2.019 \AA$ ) for these two complexes indicates that these distances are relatively insensitive to the presence of the titanacyclopentadiene ring. 
Figure 11. Perspective view of the molecular structure of $\left[\left(\mathrm{C}_{5} \mathrm{H}_{4}\right) \mathrm{SiMe}_{2}(\mathrm{~N}-\mathrm{t}-\mathrm{Bu})\right] \operatorname{Ti}\left[\left(\mathrm{C}_{6} \mathrm{H}_{4}\right) \mathrm{C}(\mathrm{Ph})=\mathrm{C}(\mathrm{Ph})\right]$ with the non-hydrogen atom labeling scheme. 


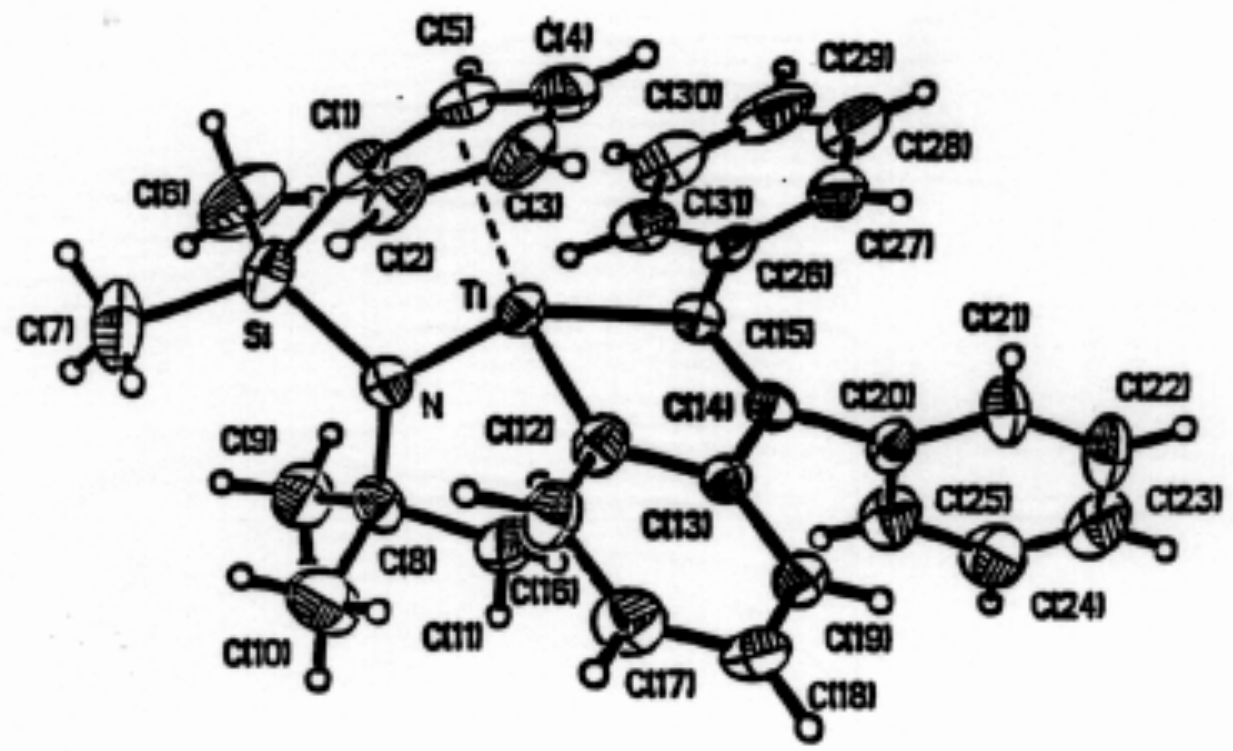




\section{Concluding Remarks}

The metathetical reaction of $\left[\left(\mathrm{C}_{5} \mathrm{R}_{4}\right) \mathrm{SiMe}_{2}(\mathrm{~N}-\mathrm{t}-\mathrm{Bu})\right] \mathrm{MCl}_{2}$ with two equivalents of an appropriate phenylating reagent results in the formation of $\left[\left(\mathrm{C}_{5} \mathrm{R}_{4}\right) \mathrm{SiMe}_{2}(\mathrm{~N}-\mathrm{t}-\mathrm{Bu})\right] \mathrm{M}\left(\mathrm{C}_{6} \mathrm{H}_{5}\right)_{2} \quad(\mathrm{R}=\mathrm{H}, \mathrm{Me} ; \mathrm{M}=\mathrm{Ti}, \mathrm{Zr})$, which have been characterized by both ${ }^{1} \mathrm{H}$ and ${ }^{13} \mathrm{C}$ NMR measurements. The utilization of a specific phenyl reagent is not general for the preparation of these diphenyl complexes, but is dependent on the choice of the dichloride precursor.

The stoichiometric reaction of $\left[\left(\mathrm{C}_{5} \mathrm{H}_{4}\right) \mathrm{SiMe}_{2}(\mathrm{~N}-\mathrm{t}-\mathrm{Bu})\right] \mathrm{TiCl}_{2}$ with two equivalents of $\mathrm{PhMgBr}$ produced $\left[\left(\mathrm{C}_{5} \mathrm{H}_{4}\right) \mathrm{SiMe}_{2}(\mathrm{~N}-\mathrm{t}-\mathrm{Bu})\right] \mathrm{Ti}\left(\mathrm{C}_{6} \mathrm{H}_{5}\right)_{2}$ in reasonable yield. The reaction of $\left[\left(\mathrm{C}_{5} \mathrm{Me}_{4}\right) \mathrm{SiMe}_{2}(\mathrm{~N}-\mathrm{t}-\mathrm{Bu})\right] \mathrm{ZrCl}_{2}$ with two equivalents of $\mathrm{PhLi}$ proceeded cleanly with the formation of $\left[\left(\mathrm{C}_{5} \mathrm{Me}_{4}\right) \mathrm{SiMe}_{2}(\mathrm{~N}-\mathrm{t}-\mathrm{Bu})\right] \mathrm{Zr}\left(\mathrm{C}_{6} \mathrm{H}_{5}\right)_{2}$ in a relatively good yield. Upon treating $\left[\left(\mathrm{C}_{5} \mathrm{H}_{4}\right) \mathrm{SiMe}_{2}(\mathrm{~N}-\mathrm{t}-\mathrm{Bu})\right] \mathrm{ZrCl}_{2}$ with two equivalents of $\mathrm{PhMgCl}$, the desired product, $\left[\left(\mathrm{C}_{5} \mathrm{H}_{4}\right) \mathrm{SiMe}_{2}(\mathrm{~N}-\mathrm{t}-\mathrm{Bu})\right] \mathrm{Zr}\left(\mathrm{C}_{6} \mathrm{H}_{5}\right)_{2}$ was obtained. The isolation of $\left[\left(\mathrm{C}_{5} \mathrm{H}_{4}\right) \mathrm{SiMe}_{2}(\mathrm{~N}-\mathrm{t}-\mathrm{Bu})\right] \mathrm{Zr}\left(\mathrm{C}_{6} \mathrm{H}_{5}\right)_{2}$, was hindered by its tendency to decompose within a few hours upon standing at ambient temperature. This color change was accompanied by deterioration of the NMR spectral features for $\left[\left(\mathrm{C}_{5} \mathrm{H}_{4}\right) \mathrm{SiMe}_{2}(\mathrm{~N}-\mathrm{t}-\mathrm{Bu})\right] \mathrm{Zr}\left(\mathrm{C}_{6} \mathrm{H}_{5}\right)_{2}$.

Two of the diphenyl precursors, $\left[\left(\mathrm{C}_{5} \mathrm{H}_{4}\right) \mathrm{SiMe}_{2}(\mathrm{~N}-\mathrm{t}-\mathrm{Bu})\right] \mathrm{Ti}\left(\mathrm{C}_{6} \mathrm{H}_{5}\right)_{2}$ and $\left[\left(\mathrm{C}_{5} \mathrm{Me}_{4}\right) \mathrm{SiMe}_{2}(\mathrm{~N}-\mathrm{t}-\mathrm{Bu})\right] \mathrm{Zr}\left(\mathrm{C}_{6} \mathrm{H}_{5}\right)_{2}$, were each separately reacted with one equivalent of diphenylacetylene in an effort to trap the benzyne intermediate and to isolate the resultant five membered metallacyclic product. The coupling reaction involving $\left[\left(\mathrm{C}_{5} \mathrm{H}_{4}\right) \mathrm{SiMe}_{2}(\mathrm{~N}-\mathrm{t}-\mathrm{Bu})\right] \mathrm{Ti}\left(\mathrm{C}_{6} \mathrm{H}_{5}\right)_{2}$ and diphenylacetylene proceeded smoothly in cyclohexane at $80^{\circ} \mathrm{C}$ with the formation of one primary product, $\left[\left(\mathrm{C}_{5} \mathrm{H}_{4}\right) \mathrm{SiMe}_{2}(\mathrm{~N}-\mathrm{t}-\right.$ $\mathrm{Bu})] \operatorname{Ti}\left[\left(\mathrm{C}_{6} \mathrm{H}_{4}\right) \mathrm{C}(\mathrm{Ph})=\mathrm{C}(\mathrm{Ph})\right]$. The reaction of $\left[\left(\mathrm{C}_{5} \mathrm{Me}_{4}\right) \mathrm{SiMe}_{2}(\mathrm{~N}-\mathrm{t}-\mathrm{Bu})\right] \mathrm{Zr}\left(\mathrm{C}_{6} \mathrm{H}_{5}\right)_{2}$ with one equivalent of diphenylacetylene led to a product mixture from 
which the desired product $\left[\left(\mathrm{C}_{5} \mathrm{Me}_{4}\right) \mathrm{SiMe}_{2}(\mathrm{~N}-\mathrm{t}-\mathrm{Bu})\right] \mathrm{Zr}\left[\left(\mathrm{C}_{6} \mathrm{H}_{4}\right) \mathrm{C}(\mathrm{Ph})=\mathrm{C}(\mathrm{Ph})\right]$ was isolated. Each of these two products was characterized by both ${ }^{1} \mathrm{H}$ and ${ }^{13} \mathrm{C}$ NMR along with COSY and HETCOR 2D NMR measurements.

The molecular structure of $\left[\left(\mathrm{C}_{5} \mathrm{H}_{4}\right) \mathrm{SiMe}_{2}(\mathrm{~N}-\mathrm{t}-\right.$ $\mathrm{Bu})] \operatorname{Ti}\left[\left(\mathrm{C}_{6} \mathrm{H}_{4}\right) \mathrm{C}(\mathrm{Ph})=\mathrm{C}(\mathrm{Ph})\right]$ was confirmed by $\mathrm{X}$-ray structural analysis. This compound exhibits an asymmetric pseudo-tetrahedral coordination sphere consisting of a bifunctional ansa-monocyclopentadienylamido chelate ligand and a $\pi$-bonded cyclopentadienyl ring. The two inequivalent Ti-C bond distances are considerably shorter than the two independent Ti-C bonds of $\mathrm{Cp}_{2} \mathrm{Ti}\left(\mathrm{C}_{4}(\mathrm{Ph})_{4}\right)$ reported in the literature. The observed difference in these two pairs of Ti-C bond distances is most likely a consequence of the increased electrophilicity associated with the electron deficient $\mathrm{d}^{0} \mathrm{Ti}(\mathrm{IV})$ center arising from the presence of the bifunctional ansa-monocyclopentadienylamido ligand, leading to a substantial shortening of the two Ti-C bonds. 


\section{References}

1. (a) Criegee, R.; Schräder, G. Justus Liebigs Ann. Chem. 1959, 623, 1.

(b) Hübel, W.; Braye, E.H. J. Inorg. Nucl. Chem. 1959, 10, 250.

2. Emerson, G.F.; Ehrlich, K.; Giering, W.P.; Lauterbur P.C. J. Am. Chem. Soc. 1966, 88, 3172.

3. Cardin, D.J.; Cetinkaya, B.; Doyle, M.J.; Lappert, M.F. Chem. Soc. Rev. 1973, 2, 99 .

4. Robertson, G.B.; Whimp, P.O. J. Organomet. Chem. 1971, 32, C69.

5. (a) McLain, S.J.; Schrock, R.R.; Sharp, P.R.; Churchill, M.R.; Youngs, W.J.; J. Am. Chem Soc., 1970, 101, 263.

(b) Churchill, M.R.; Youngs, W.J. Inorg. Chem. 1979, 18, 1697.

${ }^{6}$. Hoffmann, R.W. Dehydrobenzene and Cycloalkynes; Academic Press: New York, NY, 1967.

7. Chapman, O.L.; Mattes,K.; McIntosh,J.; Pacansky, J.; Calder, G.V.; Orr, G. J. Am. Chem. Soc. 1973, 95, 6134.

8. Lang, J.W.; Berry, R.S. J. Am. Chem. Soc. 1976, 98, 660.

9. Masai, H.; Sonogashira, K.; Hagihara, N. Bull. Chem. Soc. Jpn. 1968, 310, 311.

${ }^{10}$. Kolomnikov, I.S.; Lobeeva, T. S; Gorbachevskaya, V.V.; Aleksandrov, G.G; Struckhov, Yu. T.; Vol'pin, M.E. J. Chem. Soc. Chem. Comm. 1971, 972.

11. Boekel, C.P.; Teuben, J.H.; de Liefde Meijer, H.J. J. Organomet. Chem. 1974, $81,371$.

12. Erker, G. J. Organomet. Chem. 1977, 134, 189.

13. Dvorak, J.; O'Brien, R.J.; Santo W. J. Chem. Soc., Chem. Comm. 1970, 411.

${ }^{14}$. Erker, G.; Kropp, K. J. Am. Chem. Soc. 1979, 101, 3659.

15. Kropp, K.; Erker, G. Organometallics 1982, 1, 1246.

16. Erker, G.; Dorf, U.; Mynott, R.; Tsay, Y.H.; Krüger, C. Angew. Chem., Int. Ed. Eng. 1985, 24, 584. 
17. Buchwald, S.L.; Nielsen, R.B. Chem. Rev. 1988, 88, 1047.

18. Bennett, M.A.; Hambley, T.W.; Roberts, N.K.; Robertson, G.B. Organometallics 1985, 4, 1992 and references therein.

19. (a) Davidson, P.J.; Lappert, M.F.; Pearce, R. Chem. Rev. 1976, 76, 219.

(b) Schrock, R.R.; Parshall, G.W. ibid. 1976, 76, 243.

${ }^{20}$. Buchwald, S.l.; Watson, B.T.; Huffman, J.C. J. Am. Chem. Soc. 1986, 108, 7411.

${ }^{21}$. Buchwald, S.l.; Sayers, A.; Watson, B.T.; Dewan, J.C. Tetrahedron Lett. $1987,28,3245$.

22. (a) Hajela, S.; Bercaw, J.E. Organomettalics 1994, 13, 1147.

(b) Bunel, E.; Buerger, B.J.; Bercaw, J.E. J. Am. Chem. Soc. 1988, 110, 976.

(c) Shapiro, P.J.; Cotter, W.D.; Schaefer, W.P.; Labinger, J.A.; Bercaw, J.E. J. Am. Chem. Soc. 1994, 116, 4623.

(d) Shapiro, P.J.; Bunel, E.; Schaefer, W.P.; Bercaw, J.E. Organometallics 1990, 9, 867.

${ }^{23}$. Stevens, J.C.; Timmers, F.J.; Wilson, D.R.; Schmidt, G.F.; Nickias, P.N.;

Rosen, R.K.; Knight, G.W.; Lai, S. Eur. Pat. Appl. EP 416-815-A2, 1991.

24. (a) Canich, J.M. US Pat. Appl. 5026 798, 1991.

(b) Canich, J.M.; Hlatky, G.G.; Turner, H.W. Int. Pat. WO 92-00333, 1992.

(c) Cambell, R.E., Jr. US Pat. 5066 741, 1991.

25. (a) Okuda, J. Chem. Ber. 1990, 123, 1649.

(b) Okuda, J.; Schattenmann, F.J.; Wocadlo, S.; Massa, W. Organometallics 1995, 14, 789 .

26. (a) Chandra, G.; Lappert, M.F. J. Am. Chem. Soc. 1968, A, 1940.

(b) Lappert, M.F.; Power, P.B.; Sanger, A.R.; Srivastiva, R.C. Metal and Amines, Ellis Horwood: Chichester, West Sussex, U.K., 1980.

27. Hughes, A.K.; Meetsma, A.; Tueben, J.H. Organometallics 1993, 12, 1936.

28. Hermann, W.A.; Morawietz, M.J.A. J. Oganomet. Chem. 1994, 482, 169.

29. Carpenetti, D.W.; Kloppenburg, L.; Kupec, J.T.; Petersen, J.L.

Organometallics 1996, 15, 1572.

${ }^{30}$. Dreier, T.; Petersen, J.L., unpublished results. 
${ }^{31}$. Gordon, A.J.; Ford, R.A. "The Chemists Companion", Wiley-Interscience, New York, 1972.

32. Setukowski, D.G.; Stucky, G.D. Inorg. Chem. 1975, 14, 2192.

33. Manzer, L.E. Inorg. Synthesis 1982, 21, 134.

${ }^{34}$. King, R.B. “Organometallic Synthesis”, Acedemic Press, New York, 1965, Vol. 1.

${ }^{35}$. Fendrick, C.M.; Schertz, L.D.; Day, V.W.; Marks, T.J. Organometalics 1988, 7, 1828.

36. XSCANS (version 2.0) is a diffractometer control system developed by Siemens Analytical X-ray Instruments, Madison, WI.

37. SHELXL-93 is a FORTRAN-77 program (Professor G. Sheldrick, Institute für Anorganische Chemie, University of Göttingen, D-37077, Göttingen, Germany) for single crystal X-ray structural analyses.

38. The discrepancy indices were calculated fromn the expressions $\mathrm{R} 1=$ $\sum|| F_{\mathrm{O}}|-| \mathrm{F}_{\mathrm{C}}|| / \sum\left|\mathrm{F}_{\mathrm{O}}\right|$ and $\mathrm{wR} 2=\left[\sum\left(\mathrm{w}_{\mathrm{i}}\left(\mathrm{F}_{\mathrm{O}}{ }^{2}-\mathrm{F}_{\mathrm{C}}{ }^{2}\right)^{2}\right)\right]^{1 / 2}$ and the standard deviation of an observation of a unit weight $(\mathrm{GOF})$ is equal to $\left[\sum\left(\mathrm{w}_{\mathrm{i}}\left(\mathrm{F}_{\mathrm{O}}{ }^{2}\right.\right.\right.$ $\left.\left.\left.\mathrm{F}_{\mathrm{C}^{2}}\right)^{2}\right) /(\mathrm{n}-\mathrm{p})\right]^{1 / 2}$, where $\mathrm{n}$ is the number of reflections and $\mathrm{p}$ is the number of parameters varied during the last refinement cycle.

39. Atwood, J.L.; Hunter, W.E.; Alt, H.; Rausch, M.D. J. Am. Chem. Soc. 1976, 98, 2454. 


\begin{abstract}
Upon thermolysis in aromatic solvents, diarylzirconacenes and diaryltitanocenes form benzyne intermediates. Formation of the benzyne intermediate presumably occurs via $\mathrm{H}$-atom abstraction of an ortho- $\mathrm{H}$ of an aryl ligand by the adjacent $\sigma$-bonded aryl ligand to give the benzyne intermediate. The diphenylzirconocene benzyne intermediate can be stabilized by the addition of $\mathrm{PMe}_{3}$ to afford the $\mathrm{PMe}_{3}$ adduct which has been isolated and structurally characterized. This benzyne intermediate couples with a variety of unsaturated organic fragments including nitriles, alkenes, and acetylenes to form metallacyclic species and has found applications in organic synthesis. This benzyne also couples with tungsten hexacarbonyl to afford a Fischer-type metalloxycarbene complex.

Procedures for making the diphenyl precursors $\left[\left(\mathrm{C}_{5} \mathrm{R}_{4}\right) \mathrm{SiMe}_{2}(\mathrm{~N}-\mathrm{t}-\right.$ $\mathrm{Bu})] \mathrm{M}\left(\mathrm{C}_{6} \mathrm{H}_{5}\right)_{2}(\mathrm{R}=\mathrm{H}, \mathrm{Me} ; \mathrm{M}=\mathrm{Ti}, \mathrm{Zr})$ were developed. Separate coupling reactions involving two of the diphenyl precursors $\left[\left(\mathrm{C}_{5} \mathrm{H}_{4}\right) \mathrm{SiMe}_{2}(\mathrm{~N}-\mathrm{t}\right.$ $\mathrm{Bu})] \mathrm{Ti}\left(\mathrm{C}_{6} \mathrm{H}_{5}\right)_{2}$ and $\left[\left(\mathrm{C}_{5} \mathrm{Me}_{4}\right) \mathrm{SiMe}_{2}(\mathrm{~N}-\mathrm{t}-\mathrm{Bu})\right] \mathrm{Zr}\left(\mathrm{C}_{6} \mathrm{H}_{5}\right)_{2}$, with diphenylacetylene affords $\left[\left(\mathrm{C}_{5} \mathrm{H}_{4}\right) \mathrm{SiMe}_{2}(\mathrm{~N}-\mathrm{t}-\mathrm{Bu})\right] \mathrm{Ti}\left[\left(\mathrm{C}_{6} \mathrm{H}_{4}\right) \mathrm{C}(\mathrm{Ph})=\mathrm{C}(\mathrm{Ph})\right]$ and $\left[\left(\mathrm{C}_{5} \mathrm{Me}_{4}\right) \mathrm{SiMe}_{2}(\mathrm{~N}-\mathrm{t}-\right.$ $\mathrm{Bu})] \mathrm{Zr}\left[\left(\mathrm{C}_{6} \mathrm{H}_{4}\right) \mathrm{C}(\mathrm{Ph})=\mathrm{C}(\mathrm{Ph})\right]$, respectively. These compounds have been characterized by ${ }^{1} \mathrm{H}$ and ${ }^{13} \mathrm{C}$ NMR along with $2 \mathrm{D}$ COSY and HETCOR NMR measurements. The structure of $\left[\left(\mathrm{C}_{5} \mathrm{H}_{4}\right) \mathrm{SiMe}_{2}(\mathrm{~N}-\mathrm{t}-\mathrm{Bu})\right] \mathrm{Ti}\left[\left(\mathrm{C}_{6} \mathrm{H}_{4}\right) \mathrm{C}(\mathrm{Ph})=\mathrm{C}(\mathrm{Ph})\right]$ was also verified through X-ray structural analysis.

Comparison of the molecular structure to that of $\left.\mathrm{CpTi}\left(\mathrm{C}_{4}\right) \mathrm{Ph}\right)_{4}$ ) reveals the two inequivalant bonds are considerably shorter than the two Ti-C bonds of $\left.\left.\mathrm{CpTi}\left(\mathrm{C}_{4}\right) \mathrm{Ph}\right)_{4}\right)$ in the literature. This difference can be attributed to the presence of the bifunctional ansa-monocyclopentadienyl ligand resulting in an increased electrophilicity of the $\mathrm{d}^{0} \mathrm{Ti}(\mathrm{IV})$ metal center.
\end{abstract}




\section{Vita}

The author is the son of Mr. and Mrs. R.A. Nettles, Sr. and was born on October 21, 1973 in Wheeling, West Virginia. He lived his entire childhood in nearby Benwood, West Virginia and graduated from Bishop Donahue Memorial High School, McMechen, West Virginia, in 1991. He received a Bachelor of Science degree in Chemistry from Wheeling Jesuit College, Wheeling, West Virginia in May 1995. He is currently a graduate student in the department of Chemistry at West Virginia University, Morgantown, West Virginia, where he is a candidate for the degree of Master of Science. 
Approval of the Examining Committee

SYNTHESIS AND CHARACTERIZATION OF ELECTROPHILIC GROUP 4 METAL COMPLEXES OF BENZYNES

\section{By}

Shawn M. Nettles

\section{THESIS}

Submitted to

The College of Arts and Sciences

at

West Virginia University

in partial fulfillment of the requirements

for the degree of

Master of Science

in

Chemistry

Robert S. Nakon, Ph.D.

Björn C. Söderberg, Ph.D.

Date

Jeffrey L. Petersen, PhD., Chairman 


\title{
SYNTHESIS AND CHARACTERIZATION OF ELECTROPHILIC GROUP 4 METAL COMPLEXES OF BENZYNES
}

\section{By}

Shawn M. Nettles

\author{
THESIS \\ Submitted to \\ The College of Arts and Sciences \\ at \\ West Virginia University \\ in partial fulfillment of the requirements \\ for the degree of \\ Master of Science \\ in \\ Chemistry
}

Department of Chemistry

Morgantown, West Virginia

1998

Keywords: Benzynes, Metallacycles, Titanium, Zirconium 


\begin{abstract}
Upon thermolysis in aromatic solvents, diarylzirconacenes and diaryltitanocenes form benzyne intermediates. Formation of the benzyne intermediate presumably occurs via $\mathrm{H}$-atom abstraction of an ortho- $\mathrm{H}$ of an aryl ligand by the adjacent $\sigma$-bonded aryl ligand to give the benzyne intermediate. The diphenylzirconocene benzyne intermediate can be stabilized by the addition of $\mathrm{PMe}_{3}$ to afford the $\mathrm{PMe}_{3}$ adduct which has been isolated and structurally characterized. This benzyne intermediate couples with a variety of unsaturated organic fragments including nitriles, alkenes, and acetylenes to form metallacyclic species and has found applications in organic synthesis. This benzyne also couples with tungsten hexacarbonyl to afford a Fischer-type metalloxycarbene complex.

Procedures for making the diphenyl precursors $\left[\left(\mathrm{C}_{5} \mathrm{R}_{4}\right) \mathrm{SiMe}_{2}(\mathrm{~N}-\mathrm{t}-\right.$ $\mathrm{Bu})] \mathrm{M}\left(\mathrm{C}_{6} \mathrm{H}_{5}\right)_{2}(\mathrm{R}=\mathrm{H}, \mathrm{Me} ; \mathrm{M}=\mathrm{Ti}, \mathrm{Zr})$ were developed. Separate coupling reactions involving two of the diphenyl precursors $\left[\left(\mathrm{C}_{5} \mathrm{H}_{4}\right) \mathrm{SiMe}_{2}(\mathrm{~N}-\mathrm{t}\right.$ $\mathrm{Bu})] \mathrm{Ti}\left(\mathrm{C}_{6} \mathrm{H}_{5}\right)_{2}$ and $\left[\left(\mathrm{C}_{5} \mathrm{Me}_{4}\right) \mathrm{SiMe}_{2}(\mathrm{~N}-\mathrm{t}-\mathrm{Bu})\right] \mathrm{Zr}\left(\mathrm{C}_{6} \mathrm{H}_{5}\right)_{2}$, with diphenylacetylene affords $\left[\left(\mathrm{C}_{5} \mathrm{H}_{4}\right) \mathrm{SiMe}_{2}(\mathrm{~N}-\mathrm{t}-\mathrm{Bu})\right] \mathrm{Ti}\left[\left(\mathrm{C}_{6} \mathrm{H}_{4}\right) \mathrm{C}(\mathrm{Ph})=\mathrm{C}(\mathrm{Ph})\right]$ and $\left[\left(\mathrm{C}_{5} \mathrm{Me}_{4}\right) \mathrm{SiMe}_{2}(\mathrm{~N}-\mathrm{t}-\right.$ $\mathrm{Bu})] \mathrm{Zr}\left[\left(\mathrm{C}_{6} \mathrm{H}_{4}\right) \mathrm{C}(\mathrm{Ph})=\mathrm{C}(\mathrm{Ph})\right]$, respectively. These compounds have been characterized by ${ }^{1} \mathrm{H}$ and ${ }^{13} \mathrm{C}$ NMR along with $2 \mathrm{D}$ COSY and HETCOR NMR measurements. The structure of $\left[\left(\mathrm{C}_{5} \mathrm{H}_{4}\right) \mathrm{SiMe}_{2}(\mathrm{~N}-\mathrm{t}-\mathrm{Bu})\right] \mathrm{Ti}\left[\left(\mathrm{C}_{6} \mathrm{H}_{4}\right) \mathrm{C}(\mathrm{Ph})=\mathrm{C}(\mathrm{Ph})\right]$ was also verified through X-ray structural analysis.

Comparison of the molecular structure to that of $\left.\mathrm{CpTi}\left(\mathrm{C}_{4}\right) \mathrm{Ph}\right)_{4}$ ) reveals the two inequivalant bonds are considerably shorter than the two Ti-C bonds of $\left.\left.\mathrm{CpTi}\left(\mathrm{C}_{4}\right) \mathrm{Ph}\right)_{4}\right)$ in the literature. This difference can be attributed to the presence of the bifunctional ansa-monocyclopentadienyl ligand resulting in an increased electrophilicity of the $\mathrm{d}^{0} \mathrm{Ti}(\mathrm{IV})$ metal center.
\end{abstract}

